
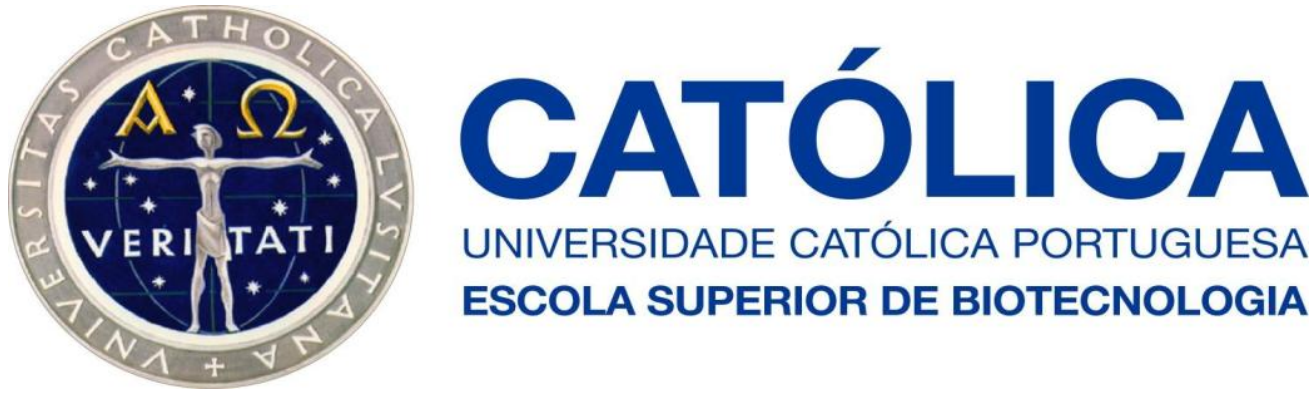

UNIVERSIDADE CATÓLICA PORTUGUESA ESCOLA SUPERIOR DE BIOTECNOLOGIA

\title{
FOOD SAFETY IN THE DOMESTIC ENVIRONMENT
}

Thesis presented to Escola Superior de Biotecnologia of the Universidade Católica Portuguesa to fulfil the requirements of Master of Science degree in Food Innovation

By Inês Gonçalves de Azevedo Moreira

(June, 2012) 

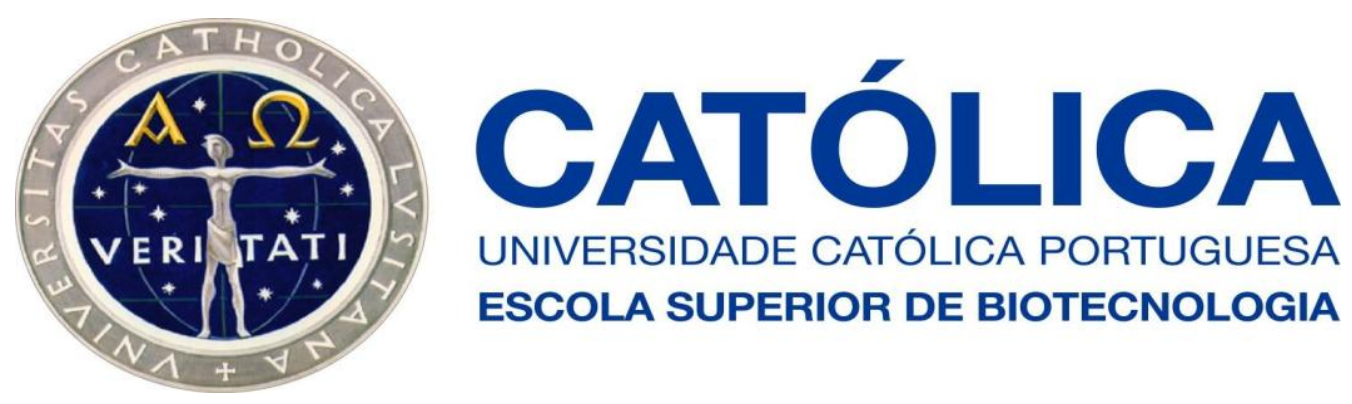

UNIVERSIDADE CATÓLICA PORTUGUESA ESCOLA SUPERIOR DE BIOTECNOLOGIA

\section{FOOD SAFETY IN THE DOMESTIC ENVIRONMENT}

Thesis presented to Escola Superior de Biotecnologia of the Universidade Católica Portuguesa to fulfil the requirements of Master of Science degree in Food Innovation

By Inês Gonçalves de Azevedo Moreira

Under the supervision of Prof. Doutora Paula Cristina Maia Teixeira

and

Doutora Joana Gabriela Laranjeira da Silva

(June, 2012) 


\section{Resumo}

O principal objetivo deste estudo foi avaliar a importância da segurança alimentar em ambientes domésticos.

A prevalência e identificação de bactérias de origem alimentar foi levada a cabo através da recolha de amostras em várias localizações de 15 casas, tais como maçanetas de portas, puxadores do frigorífico e máquina de lavar louça, botões de fogão, superfícies de preparação de alimentos, torneiras e toalhas de cozinha, bem como das patas de animais domésticos que usualmente têm acesso à área da cozinha, e ainda puxadores e torneiras de WC.

Um questionário foi também preparado e efetuado ao responsável pelas tarefas domésticas de modo a avaliar a experiência em práticas de higiene alimentar.

A deteção e quantificação de microrganismos de origem alimentar foram realizadas de acordo com os métodos descritos na International Standards Organization (ISO), resultando num total de 125 isolados de Enterobacteriaceae spp. (19 isolados de Salmonella spp., 46 de Escherichia coli e 60 de outras Enterobacteriaceae), 86 de Staphylococcus coagulase-positive, 5 de Listeria spp. e 13 de Escherichia coli. No entanto, nas 175 amostras analisadas não foi detetado Campylobacter spp..

A resistência aos antibióticos ampicilina, cloranfenicol, ciprofloxacina, gentamicina, ácido nalidíxico, tetraciclina, trimetropin e nitrofurantoína foi avaliada nos 3 grandes grupos dos 125 isolados de Enterobacteriaceae spp. (19 isolados de Salmonella spp., 46 de Escherichia coli e 60 de outras Enterobacteriaceae).

Escherichia coli e Salmonella spp. demonstraram resistência à ampicilina, cloranfenicol, tetraciclina, ácido nalidíxico e nitrofurantoína, enquanto outras Enterobacteriaceae apresentaram resistência apenas à ampicilina, trimetropin e nitrofurantoína. Resistência múltipla aos antibióticos descritos ocorreu maioritariamente nos isolados de Escherichia coli mas também em isolados de Salmonella spp. e de outras Enterobacteriaceae; no entanto, todos os isolados mostraram sensibilidade a antibióticos de grande importância clínica, como as fluoroquinolonas e os aminoglicosídeos. 


\section{Abstract}

The main purpose of the work was to evaluate the significance of food safety in domestic environments.

The prevalence and identification of food-borne pathogens were assessed by taking swabs from several points in 15 houses, such as knobs of doors, refrigerators and dishwashers, stove buttons, surfaces of preparation of foods, taps and kitchen towels, as well as from domestic animals' feet that usually have access to the kitchen area, and WC knobs and taps.

A questionnaire was also prepared and administered to the person responsible for domestic tasks in order to evaluate their experience of hygienic practices.

Detection and quantification of food-borne microorganisms was made according to the methods described in the International Standards Organization (ISO), resulting in a total of 125 Enterobacteriaceae spp. isolates (19 Salmonella spp. isolates, 46 of Escherichia coli and 60 of other Enterobacteriaceae), 86 Staphylococcus coagulase-positive isolates, 5 Listeria spp. isolates and 13 Escherichia coli isolates. No Campylobacter spp. was found in the 175 analyzed samples.

Antibiotic resistance to ampicillin, chloramphenicol, ciprofloxacin, gentamicin, tetracycline, nalidixic acid and trimethoprim was evaluated in the 3 major groups of the 125 isolates of Enterobacteriaceae spp. (19 Salmonella spp. isolates, 46 of Escherichia coli and 60 of other Enterobacteriaceae). Escherichia coli and Salmonella spp. showed resistance to ampicillin, chloramphenicol, tetracycline, nalidixic acid and nitrofurantoin, while other Enterobacteriaceae presented resistance only to ampicillin, trimethoprim and nitrofurantoin. Multiple antibiotic resistance occurred mainly in Escherichia coli isolates but also in Salmonella spp. and other Enterobacteriaceae; nevertheless all the isolates showed sensitivity to antibiotics of clinical importance, such as fluoroquinolones and aminoglycosides. 


\section{Acknowledgements}

To Escola Superior de Biotecnologia de Universidade Católica Portuguesa for accepting me as M.Sc. student.

To my supervisor Prof. Doutora Paula Teixeira I want to present my special thanks. Thank you for this opportunity, for always being available and present in all those critical moments.

To Prof. Doutor Paul Gibbs, thank you for your help with this thesis correction and for all your wise comments about work and life.

To Doutora Joana Silva thank you so much for all the support and presence whenever I felt a little lost.

My true gratitude to all who worked and work in Laboratório de Bactérias Lácticas e Pescado, for all the fun and good mood that allowed me a much more healthy and cheerful work, and also for all experiences and advices transmitted, especially to Vânia Ferreira, Joana Barbosa, Helena Albano, Sandra Borges e Ana Carvalheira. I know that my work would not have been possible if you didn't light up my day and I felt blessed to work with so dear and good friends.

To Patrícia Carvalho, I am immeasurably grateful for her invaluable friendship, for all our long conversations and her wise advices, help in all developed work and in life.

To everyone who allowed me into their house I want to express my gratitude. Without you I would never be able to find all my precious "little bugs" for this work.

To all my good friends who were always "annoying" me to finish my thesis a big hug and a unique thank you for all the persistence and determination.

To my great friend Patrícia Pereira, I want to thank for believe in me and, above all, for given me strength all the time even when she is in weakness moments. I am thankful for you being by my side in so many moments, for your friendship, your advices, your care and precious friendship.

My grateful to António Cordeiro, for all that he had to pass through, for many hours listening to me complaining about everything and everyone... Thank you for being part of my life, for being you and for your everlasting love... thank you for all.

To my parents and brothers for everything they've always done and still do for me. I am grateful for all they have taught me, the good values and astute advices, and for always being "next door" in good and bad times... Thank you for making me a more rational and sensible human! 


\section{Table of contents}

Resumo

Abstract

Acknowledgements

1. Introduction

$\begin{array}{ll}\text { 1.1. Food Safety in the domestic environment } & 1\end{array}$

1.2. Antibiotic resistance in Enterobacteriaceae species 3

1.3. Food Safety survey: knowledge levels of consumers 4

1.4. Aims of the study $\quad 4$

2. Material and Methods $\quad 5$

2.1. Sampling $\quad 5$

2.2. Campylobacter spp. detection $\quad 5$

2.3. Coagulase-positive Staphylococcus enumeration $\quad 5$

2.4. Listeria monocytogenes detection $\quad 6$

2.5. Escherichia coli enumeration $\quad 6$

2.6. Enterobacteriaceae spp. 6

2.6.1. Enumeration and detection 6

2.6.2. Identification Tests $\quad 7$

2.6.2.1. Growth on MacConkey agar plates $\quad 7$

$\begin{array}{ll}\text { 2.6.2.2. Triple Sugar Iron test } & 7\end{array}$

2.6.2.3. Indole production from tryptophan 8

$\begin{array}{ll}\text { 2.7. Antibiotic susceptibility of Enterobacteriaceae } & 8\end{array}$

2.7.1. Minimal Inhibitory Concentration (MIC) estimation 8

2.8. Domestic survey 9

3. Results and Discussion $\quad 10$

3.1. Campylobacter spp. detection 10

3.2. Coagulase-positive Staphylococcus count 10

3.3. Listeria monocytogenes detection 11

3.4. Escherichia coli count 12

3.5. Enterobacteriaceae spp. count and detection 13

3.6. Enterobacteriaceae antibiotic resistance 19

3.7. Domestic survey 32

4. Conclusion $\quad 43$

5. Future work $\quad 45$

6. References $\quad 46$

Annex

Annex 1 - In vitro susceptibility house profiles of Enterobacteriaceae to several antibiotics 


\section{Introduction}

Every year, millions of people worldwide experience foodborne diseases and illnesses resulting from the consumption of contaminated food, which has become one of the most common public health problems in the contemporary world (Notermans et al., 1995; WHO, 2004).

Foodborne diseases impose a big burden on health and millions of people fall ill and many die as a result of eating unsafe food, so a resolution was adopted by WHO and its Member States to recognize food safety as an essential public health function, and to develop a Global Strategy for reducing the weight of foodborne diseases (WHO, 2002). In May 2010 the World Health Assembly approved a new resolution on food safety - Advancing Food Safety Initiatives (WHA, 2010) - of which the main goal is to update the current WHO Global Strategy for Food Safety (WHO, 2002).

The main purpose of this Master's thesis was to evaluate the significance of food safety in the domestic environment.

\subsection{Food Safety in the domestic environment}

Food safety is an important issue for consumers; they need to know how to safely prepare and handle food. Knowledge on safe food practices reduces consumer health risks from foodborne diseases that commonly result from poor food-handling and hygiene practices. These are thought to be the cause of a significant amount of foodborne illness, in the domestic environment (Scott, 1996; Fischer et al., 2006).

As consumers, we expect food to be harmless, tasty and nutritious. Yet, every year millions of people become ill as a result of eating contaminated food. In fact, the World Health Organization (WHO) estimates that approximately 10 to $30 \%$ of the population in developed countries experience food poisoning annually (WHO, 2007). From farm to fork, microorganisms are transferred to our food through contact with contaminated water, insects, animals, humans, other contaminated foods and air. Microorganisms are able to multiply in our food and sometimes to produce toxins during processing and storage. When foods are eaten, e.g. raw, undercooked or simply cross-contaminated after cooking, we can consume these bacteria and/or their toxins. They can progress into our intestines and invade the cells lining the gut and/or the blood stream and potentially every organ in our bodies (Bolton and Maunsell, 2006).

The expression "diseases of alimentary origin" is vulgar and traditionally used to designate a group of symptoms which include gastric disturbances, usually involving vomiting, diarrhoea, fevers and abdominal pains, that can occur individually or in combination (Pinto, 2007).

Many indicators show that foodborne diseases are increasing in the domestic environment, mostly due to inappropriate food handling preparation and storage by consumers in their own kitchens. The main problem is that home-based outbreaks are not often identified nor reported which understates the real situation (Scott, 1996; Fisher et al., 2006). 
It is difficult to estimate the global incidence of foodborne disease, but according to WHO (2007) around 1.8 million people died from diarrheal diseases, mostly due to contamination of food and drinking water. In the United States up to 76 million cases of foodborne diseases, resulting in 325,000 hospitalizations and 5,000 deaths, are estimated to occur every year. In developing countries, a wide range of foodborne illnesses is usually the biggest problem and the high prevalence of diarrheal diseases suggests major primary food safety problems. Although most foodborne diseases are sporadic and often not reported, foodborne disease outbreaks may take on massive proportions.

Foodborne diseases are commonly considered as one of the biggest problems of public health in most countries and the reduction of these diseases is one of the main goals in national and international food safety programmes. Poor food handling and hygiene practices in our homes seem to be a key element in the prevention of foodborne diseases (Noronha et al., 2006).

Because of its own nature, the domestic environment is a multifunctional place and this has a direct impact on the need for food safety improvement. First of all, the domestic environment contains occupants of assorted ages and diverse health status. Particularly, the emergent elderly and immunocompromised populations living at home are often at a higher risk for the acquisition of foodborne diseases as well as for a more severe disease outcome (Scott, 2003).

Consumers must know and be aware of the need for good hygiene practices at home to prevent the occurrence of infectious diseases. The biggest problems in achieving these improvements are educating the public and promoting behavioural changes. Inappropriate hand washing, food handling and preparation, short cooking times and long storage in non-appropriate conditions at home, can all permit proliferation of microorganisms. Pathogenic microorganisms are being carried to our homes through people, food, domestic animals, contaminated water and by air. These microorganisms are being disseminated to various surfaces throughout the home by cross-contamination, indicating the need for behavioural changes in our daily life (Gorman et al., 2002). Many consumers don't know that raw food is one of the sources of bacterial contamination in our kitchen. Even more, consumers are not aware that the human body carries lots of pathogenic microorganisms being the main source of cross-contamination during food handling and preparation (Scott, 1996). Additionally, to its human occupants, the home is often a shelter for pets. Domestic cats and dogs frequently serve as reservoirs for microorganisms and, thus, are potential sources of infection. These animals can transfer their intrinsic microflora to the kitchen food handling surfaces, increasing the risk of crosscontamination to food (Scott, 2003) .

Foods and microorganisms have long and healthy associations such as the nutritional significance and as an ideal culture media for microbial development. Microbial growth in foods can result in preservation or spoilage, depending on the microorganisms involved and food storage conditions. Microorganisms can be used to convert raw foods into gastronomic delights, including cheeses, pickles, sausages, wines, beers and other alcoholic beverages. On the other hand, foods also can act as a vehicle for disease transmission. During the entire sequence of food handling, from the producer to final consumer, microorganisms can affect food quality and human health. Contamination 
by disease causing microorganisms can occur at any point in the food handling sequence (Prescott et al., 1999).

Around the world in the near future, foodborne diseases will continue to be an issue of major concern. Public instruction can be seen as a key factor in the improvement of food safety practices at home and the benefits of food hygiene education would include a decrease in the occurrence of foodborne illness as well as a population better prepared to meet the needs for safer food (Scott, 2003).

\subsection{Antibiotic resistance in Enterobacteriaceae species}

The Enterobacteriaceae family is frequently used as an indicator of faecal contamination during food microbiological analyses, and contains important zoonotic bacteria such as Salmonella spp. and Escherichia coli. Enterobacteriaceae may originate severe infections, and unfortunately several of the most important members of this family are becoming progressively more resistant to currently available antimicrobials such as tetracyclines and fluoroquinolones (Fritsche et al., 2005; Paterson, 2006; Denton, 2007).

Nowadays, the antimicrobial agents used to treat or prevent bacterial infections in animals are basically the same classes of compounds that are used in human medicine. In both cases the use of antibiotics not only causes an increase of resistance in pathogenic bacteria, but also in the endogenous flora of these animals. These animals' resistant bacteria can infect or reach the human population not only by direct contact, but also via food products of animal origin (van den Bogaard and Stobberingh, 2000).

The choice of antibiotics becomes more limited, since the bacteria are also resistant to other drugs. For example, when established more than two decades ago, the fluoroquinolones, particularly ciprofloxacin, were considered the "new penicillins" because they were secure, bactericidal and exhibited a relatively broad spectrum of activity. Even though resistance to fluoroquinolones was not observed in this present study, over the past decade the emergence of high-level, fluoroquinolone resistance among Escherichia coli and other clinically important pathogens such as Staphylococcus aureus and Pseudomonas aeruginosa, has been witnessed (Piddock, 1999). Nevertheless, E. coli, the leading cause of urinary tract infection and Gram-negative bacteraemia, which was naturally susceptible to ampicillin, nowadays $50-60 \%$ of isolates present resistance worldwide (Wu et al., 1992).

This resistance phenomenon requires continual vigilance and measures have to be found in order to control the further spread of resistance by pathogens included in the Enterobacteriaceae family. Another aspect of concern is related to the increase in multi-resistance now common in both community and hospital isolates (Shannon and French, 2004). 
However, little information relative to enteric bacteria isolated from domestic settings is currently available. Consequently, a second main goal of the present study was to investigate the prevalence of antimicrobial susceptibility found in Enterobacteriaceae isolates found in the domestic environment and try to make a comparison with some other studies. The potential repercussion of these results in microbiological safety terms, especially concerning the development and spread of antimicrobial resistance to the food chain, will be discussed.

\subsection{Food Safety survey: knowledge levels of consumers}

Increasingly, food safety awareness levels are essential for food poisoning prevention. The main sources of infection in the domestic environment are people, pests, pets and contaminated food and water. Therefore home hygiene isn't just daily cleaning the house but also knowing how to prevent contamination. Microbes are constantly transmitted by direct contact with people or animals, through contaminated food, water, surfaces and air. When preparing contaminated food, pathogens easily spread onto cooking utensils, such as cutting boards and knives, or onto surfaces when using kitchen cloths (Beumer and Kusumaningrum, 2003).

Consumers need to know which behaviours are more likely to result in illness in order to make decisions about food handling and consumption behaviours, making education the main focus to reduce foodborne diseases (Jevsnik et al., 2008).

In this study it seemed important to design a questionnaire with some questions related with food safety and cleaning habits which was administered to the responsible persons in each house.

\subsection{Aims of the study}

In order to evaluate the significance of food safety in domestic environments, the prevalence and identification of food-borne pathogens were assessed by analysing several points in 15 houses and then several objectives were established:

- Estimate potential risks of cross contamination in the domestic environment;

- Evaluate the prevalence of some foodborne pathogens, namely Enterobacteriaceae spp., $E$. coli, S. aureus, L. monocytogenes and Campylobacter spp., at various defined points in different houses;

- Characterization of the presumptive Enterobacteriaceae spp. isolates in order to obtain representative groups according to their metabolic characteristics;

- Determine antibiotic susceptibility of Enterobacteriaceae isolates;

- Correlate the microbiological results obtained for each domestic environment with the results of the questionnaire applied at each house. 


\section{Material and Methods}

\subsection{Sampling}

During the period January 2008 to July 2008, the detection and/or enumeration of Enterobacteriaceae, coagulase-positive Staphylococcus, E. coli, L. monocytogenes and Campylobacter spp. in 15 different private homes was assessed by taking several cotton swabs from various defined points i.e. knobs of doors, refrigerators and dishwashers, stove buttons, surfaces used for preparation of foods, taps and kitchen towels, WC knobs and taps and from domestic animals' feet that usually have access to the kitchen area. Samples were taken after the normal daily cleaning of the house, then collected, stored in thermo bags and further analysed as soon as they arrived in the laboratory.

\subsection{Campylobacter spp. detection}

The detection of Campylobacter spp. was performed according to International Standard Organization (ISO) 10272-1 methodology. After sampling, cotton swabs were immediately inoculated in Bolton Broth (Biokar) and incubated at $37^{\circ} \mathrm{C}$ for 4 to 6 hours and subsequently at $41.5{ }^{\circ} \mathrm{C}$ for 44 hours in a microaerobic environment. Using the spread plate technique, $0.1 \mathrm{~mL}$ samples were inoculated onto modified Cefoperazone Charcoal Deoxycholate Agar (mCCDA, Oxoid) and incubated for 48 hours at $41.5^{\circ} \mathrm{C}$ under microaerobic conditions, using a specific incubator.

Characteristic colonies (gray, flat, with metallic shine and with swarming tendency) were selected and sub-cultured on Columbia agar with 5\% sheep blood (BioMérieux) and incubated between 24 to 48 hours at $41.5 \stackrel{\circ}{\circ}$ under microaerobic conditions. After this period characteristic colonies were confirmed through direct microbiologic examination, oxidase test and growth on blood agar under aerobic and microaerobic conditions during 44 hours at $41.5^{\circ} \mathrm{C}$. Small curved bacilli, with rapid motility, corkscrew shape, oxidase positive and that do not grow under aerobic conditions at $41.5 \stackrel{\circ}{\circ} \mathrm{C}$ were incubated on Tryptic soy agar (TSA, Biokar), for 24 hours at $37^{\circ} \mathrm{C}$ and then stored, in triplicate, at - $80{ }^{\circ} \mathrm{C}$ in Trypticase Soy Broth (TSB, Pronadisa-Conda Lab) containing 30\% (v/v) of glycerol (Sigma).

\subsection{Coagulase-positive Staphylococcus enumeration}

The enumeration of coagulase-positive Staphylococcus was performed according to the ISO 6888-1 methodology.

After sampling, cotton swabs were immediately inoculated in $10 \mathrm{~mL}$ of Buffered Peptone Water (BPW, Oxoid). Decimal dilutions were prepared with sterile Ringer's solution (Lab M) and enumeration was performed by the spread plate technique on Baird Parker Agar (BPA, Biokar Diagnostic) with egg yolk (Bio-Rad) $(0.5 \mathrm{~mL}$ from the initial suspension, in duplicate, and $0.1 \mathrm{~mL}$ of each dilution) and further incubated at $37^{\circ} \mathrm{C}$ for 48 hours.

Characteristic (with an opaque halo surrounded by a zone of clearing) and non-characteristic black colonies were counted and from each plate, five characteristic and five non-characteristic colonies were selected and then sub-cultured in Brain Heart Infusion broth (BHI, Merck), for 24 hours at $37^{\circ} \mathrm{C}$. 
Coagulase test was performed by adding $150 \mu \mathrm{L}$ of the $\mathrm{BHI}$ suspension to $250 \mu \mathrm{L}$ of rabbit plasma (Biokar Diagnostic) and incubating for approximately 12 hours at $37^{\circ} \mathrm{C}$. S. aureus and $S$. epidermidis were used as positive and negative controls, respectively. All coagulase positive colonies (gelling of the plasma) were isolated on TSA, incubated for 24 hours at $37^{\circ} \mathrm{C}$ and then stored, in triplicate, at - $80 \stackrel{\circ}{\circ}$ in TSB containing $30 \%(\mathrm{v} / \mathrm{v})$ of glycerol.

\subsection{Listeria monocytogenes detection}

The detection of L. monocytogenes was performed according to the ISO 11290-1 methodology.

After sampling, cotton swabs were transferred to $10 \mathrm{~mL}$ of half-Fraser broth (Biokar Diagnostics) and incubated at $30 \stackrel{\circ}{\circ} \mathrm{C}$ for $48 \mathrm{~h}$. Aliquots $(1 \mathrm{~mL})$ of these primary enrichments were transferred to $10 \mathrm{~mL}$ of secondary enrichment Fraser broth (Biokar Diagnostics) and incubated at $30{ }^{\circ} \mathrm{C}$ for $48 \mathrm{~h}$. A loopful of each primary enrichment culture and of the secondary enrichments after 24 and 48 hours of incubation, were streaked separately onto PALCAM (Merck) and ALOA (BioMérieux) agar plates. Characteristic colonies (blue/green with an opaque halo in ALOA and green/gray with black precipitate in PALCAM) were selected after incubation at $37^{\circ} \mathrm{C}$ for 48 hours, five typical colonies per plate (when possible) were transferred onto PALCAM Agar, incubated at $37^{\circ} \mathrm{C}$ for 48 hours.

Pure cultures were tested for sugars fermentation, mannitol $(0.5 \% \mathrm{w} / \mathrm{v})$, rhamnose $(1 \% \mathrm{w} / \mathrm{v})$ and xylose $(0.5 \% \mathrm{w} / \mathrm{v})$ and CAMP with S. aureus NCTC 1621 and Rhodococcus equi NCTC 25923. L. monocytogenes positive colonies were then stored, in triplicate, at - $80 \stackrel{\circ}{\circ} \mathrm{C}$ in TSB containing $30 \%(\mathrm{v} / \mathrm{v})$ of glycerol.

\subsection{Escherichia coli enumeration}

The enumeration of E. coli was performed according to the ISO 16649-2 methodology. After sampling, cotton swabs were immediately inoculated in $10 \mathrm{~mL}$ of BPW. Decimal dilutions were prepared with sterile Ringer's solution and enumeration was performed by the pour plate technique $(1 \mathrm{~mL}$ of each dilution) in Tryptone Bile X-glucuronide Agar (TBX, Bio-Rad). The plates were further incubated at $44 \stackrel{\circ}{\mathrm{C}}$ for 48 hours.

Characteristic blue/green colonies were counted and from each plate, five different colonies were selected, sub-cultured in TSA, for 24 hours at $37^{\circ} \mathrm{C}$ and then stored, in triplicate, at - $80{ }^{\circ} \mathrm{C}$ in TSB containing $30 \%(\mathrm{v} / \mathrm{v})$ of glycerol.

\subsection{Enterobacteriaceae spp.}

\subsubsection{Enumeration and detection}

The enumeration and detection of Enterobacteriaceae were performed according to the ISO 21528-2 methodology.

After sampling, cotton swabs were immediately inoculated into $10 \mathrm{~mL}$ of BPW. Decimal dilutions were prepared with sterile Ringer's solution and enumeration was performed by the pour plate technique in Violet Red Bile Glucose Agar (VRBGA, Biokar Diagnostic) (1 mL of each dilution plus 
overlay). Plates were then incubated at $37^{\circ} \mathrm{C}$ for 24 hours. Simultaneously, the detection of Enterobacteriaceae as described for the enumeration but with the inclusion of an enrichment step in BPW for 24 hours at $37^{\circ} \mathrm{C}$ before the enumeration.

In both cases, characteristic red colonies were counted. From each plate, five individual colonies were randomly selected and then sub-cultured in TSA, for 24 hours at $37^{\circ} \mathrm{C}$. Confirmation of isolates was performed according to the results obtained for the glucose fermentation and for the oxidase positive test. Presumptive Enterobacteriaceae, glucose fermenting and oxidase negative isolates, were then stored, in triplicate, at - $80^{\circ} \mathrm{C}$ in TSB with $30 \%(\mathrm{v} / \mathrm{v})$ of glycerol.

\subsubsection{Identification Tests}

Different tests were performed in order to confirm the identification of the isolates to the family level and to group them on the basis of specific biochemical characteristics. Controls and working cultures were recovered from frozen storage in TSB for 24 hours at $37^{\circ} \mathrm{C}$ and then inoculated onto TSA (incubated at $37^{\circ} \mathrm{C}$ for 24 hours). All controls used in identification tests are part of ESB culture collection.

\subsubsection{Growth on MacConkey agar plates}

MacConkey agar medium (Merck) is selective for Gram negative bacteria and can differentiate those bacteria that are able to ferment lactose. Isolated colonies of presumptive Enterobacteriaceae grown on TSA were streaked on the surface of MacConkey agar plates and further incubated for 18 to 24 hours at $37^{\circ} \mathrm{C}$. Salmonella spp. were used as a negative control, colonies of non-lactose fermenting organisms are colourless. E. coli was used as a positive control - colonies of lactose fermenting organisms are red and surrounded by a turbid zone due to the precipitation of bile acids as a result of acid $\mathrm{pH}$.

\subsubsection{Triple Sugar Iron test}

A colony of presumptive Enterobacteriaceae grown in TSA was inoculated onto Triple Sugar Iron (TSI) slants and incubated for $24 \mathrm{~h}$ at $37^{\circ} \mathrm{C}$. This medium was used to observe the degree of acid produced and to differentiate between non-fermenters, glucosefermenters (which produce a relatively small amount of acid) and those which ferment lactose and/or sucrose in addition to glucose (producing a relatively large amount of acid which diffuses throughout the medium). Organisms which produce hydrogen sulfide from the reduction of thiosulfate are easily detected because the $\mathrm{H}_{2} \mathrm{~S}$ reacts with the iron in the medium to produce ferrous sulfide, a black precipitate. Five controls were used, namely Klebsiella spp. Salmonella spp., E. coli, Proteus vulgaris, and a negative without inoculum. In the case of Klebsiella spp. the TSI tube became yellow with some cracks because it ferments all three sugars producing gas. For Salmonella spp. the butt of the tube presented 
a black cracked precipitate indicating glucose fermentation with gas and $\mathrm{H}_{2} \mathrm{~S}$ production but the slant colour is red because only glucose is fermented and the bacterium is capable of utilizing and fermenting glucose, but not lactose or sucrose. E. coli fermented all sugars with gas formation and that's why the tube presented a yellow colour with big cracks. Proteus vulgaris fermented all three sugars with gas and $\mathrm{H}_{2} \mathrm{~S}$ formation (yellow with a black precipitate colour with cracks). The non-inoculated tube remained red, the characteristic colour of the original medium.

\subsubsection{Indole production from tryptophan}

The indole test determines the ability of an organism to produce indole from the degradation of the amino acid tryptophan, which is hydrolyzed by tryptophanase to produce three possible end products, one of which is indole. BPW was inoculated with one isolated colony grown in TSA and further incubated at $37^{\circ} \mathrm{C}$ for 24 to 28 hours. After this period $0.5 \mathrm{~mL}$ of Kovac's reagent (Merck) was gently added. The presence of a red or red-violet colour in the surface alcohol layer of the broth was considered a positive result. A negative result appeared yellow. E. coli and Salmonella spp were used as positive and negative controls, respectively.

\subsection{Antibiotic susceptibility of Enterobacteriaceae spp.}

\subsubsection{Minimal Inhibitory Concentration (MIC) estimation}

For each isolate, the minimum inhibitory concentration MIC $(\mu \mathrm{g} / \mathrm{mL})$ of eight antibiotics was determined by the agar microdilution method, according to the Clinical and Laboratory Standards Institute (CLSI, 2007). Antibiotics were chosen on the basis of their ability to provide a diverse representation of different classes of antimicrobial agents.

Each test was carried out on Muller-Hinton Agar (MHA) (BioMérieux) with cation adjusted for ampicillin (AMP) (Fluka) and on MHA for the seven other tested antibiotics - ciprofloxacin (CIP), chloramphenicol ( $\mathrm{CHL}$ ), gentamicin (GEN), nalidixic acid (NAL), nitrofurantoin (NIT), tetracycline (TET) and trimethoprim (TMP) (kindly supplied by the company Labesfal, Portugal). With the exception of TMP ranging from 0.0156 to $128 \mu \mathrm{g} / \mathrm{mL}$; all the other antibiotic concentrations ranged from 0.0156 to $512 \mu \mathrm{g} / \mathrm{mL}$. Inocula were prepared from overnight cultures on TSA plates, by suspension in sterile Ringer's solution in order to obtain turbidity equivalent to 0.5 McFarland standards. Approximately $1 \mu \mathrm{L}$ was positioned on each plate containing antibiotic with an automatic plating system (Mast Group, Ltd.). All isolates were grown in plates of MHA and MHA with cation adjusted with no antibiotic. The quality control strains Enterococcus faecalis ATCC 29212 and E. coli ATCC 25922 were used to monitor the accuracy of MICs (CLSI, 2007). Plates were incubated for 24 hours at $37^{\circ} \mathrm{C}$. Classification of isolates according to their susceptibility (as sensitive, intermediate or resistant) was based on the values recommended by the CLSI (2007; Table 2A - MIC Interpretative 
Standards $(\mu \mathrm{g} / \mathrm{mL})$ for Enterobacteriaceae). Isolates exhibiting resistance to at least two of the antimicrobial agents were considered to be multi-resistant strains.

\subsection{Domestic survey}

A questionnaire was designed and some questions related with food safety and cleaning habits were administered to the responsible persons in each house.

This questionnaire included the following questions:

- Is there any domestic animal in your house?

- Does your pet stay inside, outside your house or both?

- When it's inside your house does it stay in the kitchen area?

- What kind of pet do you possess? A cat, a dog or something else?

- If you own a cat, what sort of sand do you buy?

- When you use WC do you wash your hands always, most of times, rarely or never?

- In the kitchen area do you usually wash your hands when you go to WC, handle raw, cooked or ready to eat food?

- How often do you normally clean door knobs?

- Do you use detergent, disinfectant, water or something else for knobs cleaning?

- How often do you normally clean kitchen taps?

- Do you use detergent, disinfectant, water or something else for taps cleaning?

- How often do you normally clean kitchen counter?

- Do you use detergent, disinfectant, water or something else for kitchen counter cleaning?

- How often do you normally clean kitchen stove buttons?

- Do you use detergent, disinfectant, water or something else for kitchen stove buttons cleaning?

- How often do you normally clean the dishwasher knob?

- Do you use detergent, disinfectant, water or something else for dishwasher knob cleaning?

- How often do you normally clean the refrigerator knob?

- Do you use detergent, disinfectant, water or something else for refrigerator knob cleaning?

- Do you use kitchen cloths?

- Do you use wood or plastic cutting board?

- Do you have different cutting boards for vegetables, meat, fish, cooked and raw food?

- Do you have any kind of doubt about proper food safety behaviours?

All the data was evaluated and combined, using Excel, in order to obtain comparative results between different houses and surfaces. 


\section{Results and Discussion}

Increasingly, food safety awareness levels are essential for preventing food poisoning. Domestic environment is frequently contaminated by people, pests, pets, food and water and daily cleaning the home hygiene may not be enough therefore it is rather important to know how to prevent contamination. Taking this into consideration, in this section, all the results obtained from the domestic setting will be presented and discussed.

\subsection{Campylobacter spp. detection}

Although Campylobacter is often present in domestic environments when high risk foods, like chicken, are prepared in domestic kitchens, resulting in cross contamination (Humphrey et al., 2001), this bacteria was not detected in any of the 15 houses sampled in this study. This agrees with the results of Speirs et al. (1995), who also failed to identify this pathogen in a large variety of sites examined in 46 domestic kitchens.

These bacteria are generally sensitive to the extra-intestinal environment and conditions common in kitchens, such as high or low temperature and drying environment, that may not only cause a reduction in the viable population, but also injure surviving cells. There is much to be learned about Campylobacter behaviour, and particularly about the best methods for their isolation from non-clinical samples. Usually Campylobacter can take a very long time to repair cellular damage and begin to grow, which can result in some false negative results being obtained (Humphrey et al., 2001).

\subsection{Coagulase-positive Staphylococcus count}

A total of eighty six samples of coagulase-positive Staphylococcus were collected from all places in all 15 houses analysed. As can be seen in Figure 1, the greatest numbers were detected from the feet of domestic animals, WC tap and knob, kitchen counter, cooking stove buttons, refrigerator and dishwasher handles. According to some authors it is quite common to find $S$. aureus in domestic environments since it is a common inhabitant of the human nose, throat and skin (Arbuthnott et al., 1990) and therefore more likely to contaminate foods by direct or indirect human contact during domestic food handling (Kusumaningrum et al., 2003). This microorganism can survive for between 2 and 4 days on surfaces, and is easily transferred from such sites to food by a range of mechanisms (Kusumaningrum et al., 2003). S. aureus is also commonly found in a wide range of food products such as meat, cheese and milk and from environmental sources such as soil, air and water (Kloos and Schleifer, 1986).

Domestic animals analysed in this study, both canine and feline species, demonstrated high carrier rates of coagulase-positive Staphylococcus on their feet, which is considered normal since they are usually found inside and outside of the house. These animals may possibly serve as a source of 
pathogenic staphylococci, since the rates isolated are indicative of a potential reservoir of pathogenic organisms (Morrison et al., 1961).

Up to $39 \%$ of domestic food poisoning outbreaks are due to food preparers' hands (Ryan et al., 1996) and therefore all sites which are directly contacted by fingers, are potentially contaminated. Places like taps, knobs, stove buttons, kitchen counter and handles (refrigerator and dishwasher) were shown to carry high counts since cross-contamination to other surfaces by hands, occurs easily. Many studies have noted the ability of pre-inoculated foods to cause cross-contamination of other surfaces and sites in the domestic kitchen (de Wit et al., 1979; de Boer and Hahné, 1990; Scott and Bloomfield, 1990; Bradford et al., 1997; Zhao et al., 1998), thereby identifying the ability of foodborne disease microorganisms to become disseminated from naturally contaminated foods to various hand and food contact surfaces in the domestic kitchen.

\subsection{Listeria monocytogenes detection}

Since Listeria spp. are commonly found in the general environment (Beumer et al., 1996; Azevedo et al., 2005), the presence of these organisms in the domestic environment is not surprising. Several food products have been associated with Listeria contamination, such as milk and dairy products, various meats and meat products such as beef, pork, fermented sausages, fresh produce such as radishes, cabbage, seafood and fish products (Gadhi and Chikindas, 2007). Through cross contamination this pathogen can spread, adapt to survive and grow in a wide range of environmental conditions.

In this study Listeria spp. were present in low numbers and only on five of the 11 sites analysed (Figure 2). L. monocytogenes was not isolated from any of the samples, however $L$. seeligeri, $L$. innocua and L. grayi were found in the WC (tap and knob), kitchen tap and kitchen counter, respectively (Table 1).

Azevedo et al. (2005) found that $L$. monocytogenes was present in three domestic refrigerators out of the 86 investigated and L. grayi and L. innocua were also isolated from four and one refrigerators, respectively. This may indicate that these pathogens may normally exist in our kitchen, although apparently at low numbers and frequency.

Table 1 - Occurrence of Listeria spp. in the domestic environment.

\begin{tabular}{ccc} 
Type of sample (Number) & Listeria number present (\%) & Isolated Listeria spp. \\
\hline Domestic Animal (30) & $1(3.3)$ & 1 (Listeria spp.) \\
WC Tap (15) & $1(6.7)$ & 1 (Listeria seeligerı) \\
WC Knob (15) & $1(6.7)$ & 1 (Listeria seeligeri) \\
Kitchen Tap (15) & $1(6.7)$ & 1 (Listeria innocua) \\
Kitchen Counter (15) & $1(6.7)$ & 1 (Listeria grayı) \\
\hline
\end{tabular}

A study carried out by Beumer et al. (1996) demonstrated that L. monocytogenes and L. innocua are the usual Listeria spp. found in domestic environments. According to Beumer's (1996) study, Listeria spp. is frequently found in wet places and up to $37 \%$ was found in dishcloths. Taps are by their nature 
places were water is normally present and that can explain Listeria presence in our samples. Generally dishcloths are used to clean other surfaces in the kitchen and in the course of cleaning cross contamination can occur which may explain Listeria presence on the kitchen counter. Other workers have recognized the potential for spread of microbial contamination via cleaning utensils and the potential for some microorganisms to persist in the environment (Davis et al., 1968; Westwood and Mitchell, 1971).

Humans are exposed to this pathogen on a regular basis, because of its ubiquity in food products and the wider environment (Farber and Losos, 1988; Farber and Peterkin, 1991), therefore it is likely that domestic animals' paws will also be contaminated with this kind of pathogen.

L. monocytogenes has also been shown to adhere to various surface materials normally in contact with foods, such as stainless steel, rubber, glass and polypropylene (Blackman and Frank, 1996; Mafu et al., 1990) which can explain the WC knob contamination.

\subsection{Escherichia coli count}

Beumer and Kusumaningrum (2003) stated that places or objects with high numbers of microorganisms, which can simply be transmitted to other surfaces, are considered as reservoirs/disseminators and that even though raw material is most likely the major cause of contamination in the kitchen, the adjacent areas could also act as sources of free-living bacterial populations.

In a study carried out by Gorman et al. (2002), E. coli was isolated from chicken samples which crosscontaminated one or more surfaces in the domestic kitchen, namely dishcloths, person's hands, refrigerator handles, oven door handles and counter-tops. This was not surprising since $E$. coli is a normal inhabitant of the chicken intestine and contamination may occur during evisceration. E. coli are frequently isolated from human or animal faeces or from food products, like poultry (Saénz et al., 2001).

In this study several surfaces and utensils were contaminated with E. coli (Figure 3), resulting in collection of 13 samples, which is in agreement with several other studies where domestic kitchens were investigated for the presence of food pathogens (de Wit et al., 1979; de Boer and Hahné, 1990; Beumer and Giffel, 1999). High numbers of E. coli ( > 10 ${ }^{3} \mathrm{CFU} / \mathrm{swab}$ ) were detected on domestic animals, WC and kitchen taps, kitchen knob and counter, stove buttons, cutting board, refrigerator and dishwasher handle. Surprisingly the kitchen cloth, which is generally recognized as a potential source for spreading microorganisms, since bacteria tend to persist in these vehicles (Josephson et al., 1997; Rusin et al., 1998), presented low contamination level (<10² CFU/swab).

According to Adiga et al. (2012) among the different places in the kitchen, water taps were found to be most contaminated followed by stove knob, towel and refrigerator handle. The high incidence of pathogens on water taps and stove knobs/buttons, which are usually touched with unwashed hands 
during cleaning of raw food, was not a surprise since the moisture creates an ideal environment for bacterial growth.

Previous studies acknowledged that the kitchen generally shows more bacterial contamination than the bathroom (Finch et al., 1978; Scott et al., 1982; Speirs et al., 1995; Rusin et al., 1998) and there is evidence that the survival and transfer of potentially pathogenic bacteria via environmental surfaces is important (Sanborn, 1963; Humphrey et al., 1994). de Wit et al. (1979) showed that following the domestic preparation of chickens contaminated with E. coli, the bacteria were isolated from the cutting board, door handles and faucet handles where hand transfer must have occurred.

The presence of enteric bacteria such as E. coli, a widely accepted indicator of faecal contamination, might be introduced into the kitchen through raw foods, mainly of animal origin, people, pets and insects and may be a sign of a low level of hygiene among the kitchen users (Scott et al., 1982; William E. Oswald et al., 2007), i.e. poor hand washing.

\subsection{Enterobacteriaceae spp. count and detection}

Enterobacteriaceae isolates were collected and Figure 4 summarizes Enterobacteriaceae distribution in the domestic setting. As can be seen these kinds of microorganisms are distributed all around the house with high isolation rates (> $10^{2} \mathrm{CFU} / \mathrm{swab}$ ). Localities as domestic animal paws, kitchen tap, kitchen counter, stove buttons, refrigerator and dishwasher handle or kitchen cloth show levels of contamination higher than $10^{5} \mathrm{CFU} / \mathrm{swab}$.

In a study carried out by Scott et al. (1982), more than $80 \%$ of the 201 homes examined contained one or more species of enterobacteria and wet places like taps and dishcloths were highly contaminated. The normal contamination of dishcloths and other wet items with large numbers of organisms including enterobacteria, suggests that these objects may act not only as reservoirs but also as disseminators of contamination in the kitchen and although enteropathogenic organisms probably originate from the toilet and toilet usage, hands and cleaning cloths harbour and may disseminate these organisms.

Experimental studies with Salmonella spp. and E. coli show the likelihood for spread from toilets to bathroom surfaces and hands (Gerba et al., 1975; Barker and Bloomfield, 2000) and from hands to other surfaces (Rheinbaben et al., 2000).

In a study by Curtis et al. (2003), microbiological samples proved that faecal contamination of the domestic environment does occur, since faecal coliforms were found at a number of sites, not only in toilets and bathrooms but also in kitchens and on a variety of objects. The fact that a number of bathroom and toilet sites including door handles, were found to confirm signs of faecal contamination, suggests that hand-washing after using the toilet is not always regularly practised.

Several studies show that the intestinal tracts of animals generally harbour Enterobacteriaceae (Beutin, 1999; Guardabassi et al., 2004; Cobeljic et al., 2005; Jimenez et al., 2011); therefore it is normal that domestic animals may introduce these types of pathogens into the domestic setting. 
Adiga et al. (2012) studies demonstrated that bacterial contamination in the kitchen is common and among 10 kitchens analysed several sites, like refrigerator handle, kitchen stove and water taps, were infected with faecal microorganisms.

Enterobacteriaceae presence in all 11 places of the house, analysed in this study, is in accordance with several studies which showed that various species of bacteria can live on kitchen surfaces and cross-contamination can easily occur contaminating the food preparation counter, cloths, utensils and hands (de Wit et al., 1979; Ak et al., 1994; Scott, 1996; Gorman et al., 2002; Beumer and Kusumaningrum, 2003). 


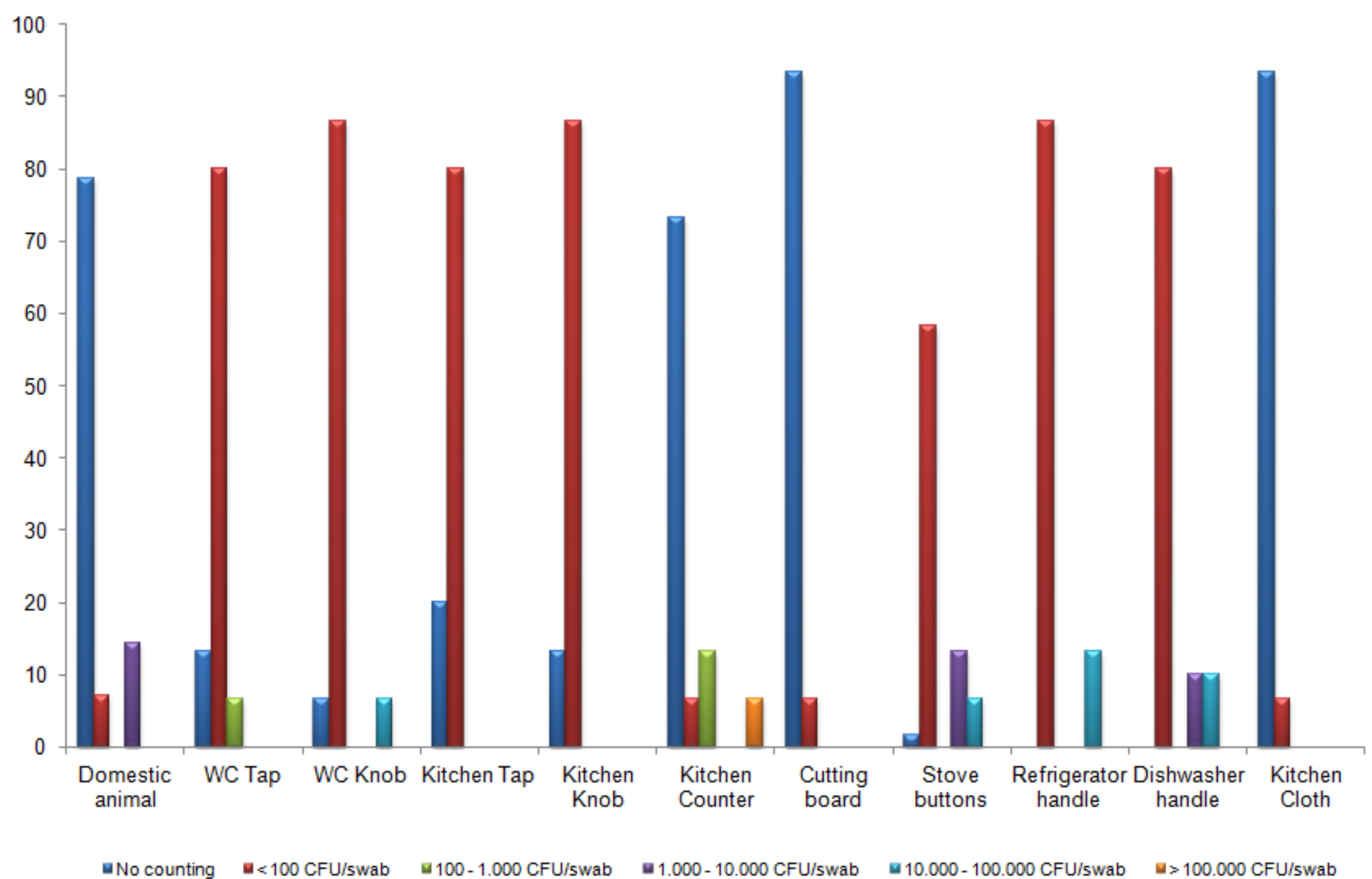

Figure 1 - Coagulase-positive Staphylococcus count (\%) by locality in domestic environments. 


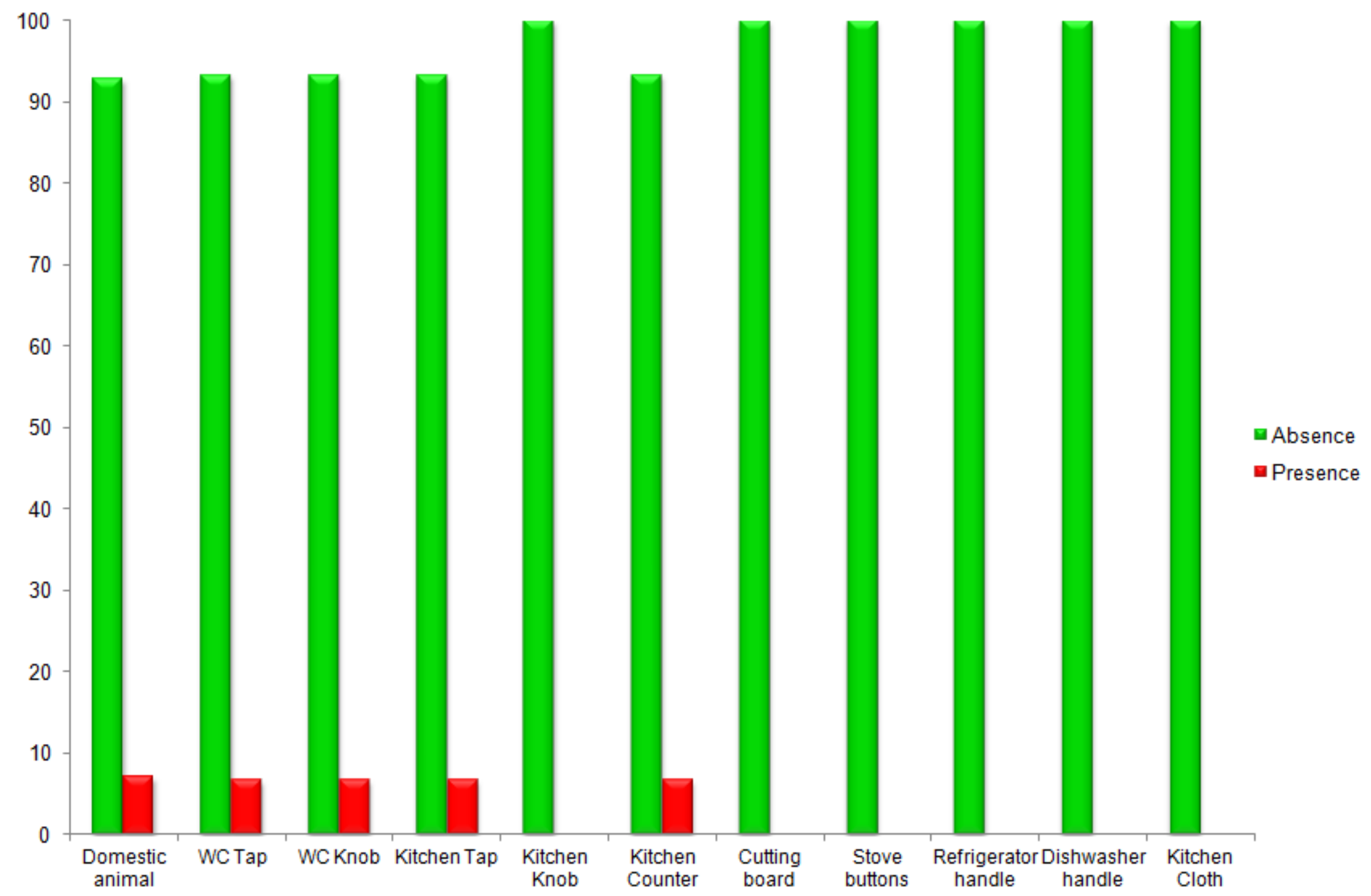

Figure 2 - Listeria spp. detection (\%) by locality in the domestic environment. 


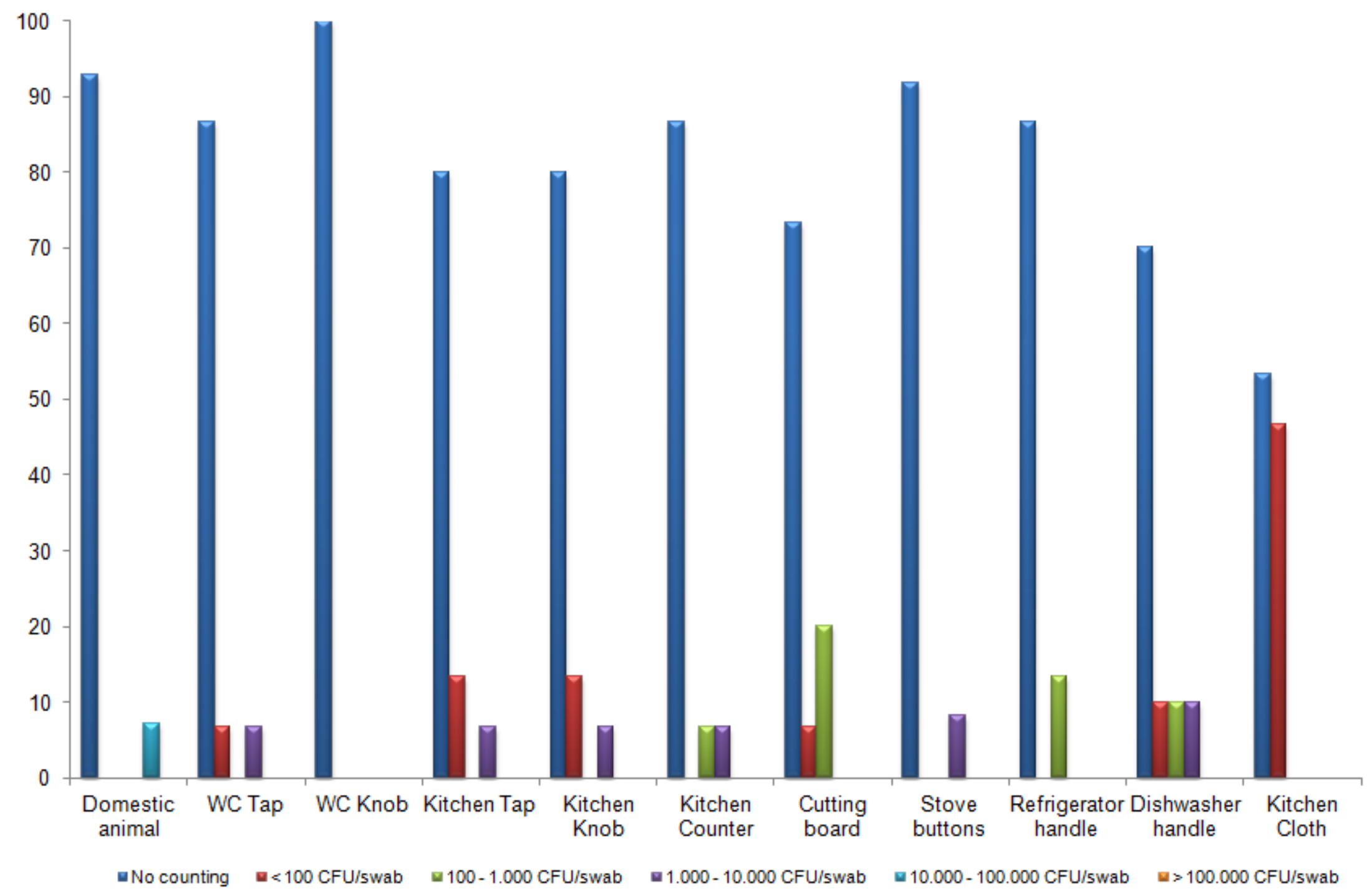

Figure 3 - Escherichia colicounts (\%) by locality in the domestic environment. 


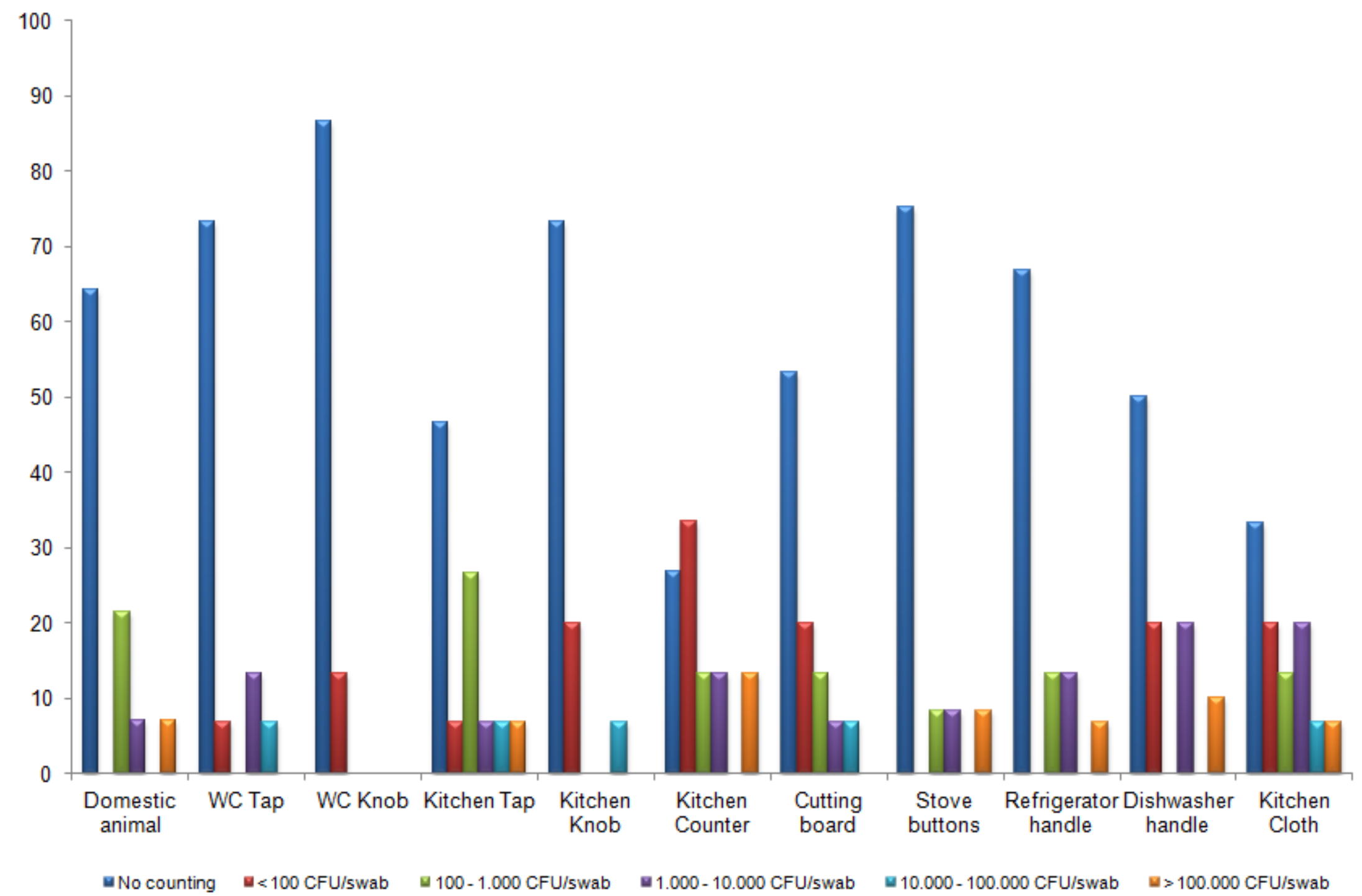

Figure 4 - Enterobacteriaceae counts (\%) by locality in the domestic environment. 


\subsection{Enterobacteriaceae antibiotic resistance}

For antibiotic resistance, all 351 isolates suspected to be Enterobacteriaceae were Gram-stained and tested for oxidase, catalase activity and fermentation of glucose. A total of 125 isolates glucosefermenting, Gram-negative, oxidase-negative, catalase-positive were considered to belong to the family Enterobacteriaceae, and only these were included in further testing. After primary identification, E. coli and Salmonella spp. were differentiated from all the other Enterobacteriaceae as shown in Table 2.

Table 2 - Escherichia coli and Salmonella spp. differentiation by biochemical tests

Biochemical Tests

\begin{tabular}{ccccccc}
\cline { 2 - 6 } Microorganism & \multirow{2}{*}{ Indole } & \multicolumn{5}{c}{ Triple Sugar Iron Agar (TSI) } \\
\cline { 2 - 7 } & & Glucose & Lactose & Sucrose & $\mathrm{H}_{2} \mathrm{~S}$ & Gas \\
\hline Escherichia coli & + & + & + & + & - & + \\
\hline Salmonella spp. & - & + & - & - & + & + \\
\hline
\end{tabular}

From this differentiation all 125 samples were separated in 3 major groups, for antibiotic resistance tests, namely 46 of E. coli, 19 of Salmonella spp. and all the remaining 60 isolates of other Enterobacteriaceae (Table 3 - see pag. 25).

High frequencies of antimicrobial resistance have been previously found in Enterobacteriaceae, in faecal flora as well as in clinical isolates (Kelch and Lee, 1978; Levy et al., 1988; Lester et al., 1990; Bonten et al., 1992; Leistevuo et al., 1996). Yet little or nothing is reported about antibiotic resistance in Enterobacteriaceae isolates found in the domestic setting, but there is plenty of evidence for enteric organisms found in this study with their origins in animals, humans and/or food.

Both animals and humans can introduce enteric pathogens into the dosmestic environment by crosscontamination when hands are poorly washed and paws have a direct contact to domestic surfaces. Food related problems arise when antimicrobials are used to treat infections and resistance is developed. In animals as in humans misuse of antibiotics may not only cause an increase of resistance in pathogenic bateria, but also in the endogenous flora of these animals. Resistant bacteria from these animals may be transferred to the human population, not only by direct contact, but also through food products of animal origin. These resistant bacteria may then either colonise humans and/or transfer their resistance genes to other bacteria in the human intestinal flora (van den Bogaard and Stobberingh, 2000).

At this time, it is well acknowledged that several antimicrobial resistant bacteria isolated from humans originated mainly from animals raised for human consumption (Aarestrups, 2000) and that such resistant bacteria may contaminate the meat derived from those animals (Sáenz et al., 2001). As a result, development of antimicrobial resistance amongst bacterial isolates from animal supplies can represent potential hazards to consumers through foodborne infections caused by these bacteria. In the past years, several studies have reported the antimicrobial resistance of some Enterobacteriaceae genera isolated from poultry, such as E. coli and Salmonella spp. (Antunes et al., 2003; Cormican et 
al., 2001; Guerra et al., 2003; Kijima-Tanaka et al., 2003; Sáenz et al., 2001; van den Bogaard et al., 2001).

Enterobacteriaceae family, a group containing some highly pathogenic Gram negative organisms, is universally used as an indicator of faecal contamination during food microbiology analyses and it includes zoonotic bacteria like Salmonella and E. coli. These microorganisms may cause severe infections and are becoming gradually more resistant to the generally used treatment antibiotics like tetracyclines, aminoglycosides, trimethoprim, fluoroquinolones and chloramphenicol (Paterson 2006), demonstrating multiple resistance and declining activity of several antibiotic groups such as the fluoroquinolones (Rhomberg et al., 2006).

According to Table 3, in this study Enterobacteriaceae strains were found to be resistant to ampicillin (28.3\%), trimethoprim (1.7\%) and nitrofurantoin (5.0\%). However, all strains were also sensitive to ciprofloxacin, gentamicin and nalidixic acid although resistance to Chloramphenicol and Tetracycline was practically non-existent (95 and $98.3 \%$ of sensitive strains, respectively).

Resistance of E. coli was found to ampicillin (41.3\%), chloramphenicol (4.3\%), tetracycline (6.5\%), nalidixic acid (6.5\%) and nitrofurantoin (4.3\%). Nevertheless all strains showed sensitivity to ciprofloxacin, gentamicin and trimethoprim.

Among Salmonella spp. isolates, $26.3 \%$ were resistant to ampicillin, $5.3 \%$ to chloramphenicol, $10.5 \%$ to tetracycline, $5.3 \%$ to nalidixic acid and $15.8 \%$ to nitrofurantoin. Ciprofloxacin, gentamicin and trimethoprim were shown to be very effective with $100 \%$ of sensitivity detected.

For all eight antimicrobials tested, overall no resistance was found to ciprofloxacin and gentamicin and for all 3 major groups resistance to ampicillin was common with a top score distinguished for $E$. coli with $41.3 \%$ of strains resistant, followed by Enterobacteriaceae with $28.3 \%$ and Salmonella spp. with $26.3 \%$. For nitrofurantoin $15.8 \%$ of Salmonella spp. strains were resistant, followed by Enterobacteriaceae spp. with $5.0 \%$ and E. coli with $4.3 \%$. This is in accordance with a study carried out by Osterblad et al. (1999) where antimicrobial sensitivity was shown in Enterobacteriaceae isolated from vegetables.

For example, urinary tract infections is a common illness that afects both community and hospital patients and is often caused by E. coli which is naturally susceptible to ampicillin even though about 50 - $60 \%$ of isolates are now resistant worlwide (Wu et al., 1992; Chomarat, 2000; Sefton, 2000; Gupta, 2001).

For more than 50 years nitrofurantoin has been an option for the management of urinary tract infection but its use declined with the introduction of alternative antimicrobials, like trimethoprim, although there has been a slow reappearance in its use because of continued low rates of resistance among common urologic pathogens (Hooton and Stamm, 1997). Nowadays, the only indication for nitrofurantoin is the management of bladder infection resulting from susceptible strains of $E$. coli, once it appears to be associated with lower cure rates (approximately 85\%) than other first line agents (90\% to 95\%), like trimethoprim (Warren et al., 1999). In the present study, isolates showed low levels of resistance to nitrofurantoin (15.8\%, 5.0\% and 4.3\% for Salmonella spp., Enterobacteriaceae and E. coli samples, 
respectively). A study conducted by Rampling et al., (1990) stated that Salmonella Enteritidis, isolated from poultry and from human enteric infection in the United Kingdom, showed high resistance rates which can be explained by the use of nitrofurans in the poultry industry.

Trimethoprim has been the core of therapy for urinary tract infection for the past many years with a $90 \%$ success rate as first-line agent indicated for the supervision of acute urinary tract infection and pyelonephritis (Hooton et al., 1995). It is very effective against most Enterobacteriaceae like E. coli, Klebsiella species, Enterobacter species, Morganella morganii, Proteus mirabilis and Proteus vulgaris although there has been a significant increase in the prevalence of resistance of $E$ coli.

Enterobacteriaceae family has shown worldwide trimethoprim resistance in chicken, pork, fish and even water (Tao et al., 2010; Su et al., 2011; Schwaiger et al., 2012). Generally E. coli and Salmonella spp. present higher resistance rates although this is not what was found in this study. Domestic environment Enterobacteriaceae showed a very low rate of resistance (1.7\%) while E. coli and Salmonella spp. strains were all sensitive to this kind of antimicrobial.

In some countries Salmonella and E. coli antibiotic resistance rates are reported to be high (Oppegaard et al., 2001; Ronald, 2002; Threlfall, 2002). In a study with 752 E. coli isolates from human and animal agriculture sources in several countries, tetracycline high frequency resistance rates were found in isolates from human and turkey samples (56\% and $71 \%$, respectively). The resistance profiles for cattle, chicken, and swine were similar with approximately $47 \%$ of cattle isolates resistant to tetracycline (Schroeder et al., 2002). This can be explained by the fact that tetracycline is the drug most often used in animal husbandry and is only a drug of second choice in human medicine (Mayrhofer et al., 2004). In another study performed by Schroeder et al. (2003) samples taken from retail beef, chicken, pork, and turkey resulted in $472 \mathrm{E}$. coli isolates, $59 \%$ of which were resistant to tetracycline, nalidixic acid (8\%), and chloramphenicol (6\%).

In contrast with these results, domestic isolates showed comparatively low rates of resistance to tetracycline with $6.5 \%$ and $10.5 \%$ for E. coli and Salmonella spp., respectively. All other Enterobacteriaceae were sensitive to this antimicrobial (98.3\%). Although resistance rates related to nalidixic acid (6.5\% for E. coli and 5.3\% for Salmonella spp.) and chloramphenicol (4.3\% for E. coli and $5.3 \%$ for Salmonella spp.) were much lower, this is in conformity with Schroeder et al. (2003) study.

In our study no resistance was determined for gentamicin or ciprofloxacin. This is in agreement with several studies but antimicrobial resistance can be modified depending on the nature of the food production system considered (Osterblad et al., 1999; van den Bogaard et al., 2000; Bywater et al., 2004; Fluckey et al., 2007; Miranda et al., 2008; Knezeviz and Petrovic, 2008).

In an antimicrobial susceptibility study of Enterobacteriaceae isolated from vegetables, no resistance was found to nalidixic acid but tetracycline and chloramphenicol showed low resistance rates (5.5 and $12 \%$, respectively) (Osterblad et al., 1999). This is consistent with some other antibiotic resistance studies where Enterobacteriaceae were isolated from milk, cheese and other dairy products. Isolates from milk products presented no resistance to nalidixic acid but some resistance was detected for tetracycline (14.28\%) and chloramphenicol (9.52\%). Among samples of cheese, $24 \%$ of isolates were 
resistant to tetracycline but no resistance was found to chloramphenicol and nalidixic acid. Dairy products showed high rates of resistance to tetracycline $(52.38 \%)$, but also no resistance was found to chloramphenicol and nalidixic acid (Hleba et al., 2011).

In our study nalidixic acid, chloramphenicol and tetracycline were shown to be effective against Enterobacteriaceae since no resistance was found.

Several studies reported Salmonella and E. coli food-related isolates showed resistance to trimethoprim and some declare that this resistance profile is due to treatments used in animal medicine (van den Bogaard et al., 2000; Cormican et al., 2001; Sáenz et al., 2001; van den Bogaard et al., 2001; Kijima-Tanaka et al., 2003; Bywater et al., 2004; Fluckey et al., 2007). Although some studies also stated food-related isolates showed sensitivity to trimethoprim (Lundin et al., 2008; Erdington et al., 2009) which is in accordance with this study where all Salmonella and E. coli strains were sensitive to this antibiotic.

Another interesting way of analysing our results was to organize antibiotic resistance rates by house (Table 4 to 6 - see pag. 26 to 28) and surface (Table 7 to 9 - see pag. 29 to 31 ).

From data in Table 4 it can be concluded that although other Enterobacteriaceae are not present in one house they are widely spread in all the others. Several antibiotic resistant strains were detected, mainly to ampicillin (House 1, 6, 9, 10, 11, 12 and 15) and ranging from $25.0 \%$ of isolates in House 9 to $66.7 \%$ in House 12, and nitrofurantoin (House 3, 4, 8, 12 and 15), ranging from 16.7\% in House 12 to $50.0 \%$ in House 3. Only one strain showed trimethoprim resistance in House 1 (9.1\%). All isolates were sensitive to ciprofloxacin, gentamicin and nalidixic acid although chloramphenicol and tetracycline present some intermediary isolates.

In conclusion, resistance to more than one antibiotic is verified in Enterobacteriaceae isolates from House 1 (ampicillin and trimethoprim), House 12 and House 15 (ampicillin and nitrofurantoin, in both cases). However, isolates from House 5 and House 13 showed no resistance to all 8 antibiotics tested. In Table 5 it can be seen that not all houses are contaminated with $E$. coli which is good news since some strains of these bacteria are considered a severe faecal pathogen. Once more strains showed resistance to ampicillin (House 3, 7, 9, 10, 13, 14 and 15) and nitrofurantoin (House 4 and 15) with rates ranging from $20.0 \%$ in House 10 to $100 \%$ in House 3 and $8.3 \%$ in House 15 to $50.0 \%$ in House 4 , respectively. Moreover in House $13,50.0 \%$ strains were found to be resistant to chloramphenicol, $75.0 \%$ to nalidixic acid and another $50.0 \%$ to tetracycline. Isolates from House 15 also showed some extra resistance to tetracycline although in low proportion ( 1 in 11 isolates). All E. coli domestic isolates showed no resistance to ciprofloxacin, gentamicin and trimethoprim.

In E. coli isolates resistance to more than one antibiotic was confirmed in House 13 (ampicillin, chloramphenicol, nalidixic acid and tetracycline) and House 15 (ampicillin, tetracycline and nitrofurantoin). Nevertheless, strains from House 5, House 8 and House 11 showed no resistance against all 8 antibiotic tested.

Table 6 presents Salmonella spp. resistance rates by house and it can can be seen that contamination is lower than for other bacteria presented above, since only 6 in 15 houses show contamination. In this 
case isolates exhibit high resistance rates against ampicillin in House 2, 3, 4 and 11 (varying from $25.0 \%$ in House 3 to $100 \%$ in House 4) while strains were resistant to nitrofurantoin in House 1 (50.0\%) and House 3 (25.0\%). Some strains were resistant to chloramphenicol (12.5\% in House 3), nalidixic acid $(50.0 \%$ in House 11$)$ and tetracycline $(25.0 \%$ in House 3$)$. Ciprofloxacin, gentamicin and trimethoprim are once more the most effective antibiotics with $100 \%$ sensitive strains.

In this case, Salmonella spp. isolates from two houses proved to be resistant to more than one antibiotic namely House 3 (ampicillin, chloramphenicol, tetracycline and nitrofurantoin) and House 11 (ampicillin and nalidixic acid). On the other hand, only House 7 showed no resistance for all 8 antibiotic tested.

Related to Table 7 it can be seen that Enterobacteriaceae show no resistance to chloramphenicol, ciprofloxacin, gentamicin, nalidixic acid and tetracycline even though some strains show intermediary breakpoints for chloramphenicol (domestic animal and kitchen counter) and tetracycline (kitchen tap). Resistance rates were detected against ampicillin (ranging from $9.1 \%$ in kitchen cloth to $100 \%$ in WC tap) and nitrofurantoin (ranging from $18.2 \%$ in kitchen cloth to $50 \%$ in dishwasher handle).

In summary, only those Enterobacteriaceae isolates found in the kitchen cloth showed resistance to more than one antibiotic (ampicillin and nitrofurantoin) while the refrigerator handle isolates presented no resistance to all 8 antibiotics tested.

From the data in Table 8, no E. coli was detected in WC knob but in all 9 other surfaces it is widely distributed. High resistance to ampicillin was found 9 localities, not including domestic animals' feet. The kitchen cloth and dishwasher handle isolates presented resistance to chloramphenicol, nalidixic acid and tetracycline while nitrofurantoin resistance was found in the strains from the kitchen counter and dishwasher handle. No resistance was found to ciprofloxacin, gentamicin and trimethoprim.

In conclusion, E. coli isolates found in the kitchen cloth and dishwasher handle showed resistance to more than one antibiotic. Resistance to ampicillin (75.0\%) and nitrofurantoin (50.0\%) was detected in kitchen counter isolates, while those from the kitchen cloth demonstrated resistance to ampicillin (54.5\%), chloramphenicol (9.1\%), nalidixic acid (18.2\%) and tetracycline (9.1\%). The dishwasher handle isolates showed low resistance (16.7\%) to 5 antibiotics namely ampicillin, chloramphenicol, nalidixic acid, tetracycline and nitrofurantoin. Only strains from domestic animals presented no resistance to all 8 antibiotics tested.

Analysing Table 9 Salmonella spp. shows no isolates from the WC tap, kitchen knob and stove buttons. Resistance was detected for 5 of the 8 antibiotics detected with ampicillin taking the lead with high rates in isolates from kitchen tap (50.0\%), cutting board (100\%) and kitchen cloth (50.0\%). Cutting board also showed evidence for resistance to chloramphenicol (50.0\%), tetracycline (100\%) and nitrofurantoin (100\%) and only one strain (33.3) showed resistance to nalidixic acid (from the kitchen counter). No isolates were resistant to ciprofloxacin, gentamicin or trimethoprim.

Therefore, of the Salmonella spp. isolates, only those from the cutting board presented resistance to more than one antibiotic namely, ampicillin, chloramphenicol, tetracycline and nitrofurantoin. In contrast, the isolates from the WC knob, refrigerator and dishwasher handles revealed no resistance. 
Overall, multi-resistance, to more than one antibiotic, was found in this study. Analysing Annex 1, where all the different antibiotic profiles are shown, in all 15 Houses, we can assume that diverse sources of enteric bacteria were found probably from different origins as animals, humans and/or foodstuff. 
Table 3 - In vitro susceptibility of Enterobacteriaceae isolates to several antibiotics and minimum inhibitory concentration (MIC) breakpoints

\begin{tabular}{|c|c|c|c|c|c|c|c|c|c|c|c|c|c|}
\hline \multirow[b]{2}{*}{ Class } & \multirow[b]{2}{*}{ Antibiotic } & \multicolumn{3}{|c|}{ MIC $(\mu \mathrm{g} / \mathrm{mL})$ Breakpoints } & \multicolumn{3}{|c|}{ Other Enterobacteriaceae isolates } & \multicolumn{3}{|c|}{ Escherichia coli isolates } & \multicolumn{3}{|c|}{ Salmonella spp. isolates } \\
\hline & & $\begin{array}{c}\text { Sensitive } \\
\text { (S) }\end{array}$ & $\begin{array}{l}\text { Intermediary } \\
\text { (I) }\end{array}$ & $\begin{array}{l}\text { Resistant } \\
\text { (R) }\end{array}$ & $\begin{array}{c}\text { Number of } \\
\text { sensitive } \\
\text { isolates (\%) }\end{array}$ & $\begin{array}{l}\text { Number of } \\
\text { intermediary } \\
\text { isolates (\%) }\end{array}$ & $\begin{array}{c}\text { Number of } \\
\text { resistant } \\
\text { isolates (\%) }\end{array}$ & $\begin{array}{c}\text { Number of } \\
\text { sensitive } \\
\text { isolates (\%) }\end{array}$ & $\begin{array}{c}\text { Number of } \\
\text { intermediary } \\
\text { isolates (\%) }\end{array}$ & $\begin{array}{l}\text { Number of } \\
\text { resistant } \\
\text { isolates (\%) }\end{array}$ & $\begin{array}{c}\text { Number of } \\
\text { sensitive } \\
\text { isolates (\%) }\end{array}$ & $\begin{array}{c}\text { Number of } \\
\text { intermediary } \\
\text { isolates (\%) }\end{array}$ & $\begin{array}{l}\text { Number of } \\
\text { resistant } \\
\text { isolates (\%) }\end{array}$ \\
\hline Penicillins & Ampicillin & $\leq 8$ & 16 & $\geq 32$ & $37(61.7)$ & $6(10.0)$ & $17(28.3)$ & $21(45.6)$ & $6(13.0)$ & $19(41.3)$ & $10(52.6)$ & $4(21.1)$ & $5(26.3)$ \\
\hline Phenicols & Chloramphenicol & $\leq 8$ & 16 & $\geq 32$ & $57(95.0)$ & $3(5.0)$ & & $44(95.7)$ & & $2(4.3)$ & $16(84.2)$ & $2(10.5)$ & $1(5.3)$ \\
\hline Fluoroquinolones & Ciprofloxacin & $\leq 1$ & 2 & $\geq 4$ & $60(100)$ & & & $46(100)$ & & & $19(100)$ & & \\
\hline Aminoglycosides & Gentamicin & $\leq 4$ & 8 & $\geq 16$ & $60(100)$ & & & $46(100)$ & & & $19(100)$ & & \\
\hline Tetracyclines & Tetracycline & $\leq 4$ & 8 & $\geq 16$ & $59(98.3)$ & $1(1.7)$ & & $42(91.3)$ & $1(2.2)$ & $3(6.5)$ & $13(68.4)$ & $4(21.1)$ & $2(10.5)$ \\
\hline Quinolones & Nalidixic Acid & $\leq 16$ & --- & $\geq 32$ & $60(100)$ & & & $43(93.5)$ & & $3(6.5)$ & $18(94.7)$ & & $1(5.3)$ \\
\hline $\begin{array}{l}\text { Folate pathway } \\
\text { inhibitor }\end{array}$ & Trimethoprim & $\leq 8$ & --- & $\geq 16$ & $59(98.3)$ & & $1(1.7)$ & $46(100)$ & & & $19(100)$ & & \\
\hline Nitrofurantoins & Nitrofurantoin & $\leq 32$ & 64 & $\geq 128$ & $34(56.7)$ & 23 (38.3) & $3(5.0)$ & 39 (84.8) & $5(10.9)$ & $2(4.3)$ & $13(68.4)$ & $3(15.8)$ & $3(15.8)$ \\
\hline
\end{tabular}

Blank spaces indicate that no MIC value was determined for that concentration. 
Table 4 - In vitro susceptibility of other Enterobacteriaceae isolates to several antibiotics and minimum inhibitory concentration (MIC) breakpoints by house

Number (\%) other Enterobacteriaceae isolates

\begin{tabular}{|c|c|c|c|c|c|c|c|c|c|c|c|c|c|c|c|}
\hline \multirow[b]{2}{*}{ Antibiotic } & \multirow[b]{2}{*}{$\begin{array}{l}\text { MIC }(\mu \mathrm{g} / \mathrm{mL}) \\
\text { Breakpoints }\end{array}$} & \multicolumn{14}{|c|}{ 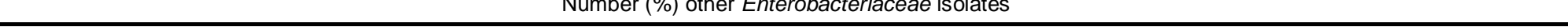 } \\
\hline & & House 1 & House 3 & House 4 & House 5 & House 6 & House 7 & House 8 & House 9 & House 10 & House 11 & House 12 & House 13 & House 14 & House 15 \\
\hline \multirow{3}{*}{ Ampicillin } & Sensitive & $6(54.5)$ & $2(100)$ & $1(33.3)$ & $3(100)$ & $1(25.0)$ & $3(100)$ & $4(100)$ & $3(75.0)$ & $6(60.0)$ & $2(66.7)$ & $2(33.3)$ & $1(100)$ & $1(50.0)$ & $3(50.0)$ \\
\hline & Intermediary & $1(9.1)$ & & $2(66.7)$ & & $1(25.0)$ & & & & & & & & $1(50.0)$ & $1(16.7)$ \\
\hline & Resistant & $4(36.4)$ & & & & $2(50.0)$ & & & $1(25.0)$ & $4(40.0)$ & $1(33.3)$ & $4(66.7)$ & & & 2 (33.3) \\
\hline \multirow{3}{*}{ Chloramphenicol } & Sensitive & $11(100)$ & $2(100)$ & $3(100)$ & $3(100)$ & $3(75.0)$ & $3(100)$ & $4(100)$ & $4(100)$ & $10(100)$ & $3(100)$ & $4(66.7)$ & $1(100)$ & $2(100)$ & $6(100)$ \\
\hline & Intermediary & & & & & $1(25.0)$ & & & & & & 2 (33.3) & & & \\
\hline & Resistant & & & & & & & & & & & & & & \\
\hline \multirow{3}{*}{ Ciprofloxacin } & Sensitive & $11(100)$ & $2(100)$ & $3(100)$ & $3(100)$ & $4(100)$ & $3(100)$ & $4(100)$ & $4(100)$ & $10(100)$ & $3(100)$ & $6(100)$ & $1(100)$ & $2(100)$ & $6(100)$ \\
\hline & Intermediary & & & & & & & & & & & & & & \\
\hline & Resistant & & & & & & & & & & & & & & \\
\hline \multirow{3}{*}{ Gentamicin } & Sensitive & $11(100)$ & $2(100)$ & $3(100)$ & $3(100)$ & $4(100)$ & $3(100)$ & $4(100)$ & $4(100)$ & $10(100)$ & $3(100)$ & $6(100)$ & $1(100)$ & $2(100)$ & $6(100)$ \\
\hline & Intermediary & & & & & & & & & & & & & & \\
\hline & Resistant & & & & & & & & & & & & & & \\
\hline \multirow{3}{*}{ Nalidixic Acid } & Sensitive & $11(100)$ & $2(100)$ & $3(100)$ & $3(100)$ & $4(100)$ & $3(100)$ & $4(100)$ & $4(100)$ & $10(100)$ & $3(100)$ & $6(100)$ & $1(100)$ & $2(100)$ & $6(100)$ \\
\hline & Intermediary & & & & & & & & & & & & & & \\
\hline & Resistant & & & & & & & & & & & & & & \\
\hline \multirow{3}{*}{ Tetracycline } & Sensitive & $11(100)$ & $1(50.0)$ & $2(66.7)$ & $3(100)$ & $4(100)$ & $3(100)$ & $4(100)$ & $4(100)$ & $8(80.0)$ & $3(100)$ & $6(100)$ & $1(100)$ & $2(100)$ & $6(100)$ \\
\hline & Intermediary & & $1(50.0)$ & $1(33.3)$ & & & & & & $2(20.0)$ & & & & & \\
\hline & Resistant & & & & & & & & & & & & & & \\
\hline \multirow{3}{*}{ Trimethoprim } & Sensitive & $10(90.9)$ & $2(100)$ & $3(100)$ & $3(100)$ & $4(100)$ & $3(100)$ & $4(100)$ & $4(100)$ & $10(100)$ & $3(100)$ & $6(100)$ & $1(100)$ & $2(100)$ & $6(100)$ \\
\hline & Intermediary & & & & & & & & & & & & & & \\
\hline & Resistant & $1(9.1)$ & & & & & & & & & & & & & \\
\hline \multirow{3}{*}{ Nitrofurantoin } & Sensitive & $5(45.5)$ & $1(50.0)$ & $1(33.3)$ & $1(33.3)$ & $2(50.0)$ & $1(33.3)$ & $2(50.0)$ & $1(25.0)$ & $10(100)$ & $1(33.3)$ & $2(33.3)$ & $1(100)$ & $2(100)$ & 5 (83.3) \\
\hline & Intermediary & $6(54.5)$ & & $1(33.3)$ & $2(66.7)$ & $2(50.0)$ & $2(66.7)$ & $1(25.0)$ & $3(75.0)$ & & $2(66.7)$ & $3(50.0)$ & & & \\
\hline & Resistant & & $1(50.0)$ & $1(33.3)$ & & & & $1(25.0)$ & & & & $1(16.7)$ & & & $1(16.7)$ \\
\hline
\end{tabular}

Blank spaces indicate that no MIC value was determined for that concentration.

Note: No other Enterobacteriaceae isolates were detected in House 2 therefore no results were here included. 
Table 5 - In vitro susceptibility of Escherichia coli isolates to several antibiotics and minimum inhibitory concentration (MIC) breakpoints by house

Number (\%) Escherichia coli isolates

\begin{tabular}{|c|c|c|c|c|c|c|c|c|c|c|c|c|}
\hline \multirow[b]{2}{*}{ Antibiotic } & \multirow[b]{2}{*}{$\begin{array}{l}\text { MIC }(\mu \mathrm{g} / \mathrm{mL}) \\
\text { Breakpoints }\end{array}$} & \\
\hline & & House 3 & House 4 & House 5 & House 7 & House 8 & House 9 & House 10 & House 11 & House 13 & House 14 & House 15 \\
\hline \multirow{3}{*}{ Ampicillin } & Sensitive & & $1(50.0)$ & $3(75.0)$ & & $4(100)$ & & $3(60.0)$ & & $2(50.0)$ & & $9(75.0)$ \\
\hline & Intermediary & & $1(50.0)$ & $1(25.0)$ & $1(33.3)$ & & & $1(20.0)$ & $3(100)$ & & & \\
\hline & Resistant & $2(100)$ & & & $2(66.7)$ & & $2(100)$ & $1(20.0)$ & & $2(50.0)$ & $3(100)$ & $3(25.0)$ \\
\hline \multirow{3}{*}{ Chloramphenicol } & Sensitive & $2(100)$ & $2(100)$ & $4(100)$ & $3(100)$ & $4(100)$ & $2(100)$ & $5(100)$ & $3(100)$ & $2(50.0)$ & $3(100)$ & $12(100)$ \\
\hline & Intermediary & & & & & & & & & & & \\
\hline & Resistant & & & & & & & & & $2(50.0)$ & & \\
\hline \multirow{3}{*}{ Ciprofloxacin } & Sensitive & $2(100)$ & $2(100)$ & $4(100)$ & $3(100)$ & $4(100)$ & $2(100)$ & $5(100)$ & $3(100)$ & $4(100)$ & $3(100)$ & $12(100)$ \\
\hline & Intermediary & & & & & & & & & & & \\
\hline & Resistant & & & & & & & & & & & \\
\hline \multirow{3}{*}{ Gentamicin } & Sensitive & $2(100)$ & $2(100)$ & $4(100)$ & $3(100)$ & $4(100)$ & $2(100)$ & $5(100)$ & $3(100)$ & $4(100)$ & $3(100)$ & $12(100)$ \\
\hline & Intermediary & & & & & & & & & & & \\
\hline & Resistant & & & & & & & & & & & \\
\hline \multirow{3}{*}{ Nalidixic Acid } & Sensitive & $2(100)$ & $2(100)$ & $4(100)$ & $3(100)$ & $4(100)$ & $2(100)$ & $5(100)$ & $3(100)$ & $1(25.0)$ & $3(100)$ & $12(100)$ \\
\hline & Intermediary & & & & & & & & & & & \\
\hline & Resistant & & & & & & & & & $3(75.0)$ & & \\
\hline \multirow{3}{*}{ Tetracycline } & Sensitive & $2(100)$ & $1(50.0)$ & $4(100)$ & $3(100)$ & $4(100)$ & $2(100)$ & $5(100)$ & $3(100)$ & $2(50.0)$ & $3(100)$ & $11(91.7)$ \\
\hline & Intermediary & & $1(50.0)$ & & & & & & & & & \\
\hline & Resistant & & & & & & & & & $2(50.0)$ & & $1(8.3)$ \\
\hline \multirow{3}{*}{ Trimethoprim } & Sensitive & $2(100)$ & $2(100)$ & $4(100)$ & $3(100)$ & $4(100)$ & $2(100)$ & $5(100)$ & $3(100)$ & $4(100)$ & $3(100)$ & $12(100)$ \\
\hline & Intermediary & & & & & & & & & & & \\
\hline & Resistant & & & & & & & & & & & \\
\hline \multirow{3}{*}{ Nitrofurantoin } & Sensitive & $2(100)$ & & $3(75.0)$ & $3(100)$ & $3(75.0)$ & $2(100)$ & $5(100)$ & & $4(100)$ & $3(100)$ & $11(91.7)$ \\
\hline & Intermediary & & $1(50.0)$ & $1(25.0)$ & & $1(25.0)$ & & & $3(100)$ & & & \\
\hline & Resistant & & $1(50.0)$ & & & & & & & & & $1(8.3)$ \\
\hline
\end{tabular}


Table 6 - In vitro susceptibility of Salmonella spp. isolates to several antibiotics and minimum inhibitory concentration (MIC) breakpoints by house

Number (\%) Salmonella spp. isolates

\begin{tabular}{|c|c|c|c|c|c|c|c|}
\hline \multirow[b]{2}{*}{ Antibiotic } & \multirow[b]{2}{*}{$\begin{array}{l}\text { MIC }(\mu \mathrm{g} / \mathrm{mL}) \\
\text { Breakpoints }\end{array}$} & \\
\hline & & House 1 & House 2 & House 3 & House 4 & House 7 & House 11 \\
\hline \multirow{3}{*}{ Ampicillin } & Sensitive & $2(100)$ & $2(50.0)$ & $4(50.0)$ & & $1(50.0)$ & $1(50.0)$ \\
\hline & Intermediary & & $1(25.0)$ & $2(25.0)$ & & $1(50.0)$ & \\
\hline & Resistant & & $1(25.0)$ & $2(25.0)$ & $1(100)$ & & $1(50.0)$ \\
\hline \multirow{3}{*}{ Chloramphenicol } & Sensitive & $2(100)$ & $3(75.0)$ & $6(75.0)$ & $1(100)$ & $2(100)$ & $2(100)$ \\
\hline & Intermediary & & $1(25.0)$ & $1(12.5)$ & & & \\
\hline & Resistant & & & $1(12.5)$ & & & \\
\hline \multirow{3}{*}{ Ciprofloxacin } & Sensitive & $2(100)$ & $4(100)$ & $8(100)$ & $1(100)$ & $2(100)$ & $2(100)$ \\
\hline & Intermediary & & & & & & \\
\hline & Resistant & & & & & & \\
\hline \multirow{3}{*}{ Gentamicin } & Sensitive & $2(100)$ & $4(100)$ & $8(100)$ & $1(100)$ & $2(100)$ & $2(100)$ \\
\hline & Intermediary & & & & & & \\
\hline & Resistant & & & & & & \\
\hline \multirow{3}{*}{ Nalidixic Acid } & Sensitive & $2(100)$ & $4(100)$ & $8(100)$ & $1(100)$ & $2(100)$ & $1(50.0)$ \\
\hline & Intermediary & & & & & & \\
\hline & Resistant & & & & & & $1(50.0)$ \\
\hline \multirow{3}{*}{ Tetracycline } & Sensitive & & $3(75.0)$ & $6(75.0)$ & & $2(100)$ & $2(100)$ \\
\hline & Intermediary & $2(100)$ & $1(25.0)$ & & $1(100)$ & & \\
\hline & Resistant & & & $2(25.0)$ & & & \\
\hline \multirow{3}{*}{ Trimethoprim } & Sensitive & $2(100)$ & $4(100)$ & $8(100)$ & $1(100)$ & $2(100)$ & $2(100)$ \\
\hline & Intermediary & & & & & & \\
\hline & Resistant & & & & & & \\
\hline \multirow{3}{*}{ Nitrofurantoin } & Sensitive & & $4(100)$ & $6(75.0)$ & & $1(50.0)$ & $2(100)$ \\
\hline & Intermediary & $1(50.0)$ & & & $1(100)$ & $1(50.0)$ & \\
\hline & Resistant & $1(50.0)$ & & $2(25.0)$ & & & \\
\hline
\end{tabular}

Blank spaces indicate that no MIC value was determined for that concentration.

Note: No Salmonella spp. isolates were detected in House $5,6,8,9,10,12,13,14$ and 15 , therefore no results were here included. 
Table 7 - In vitro susceptibility of other Enterobacteriaceae isolates to several antibiotics and minimum inhibitory concentration (MIC) breakpoints, by surface

\begin{tabular}{|c|c|c|c|c|c|c|c|c|c|c|c|c|}
\hline \multirow[b]{2}{*}{ Antibiotic } & \multirow[b]{2}{*}{$\begin{array}{l}\text { MIC }(\mu \mathrm{g} / \mathrm{mL}) \\
\text { Breakpoints }\end{array}$} & \multicolumn{11}{|c|}{ Number (\%) Enterobacteriaceae isolates } \\
\hline & & $\begin{array}{c}\text { Domestic } \\
\text { Animal }\end{array}$ & WC Knob & WC Tap & $\begin{array}{l}\text { Kitchen } \\
\text { Knob }\end{array}$ & Kitchen Tap & $\begin{array}{c}\text { Stove } \\
\text { Buttons }\end{array}$ & $\begin{array}{l}\text { Kitchen } \\
\text { Counter }\end{array}$ & $\begin{array}{l}\text { Cutting } \\
\text { Board }\end{array}$ & $\begin{array}{l}\text { Kitchen } \\
\text { Cloth }\end{array}$ & $\begin{array}{c}\text { Refrigerator } \\
\text { Handle }\end{array}$ & $\begin{array}{c}\text { Dishwasher } \\
\text { Handle }\end{array}$ \\
\hline \multirow{3}{*}{ Ampicillin } & Sensitive & $5(62.5)$ & $4(100)$ & & $3(75.0)$ & $4(50.0)$ & $2(40.0)$ & $5(50.0)$ & $1(25.0)$ & $10(90.9)$ & $3(75.0)$ & $1(50.0)$ \\
\hline & Intermediary & $3(37.5)$ & & & & $2(25.0)$ & $1(20.0)$ & & & & $1(25.0)$ & $1(50.0)$ \\
\hline & Resistant & & & $2(100)$ & $1(25.0)$ & $2(25.0)$ & $2(40.0)$ & $5(50.0)$ & $3(75.0)$ & $1(9.1)$ & & \\
\hline \multirow[b]{2}{*}{ Chloramphenicol } & Sensitive & $7(87.5)$ & $4(100)$ & $2(100)$ & $4(100)$ & $8(100)$ & $6(100)$ & $8(80.0)$ & $4(100)$ & $11(100)$ & $4(100)$ & $2(100)$ \\
\hline & $\begin{array}{c}\text { Intermediary } \\
\text { Resistant }\end{array}$ & $1(12.5)$ & & & & & & $2(20.0)$ & & & & \\
\hline Ciprofloxacin & $\begin{array}{c}\text { Sensitive } \\
\text { Intermediary } \\
\text { Resistant }\end{array}$ & $8(100)$ & $4(100)$ & $2(100)$ & $4(100)$ & $8(100)$ & $6(100)$ & $10(100)$ & $4(100)$ & $11(100)$ & $4(100)$ & $2(100)$ \\
\hline Gentamicin & $\begin{array}{c}\text { Sensitive } \\
\text { Intermediary } \\
\text { Resistant }\end{array}$ & $8(100)$ & $4(100)$ & $2(100)$ & $4(100)$ & $8(100)$ & $6(100)$ & $10(100)$ & $4(100)$ & $11(100)$ & $4(100)$ & $2(100)$ \\
\hline Nalidixic Acid & $\begin{array}{c}\text { Sensitive } \\
\text { Intermediary } \\
\text { Resistant }\end{array}$ & $8(100)$ & $4(100)$ & $2(100)$ & $4(100)$ & $8(100)$ & $6(100)$ & $10(100)$ & $4(100)$ & $11(100)$ & $4(100)$ & $2(100)$ \\
\hline Tetracycline & $\begin{array}{c}\text { Sensitive } \\
\text { Intermediary } \\
\text { Resistant }\end{array}$ & $8(100)$ & $4(100)$ & $2(100)$ & $4(100)$ & $\begin{array}{l}7 \text { (87.5) } \\
1(12.5)\end{array}$ & $6(100)$ & $10(100)$ & $4(100)$ & $11(100)$ & $4(100)$ & $2(100)$ \\
\hline Trimethoprim & $\begin{array}{c}\text { Sensitive } \\
\text { Intermediary } \\
\text { Resistant }\end{array}$ & $\begin{array}{l}7(87.5) \\
1(12.5)\end{array}$ & $4(100)$ & $2(100)$ & $4(100)$ & $8(100)$ & $6(100)$ & $10(100)$ & $4(100)$ & $11(100)$ & $4(100)$ & $2(100)$ \\
\hline \multirow[t]{2}{*}{ Nitrofurantoin } & $\begin{array}{c}\text { Sensitive } \\
\text { Intermediary }\end{array}$ & $\begin{array}{l}3(37.5) \\
5(62.5)\end{array}$ & $3(75.0)$ & $2(100)$ & $4(100)$ & $\begin{array}{l}6(75.0) \\
2(25.0)\end{array}$ & $6(100)$ & $\begin{array}{l}5(50.0) \\
5(50.0)\end{array}$ & $\begin{array}{l}2(50.0) \\
2(50.0)\end{array}$ & $\begin{array}{l}4(36.4) \\
5(45.4)\end{array}$ & $4(100)$ & $1(50.0)$ \\
\hline & Resistant & & $1(25.0)$ & & & & & & & $2(18.2)$ & & $1(50.0)$ \\
\hline
\end{tabular}

Blank spaces indicate that no MIC value was determined for that concentration.

Table 8 - In vitro susceptibility of Escherichia coli isolates to several antibiotics and minimum inhibitory concentration (MIC) breakpoints, by surface 
Number (\%) Escherichia coli isolates

\begin{tabular}{|c|c|c|c|c|c|c|c|c|c|c|c|}
\hline \multirow[b]{2}{*}{ Antibiotic } & \multirow[b]{2}{*}{$\begin{array}{c}\mathrm{MIC}(\mu \mathrm{g} / \mathrm{mL}) \\
\text { Breakpoints }\end{array}$} & \\
\hline & & $\begin{array}{c}\text { Domestic } \\
\text { Animal }\end{array}$ & WC Tap & Kitchen Knob & Kitchen Tap & Stove Buttons & $\begin{array}{l}\text { Kitchen } \\
\text { Counter }\end{array}$ & Cutting Board & Kitchen Cloth & $\begin{array}{l}\text { Refrigerator } \\
\text { Handle }\end{array}$ & $\begin{array}{c}\text { Dishwasher } \\
\text { Handle }\end{array}$ \\
\hline \multirow{3}{*}{ Ampicillin } & Sensitive & $2(100)$ & $2(50.0)$ & $2(50.0)$ & $2(50.0)$ & & $1(25.0)$ & $2(33.3)$ & $3(27.3)$ & $1(50.0)$ & 5 (83.3) \\
\hline & Intermediary & & $1(25.0)$ & & $1(25.0)$ & & & $2(33.3)$ & $2(18.2)$ & & \\
\hline & Resistant & & $1(25.0)$ & $2(50.0)$ & $1(25.0)$ & $1(100)$ & $3(75.0)$ & $2(33.3)$ & $6(54.5)$ & $1(50.0)$ & $1(16.7)$ \\
\hline \multirow{3}{*}{ Chloramphenicol } & Sensitive & $2(100)$ & $4(100)$ & $4(100)$ & $4(100)$ & $1(100)$ & $4(100)$ & $6(100)$ & $10(90.9)$ & $2(100)$ & $5(83.3)$ \\
\hline & Intermediary & & & & & & & & & & \\
\hline & Resistant & & & & & & & & $1(9.1)$ & & $1(16.7)$ \\
\hline \multirow{3}{*}{ Ciprofloxacin } & Sensitive & $2(100)$ & $4(100)$ & $4(100)$ & $4(100)$ & $1(100)$ & $4(100)$ & $6(100)$ & $11(100)$ & $2(100)$ & $6(100)$ \\
\hline & Intermediary & & & & & & & & & & \\
\hline & Resistant & & & & & & & & & & \\
\hline \multirow{3}{*}{ Gentamicin } & Sensitive & $2(100)$ & $4(100)$ & $4(100)$ & $4(100)$ & $1(100)$ & $4(100)$ & $6(100)$ & $11(100)$ & $2(100)$ & $6(100)$ \\
\hline & Intermediary & & & & & & & & & & \\
\hline & Resistant & & & & & & & & & & \\
\hline \multirow{3}{*}{ Nalidixic Acid } & Sensitive & $2(100)$ & $4(100)$ & $4(100)$ & $4(100)$ & $1(100)$ & $4(100)$ & $6(100)$ & $9(81.8)$ & $2(100)$ & $5(83.3)$ \\
\hline & Intermediary & & & & & & & & & & \\
\hline & Resistant & & & & & & & & $2(18.2)$ & & $1(16.7)$ \\
\hline \multirow{3}{*}{ Tetracycline } & Sensitive & $2(100)$ & $4(100)$ & $4(100)$ & $4(100)$ & $1(100)$ & $4(100)$ & $6(100)$ & $10(90.9)$ & $2(100)$ & $5(83.3)$ \\
\hline & Intermediary & & & & & & & & & & \\
\hline & Resistant & & & & & & & & $1(9.1)$ & & $1(16.7)$ \\
\hline \multirow{3}{*}{ Trimethoprim } & Sensitive & $2(100)$ & $4(100)$ & $4(100)$ & $4(100)$ & $1(100)$ & $4(100)$ & $6(100)$ & $11(100)$ & $2(100)$ & $6(100)$ \\
\hline & Intermediary & & & & & & & & & & \\
\hline & Resistant & & & & & & & & & & \\
\hline \multirow{3}{*}{ Nitrofurantoin } & Sensitive & $2(100)$ & $4(100)$ & $4(100)$ & $4(100)$ & $1(100)$ & $1(25.0)$ & $4(66.7)$ & $9(81.8)$ & $2(100)$ & 5 (83.3) \\
\hline & Intermediary & & & & & & $1(25.0)$ & $2(33.3)$ & $2(18.2)$ & & \\
\hline & Resistant & & & & & & $2(50.0)$ & & & & $1(16.7)$ \\
\hline
\end{tabular}

Blank spaces indicate that no MIC value was determined for that concentration.

Note: No Escherichia coli isolates were detected in WC knob, therefore no results were here included.

Table 9 - In vitro susceptibility of Salmonella spp. isolates to several antibiotics and minimum inhibitory concentration (MIC) breakpoints, by surface 
Number (\%) Salmonella spp. isolates

\begin{tabular}{|c|c|c|c|c|c|c|c|c|c|}
\hline \multirow[b]{2}{*}{ Antibiotic } & \multirow[b]{2}{*}{$\begin{array}{c}\mathrm{MIC}(\mu \mathrm{g} / \mathrm{mL}) \\
\text { Breakpoints }\end{array}$} & \\
\hline & & Domestic Animal & WC Knob & Kitchen Tap & Kitchen Counter & Cutting Board & Kitchen Cloth & $\begin{array}{c}\text { Refrigerator } \\
\text { Handle }\end{array}$ & $\begin{array}{c}\text { Dishwasher } \\
\text { Handle }\end{array}$ \\
\hline \multirow{3}{*}{ Ampicillin } & Sensitive & $3(75.0)$ & $2(100)$ & $1(25.0)$ & 1 (33.3) & & $1(50.0)$ & & $1(100)$ \\
\hline & Intermediary & $1(25.0)$ & & $1(25.0)$ & $2(66.7)$ & & & $1(100)$ & \\
\hline & Resistant & & & $2(50.0)$ & & $2(100)$ & $1(50.0)$ & & \\
\hline \multirow{3}{*}{ Chloramphenicol } & Sensitive & $4(100)$ & $2(100)$ & $4(100)$ & $3(100)$ & & $1(50.0)$ & $1(100)$ & $1(100)$ \\
\hline & Intermediary & & & & & $1(50.0)$ & $1(50.0)$ & & \\
\hline & Resistant & & & & & $1(50.0)$ & & & \\
\hline \multirow{3}{*}{ Ciprofloxacin } & Sensitive & $4(100)$ & $2(100)$ & $4(100)$ & $3(100)$ & $2(100)$ & $2(100)$ & $1(100)$ & $1(100)$ \\
\hline & Intermediary & & & & & & & & \\
\hline & Resistant & & & & & & & & \\
\hline \multirow{3}{*}{ Gentamicin } & Sensitive & $4(100)$ & $2(100)$ & $4(100)$ & $3(100)$ & $2(100)$ & $2(100)$ & $1(100)$ & $1(100)$ \\
\hline & Intermediary & & & & & & & & \\
\hline & Resistant & & & & & & & & \\
\hline \multirow{3}{*}{ Nalidixic Acid } & Sensitive & $4(100)$ & $2(100)$ & $4(100)$ & $2(66.7)$ & $2(100)$ & $2(100)$ & $1(100)$ & $1(100)$ \\
\hline & Intermediary & & & & & & & & \\
\hline & Resistant & & & & $1(33.3)$ & & & & \\
\hline \multirow{3}{*}{ Tetracycline } & Sensitive & $4(100)$ & $2(100)$ & $3(75.0)$ & $3(100)$ & & $2(100)$ & $1(100)$ & $1(100)$ \\
\hline & Intermediary & & & $1(25.0)$ & & & & & \\
\hline & Resistant & & & & & $2(100)$ & & & \\
\hline \multirow{3}{*}{ Trimethoprim } & Sensitive & $4(100)$ & $2(100)$ & $4(100)$ & $3(100)$ & $2(100)$ & $2(100)$ & $1(100)$ & $1(100)$ \\
\hline & Intermediary & & & & & & & & \\
\hline & Resistant & & & & & & & & \\
\hline \multirow{3}{*}{ Nitrofurantoin } & Sensitive & $2(50.0)$ & $2(100)$ & $3(75.0)$ & $3(100)$ & & $2(100)$ & $1(100)$ & $1(100)$ \\
\hline & Intermediary & $1(25.0)$ & & $1(25.0)$ & & & & & \\
\hline & Resistant & $1(25.0)$ & & & & $2(100)$ & & & \\
\hline
\end{tabular}

Blank spaces indicate that no MIC value was determined for that concentration.

Note: No Escherichia coli isolates were detected in WC tap, kitchen knob and stove buttons, therefore no results were here included. 


\subsection{Domestic survey}

A survey (Table 11) was designed and some questions related with food safety and cleaning habits were administered to the persons responsible for the housework in each house, in attempts to correlate the microbiological results obtained for each domestic environment with the answers to the questionnaire applied at each house.

Demographic data including gender, age and educational background are given in Table 10. This survey constitutes a high number of female respondents (93.3\%) and only one man was responsible for housework (House 1). This ratio of female participants to male participants reflects the ratio of people responsible for housework and preparing food in Portugal. Related to age group we can see that the most predominant group refers to people between 51 and 60 years old (33.3\%) followed closely by those of more than 61 years of age (26.6\%). Education rates show that 5 in 15 respondents have primary instruction while 4 in 15 have a university degree. This may have great importance since the contamination found in each house was not always in accordance with the answers given.

Table 10 - Descriptive characteristics of the respondents

\begin{tabular}{cccc} 
House & \multicolumn{3}{c}{ Demographic characteristics } \\
\cline { 2 - 4 } & Gender & Age Group & Education \\
\hline 1 & Male & $\geq 61$ & University \\
2 & Female & $\geq 61$ & Technical course \\
3 & Female & $41-50$ & Primary \\
4 & Female & $31-40$ & University \\
5 & Female & $\geq 61$ & Primary \\
6 & Female & $41-50$ & University \\
7 & Female & $51-60$ & Primary \\
8 & Female & $31-40$ & University \\
9 & Female & $51-60$ & Primary \\
10 & Female & $51-60$ & Primary \\
11 & Female & $51-60$ & High school \\
12 & Female & $41-50$ & Junior high school \\
13 & Female & $51-60$ & Junior high school \\
14 & Female & $\geq 61$ & High school \\
15 & Female & $18-20$ & Technical course \\
\hline
\end{tabular}


Table 11 - Consumers cleaning habits and food safety knowledge in each house

\begin{tabular}{|c|c|c|c|c|c|c|c|c|c|c|c|}
\hline House & $\begin{array}{l}\text { Domestic } \\
\text { Animal }\end{array}$ & Hand washing & Door knob & Taps & $\begin{array}{l}\text { Kitchen } \\
\text { counter }\end{array}$ & $\begin{array}{c}\text { Stove } \\
\text { buttons }\end{array}$ & $\begin{array}{l}\text { Dishwasher } \\
\text { handle }\end{array}$ & $\begin{array}{l}\text { Refrigerator } \\
\text { handle }\end{array}$ & $\begin{array}{l}\text { Kitchen } \\
\text { cloth }\end{array}$ & $\begin{array}{l}\text { Cutting } \\
\text { board }\end{array}$ & $\begin{array}{c}\text { Food } \\
\text { safety } \\
\text { knowledge }\end{array}$ \\
\hline 1 & $\begin{array}{l}\text { Inside and out } \\
\text { within kitchen }\end{array}$ & $\begin{array}{l}\text { When using WC, } \\
\text { handling raw, } \\
\text { cooked or ready to } \\
\text { eat products }\end{array}$ & $\begin{array}{l}\text { No specific } \\
\text { frequency } \\
\text { with water } \\
\text { and } \\
\text { detergent }\end{array}$ & $\begin{array}{l}\text { After using } \\
\text { with } \\
\text { detergent }\end{array}$ & $\begin{array}{l}\text { After using } \\
\text { with } \\
\text { detergent }\end{array}$ & $\begin{array}{c}\text { After } \\
\text { using with } \\
\text { detergent }\end{array}$ & $\begin{array}{l}\text { No specific } \\
\text { frequency } \\
\text { with } \\
\text { detergent }\end{array}$ & $\begin{array}{c}\text { No specific } \\
\text { frequency } \\
\text { with water, } \\
\text { detergent } \\
\text { and } \\
\text { disinfectant }\end{array}$ & $\begin{array}{l}\text { Cloth, } \\
\text { "Vileda" } \\
\text { type and } \\
\text { sponge }\end{array}$ & $\begin{array}{l}\text { Separated } \\
\text { for meat } \\
\text { and fish }\end{array}$ & Yes \\
\hline 2 & $\begin{array}{l}\text { Inside and out } \\
\text { within kitchen }\end{array}$ & $\begin{array}{l}\text { When using WC, } \\
\text { handling raw, } \\
\text { cooked or ready to } \\
\text { eat products }\end{array}$ & $\begin{array}{l}\text { Every day } \\
\text { with } \\
\text { detergent }\end{array}$ & $\begin{array}{l}\text { Every day } \\
\text { with } \\
\text { disinfectant }\end{array}$ & $\begin{array}{l}\text { After using } \\
\text { with } \\
\text { disinfectant }\end{array}$ & $\begin{array}{c}\text { After } \\
\text { using with } \\
\text { detergent }\end{array}$ & $\begin{array}{l}\text { Every day } \\
\text { with } \\
\text { detergent }\end{array}$ & $\begin{array}{l}\text { Every day } \\
\text { with water }\end{array}$ & Cloth & $\begin{array}{l}\text { One board } \\
\text { only }\end{array}$ & Yes \\
\hline 3 & $\begin{array}{l}\text { Inside and out } \\
\text { within kitchen }\end{array}$ & $\begin{array}{l}\text { When using WC, } \\
\text { handling raw, } \\
\text { cooked or ready to } \\
\text { eat products }\end{array}$ & $\begin{array}{l}\text { No specific } \\
\text { frequency } \\
\text { with water } \\
\text { and } \\
\text { detergent }\end{array}$ & $\begin{array}{l}\text { After using } \\
\text { with water } \\
\text { and } \\
\text { detergent }\end{array}$ & $\begin{array}{l}\text { After using } \\
\text { with water } \\
\text { and } \\
\text { detergent }\end{array}$ & $\begin{array}{l}\text { After } \\
\text { using with } \\
\text { water and } \\
\text { detergent }\end{array}$ & N.A.** & $\begin{array}{l}\text { Once a week } \\
\text { with water } \\
\text { and } \\
\text { detergent }\end{array}$ & $\begin{array}{l}\text { Cloth, } \\
\text { "Vileda" } \\
\text { type and } \\
\text { sponge }\end{array}$ & $\begin{array}{l}\text { One board } \\
\text { only }\end{array}$ & No \\
\hline 4 & $\begin{array}{l}\text { Inside and out } \\
\text { within kitchen }\end{array}$ & $\begin{array}{l}\text { When using WC, } \\
\text { handling raw, } \\
\text { cooked or ready to } \\
\text { eat products }\end{array}$ & $\begin{array}{l}\text { No specific } \\
\text { frequency } \\
\text { with } \\
\text { detergent }\end{array}$ & $\begin{array}{l}\text { Every day } \\
\text { with } \\
\text { detergent }\end{array}$ & $\begin{array}{l}\text { After using } \\
\text { with } \\
\text { detergent }\end{array}$ & $\begin{array}{c}\text { Once a } \\
\text { week with } \\
\text { detergent }\end{array}$ & $\begin{array}{c}\text { No specific } \\
\text { frequency } \\
\text { with } \\
\text { detergent } \\
\text { and } \\
\text { disinfectant } \\
\end{array}$ & $\begin{array}{l}\text { No specific } \\
\text { frequency } \\
\text { with } \\
\text { detergent }\end{array}$ & $\begin{array}{l}\text { Cloth } \\
\text { and } \\
\text { sponge }\end{array}$ & $\begin{array}{l}\text { One board } \\
\text { only }\end{array}$ & Yes \\
\hline 5 & $\begin{array}{l}\text { Inside and out } \\
\text { within kitchen }\end{array}$ & $\begin{array}{l}\text { When using WC, } \\
\text { handling raw, } \\
\text { cooked or ready to } \\
\text { eat products }\end{array}$ & $\begin{array}{l}\text { Once a } \\
\text { week with } \\
\text { water }\end{array}$ & $\begin{array}{l}\text { Every day } \\
\text { with } \\
\text { detergent }\end{array}$ & $\begin{array}{l}\text { After using } \\
\text { with } \\
\text { detergent } \\
\text { and } \\
\text { disinfectant }\end{array}$ & N.A. ${ }^{*}$ & $\begin{array}{l}\text { Every day } \\
\text { with water }\end{array}$ & $\begin{array}{l}\text { Once a week } \\
\text { with water } \\
\text { and vinegar }\end{array}$ & $\begin{array}{l}\text { "Vileda" } \\
\text { type }\end{array}$ & $\begin{array}{l}\text { Separated } \\
\text { for meat, } \\
\text { fish, } \\
\text { vegetables, } \\
\text { cooked food } \\
\text { and bread }\end{array}$ & No \\
\hline 6 & $\begin{array}{l}\text { Inside and out } \\
\text { within kitchen }\end{array}$ & $\begin{array}{l}\text { When using WC, } \\
\text { handling raw, } \\
\text { cooked or ready to } \\
\text { eat products }\end{array}$ & $\begin{array}{c}\text { No specific } \\
\text { frequency } \\
\text { with } \\
\text { detergent } \\
\end{array}$ & $\begin{array}{l}\text { After using } \\
\text { with } \\
\text { detergent }\end{array}$ & $\begin{array}{l}\text { After using } \\
\text { with } \\
\text { detergent }\end{array}$ & $\begin{array}{c}\text { After } \\
\text { using with } \\
\text { detergent }\end{array}$ & $\begin{array}{c}\text { No specific } \\
\text { frequency } \\
\text { with } \\
\text { detergent } \\
\end{array}$ & $\begin{array}{l}\text { No specific } \\
\text { frequency } \\
\text { with } \\
\text { detergent } \\
\end{array}$ & $\begin{array}{l}\text { Cloth, } \\
\text { "Vileda" } \\
\text { type and } \\
\text { sponge }\end{array}$ & $\begin{array}{l}\text { One board } \\
\text { only }\end{array}$ & Yes \\
\hline 7 & $\begin{array}{l}\text { Inside and out } \\
\text { within kitchen }\end{array}$ & $\begin{array}{l}\text { When using WC } \\
\text { products }\end{array}$ & $\begin{array}{c}\text { Once a } \\
\text { week with } \\
\text { disinfectant }\end{array}$ & $\begin{array}{l}\text { Every day } \\
\text { with } \\
\text { detergent }\end{array}$ & $\begin{array}{l}\text { Every day } \\
\text { with } \\
\text { detergent }\end{array}$ & N.A.* & $\begin{array}{c}\text { Once a } \\
\text { month with } \\
\text { disinfectant }\end{array}$ & $\begin{array}{c}\text { Once a } \\
\text { month with } \\
\text { disinfectant }\end{array}$ & Cloth & $\begin{array}{l}\text { One board } \\
\text { only }\end{array}$ & Yes \\
\hline 8 & $\begin{array}{l}\text { Inside and out } \\
\text { within kitchen }\end{array}$ & $\begin{array}{l}\text { When using WC, } \\
\text { handling raw, } \\
\text { cooked or ready to } \\
\text { eat products }\end{array}$ & $\begin{array}{c}\text { Once a } \\
\text { month with } \\
\text { detergent }\end{array}$ & $\begin{array}{c}\text { Once a } \\
\text { month with } \\
\text { disinfectant }\end{array}$ & $\begin{array}{c}\text { Once a } \\
\text { week with } \\
\text { disinfectant }\end{array}$ & $\begin{array}{c}\text { Once a } \\
\text { week with } \\
\text { detergent }\end{array}$ & $\begin{array}{c}\text { Once a week } \\
\text { with } \\
\text { disinfectant }\end{array}$ & $\begin{array}{c}\text { Once a week } \\
\text { with } \\
\text { disinfectant }\end{array}$ & $\begin{array}{l}\text { "Vileda" } \\
\text { type }\end{array}$ & $\begin{array}{l}\text { One board } \\
\text { only }\end{array}$ & Yes \\
\hline
\end{tabular}

N.A. - House without domestic animal.

N.A. ${ }^{*}$ - House with ceramic hob.

N.A.** - House without dishwasher 
Table 11 (Continuation) - Consumers cleaning habits and food safety knowledge in each house

\begin{tabular}{|c|c|c|c|c|c|c|c|c|c|c|c|}
\hline House & $\begin{array}{c}\text { Domestic } \\
\text { Animal }\end{array}$ & Hand washing & Door knob & Taps & $\begin{array}{l}\text { Kitchen } \\
\text { counter }\end{array}$ & $\begin{array}{c}\text { Stove } \\
\text { buttons }\end{array}$ & $\begin{array}{l}\text { Dishwasher } \\
\text { handle }\end{array}$ & $\begin{array}{l}\text { Refrigerator } \\
\text { handle }\end{array}$ & $\begin{array}{l}\text { Kitchen } \\
\text { cloth }\end{array}$ & $\begin{array}{l}\text { Cutting } \\
\text { board }\end{array}$ & $\begin{array}{c}\text { Food } \\
\text { safety } \\
\text { knowledge }\end{array}$ \\
\hline 9 & $\begin{array}{l}\text { Inside and out } \\
\text { within kitchen }\end{array}$ & $\begin{array}{l}\text { When using WC, } \\
\text { handling raw, } \\
\text { cooked or ready to } \\
\text { eat products and } \\
\text { when she feels the } \\
\text { need }\end{array}$ & Never & $\begin{array}{c}\text { Once a } \\
\text { week with } \\
\text { water and } \\
\text { detergent }\end{array}$ & $\begin{array}{l}\text { After using } \\
\text { with water } \\
\text { and } \\
\text { detergent }\end{array}$ & $\begin{array}{l}\text { After using } \\
\text { with water } \\
\text { and } \\
\text { detergent }\end{array}$ & N.A.** & $\begin{array}{l}\text { Once a week } \\
\text { with water } \\
\text { and } \\
\text { detergent }\end{array}$ & $\begin{array}{l}\text { Cloth } \\
\text { and } \\
\text { "Vileda" } \\
\text { type }\end{array}$ & $\begin{array}{c}\text { One board } \\
\text { only }\end{array}$ & No \\
\hline 10 & $\begin{array}{l}\text { Inside and out } \\
\text { within kitchen }\end{array}$ & $\begin{array}{l}\text { When using WC, } \\
\text { handling raw, } \\
\text { cooked or ready to } \\
\text { eat products }\end{array}$ & $\begin{array}{c}\text { Once a } \\
\text { week with } \\
\text { water and } \\
\text { detergent }\end{array}$ & $\begin{array}{c}\text { After using } \\
\text { with water } \\
\text { and } \\
\text { detergent } \\
\end{array}$ & $\begin{array}{c}\text { After using } \\
\text { with water } \\
\text { and } \\
\text { detergent } \\
\end{array}$ & $\begin{array}{c}\text { After using } \\
\text { with water } \\
\text { and } \\
\text { detergent } \\
\end{array}$ & N.A. ${ }^{* *}$ & $\begin{array}{c}\text { Once a week } \\
\text { with water } \\
\text { and } \\
\text { detergent } \\
\end{array}$ & $\begin{array}{l}\text { Cloth } \\
\text { and } \\
\text { "Vileda" } \\
\text { type } \\
\end{array}$ & $\begin{array}{l}\text { One board } \\
\text { only }\end{array}$ & Yes \\
\hline 11 & $\begin{array}{l}\text { Inside and out } \\
\text { within kitchen }\end{array}$ & $\begin{array}{c}\text { When using WC, } \\
\text { handling raw, } \\
\text { cooked or ready to } \\
\text { eat products and } \\
\text { when she feels the } \\
\text { need }\end{array}$ & $\begin{array}{c}3 \text { in } 3 \\
\text { months with } \\
\text { detergent }\end{array}$ & $\begin{array}{l}\text { Every day } \\
\text { with } \\
\text { disinfectant }\end{array}$ & $\begin{array}{l}\text { After using } \\
\text { with } \\
\text { disinfectant }\end{array}$ & $\begin{array}{l}\text { After using } \\
\text { with } \\
\text { disinfectant }\end{array}$ & N.A.** & $\begin{array}{c}\text { Once a week } \\
\text { with } \\
\text { disinfectant }\end{array}$ & $\begin{array}{l}\text { "Vileda" } \\
\text { type }\end{array}$ & $\begin{array}{l}\text { One board } \\
\text { only }\end{array}$ & Yes \\
\hline 12 & $\begin{array}{l}\text { Inside and out } \\
\text { within kitchen }\end{array}$ & $\begin{array}{l}\text { When using WC, } \\
\text { handling raw, } \\
\text { cooked or ready to } \\
\text { eat products }\end{array}$ & $\begin{array}{c}\text { Once a } \\
\text { week with } \\
\text { disinfectant }\end{array}$ & $\begin{array}{l}\text { Every day } \\
\text { with } \\
\text { disinfectant }\end{array}$ & $\begin{array}{l}\text { Every day } \\
\text { with } \\
\text { disinfectant }\end{array}$ & $\begin{array}{l}\text { After using } \\
\text { with } \\
\text { detergent }\end{array}$ & $\begin{array}{c}\text { Once a } \\
\text { month with } \\
\text { disinfectant }\end{array}$ & $\begin{array}{l}\text { Every day } \\
\text { with } \\
\text { disinfectant }\end{array}$ & $\begin{array}{l}\text { "Vileda" } \\
\text { type }\end{array}$ & $\begin{array}{l}\text { One board } \\
\text { only }\end{array}$ & Yes \\
\hline 13 & $\begin{array}{l}\text { Inside and out } \\
\text { within kitchen }\end{array}$ & $\begin{array}{l}\text { When using WC } \\
\text { and handling ready } \\
\text { to eat products }\end{array}$ & $\begin{array}{c}\text { Once a } \\
\text { week with } \\
\text { disinfectant }\end{array}$ & $\begin{array}{l}\text { Every day } \\
\text { with } \\
\text { detergent }\end{array}$ & $\begin{array}{l}\text { After using } \\
\text { with } \\
\text { detergent }\end{array}$ & N.A.* & $\begin{array}{c}\text { Every day } \\
\text { with } \\
\text { detergent }\end{array}$ & $\begin{array}{c}\text { Once a week } \\
\text { with } \\
\text { detergent }\end{array}$ & $\begin{array}{l}\text { "Vileda" } \\
\text { type }\end{array}$ & $\begin{array}{l}\text { One board } \\
\text { only }\end{array}$ & Yes \\
\hline 14 & N.A. & $\begin{array}{l}\text { When using WC, } \\
\text { handling cooked or } \\
\text { ready to eat } \\
\text { products }\end{array}$ & $\begin{array}{c}\text { Once a } \\
\text { week with } \\
\text { detergent }\end{array}$ & $\begin{array}{l}\text { After using } \\
\text { with } \\
\text { detergent }\end{array}$ & $\begin{array}{l}\text { After using } \\
\text { with } \\
\text { detergent }\end{array}$ & $\begin{array}{l}\text { After using } \\
\text { with } \\
\text { disinfectant }\end{array}$ & N.A.** & $\begin{array}{c}\text { Once a week } \\
\text { with } \\
\text { disinfectant }\end{array}$ & Sponge & $\begin{array}{c}\text { Separated } \\
\text { for cooked } \\
\text { and raw } \\
\text { food }\end{array}$ & Yes \\
\hline 15 & $\begin{array}{l}\text { Inside and out } \\
\text { within kitchen }\end{array}$ & $\begin{array}{l}\text { When using WC } \\
\text { and handling raw } \\
\text { products }\end{array}$ & $\begin{array}{c}\text { Once a } \\
\text { month with } \\
\text { detergent }\end{array}$ & $\begin{array}{l}\text { Every day } \\
\text { with } \\
\text { detergent }\end{array}$ & $\begin{array}{l}\text { After using } \\
\text { with } \\
\text { detergent }\end{array}$ & $\begin{array}{l}\text { After using } \\
\text { with } \\
\text { detergent }\end{array}$ & $\begin{array}{c}\text { Every day } \\
\text { with } \\
\text { detergent }\end{array}$ & $\begin{array}{l}\text { Every day } \\
\text { with } \\
\text { detergent }\end{array}$ & Cloth & $\begin{array}{l}\text { One board } \\
\text { only }\end{array}$ & No \\
\hline
\end{tabular}

N.A. - House without domestic animal.

N.A. ${ }^{*}$ - House with ceramic hob.

N.A. ${ }^{* *}$ - House without dishwasher. 
Figures 5 to $\mathbf{8}$ exhibit foodborne pathogens found in the domestic setting for each house and in order to achieve some conclusions each house will be analysed separately with regard to the results of the questionnaire.

In House 1, no E. coli contamination was found and coagulase-positive Staphylococcus count showed levels lower than $10^{2} \mathrm{CFU} / \mathrm{swab}$. L. seeligeri was found in WC tap and knob while Enterobacteriaceae was detected in domestic animals' feet, cutting board, kitchen counter and kitchen cloth. Concerning antibiotic resistance, Enterobacteriaceae strains from domestic animal showed resistance to trimethoprim ( $\mathrm{MIC}>128 \mu \mathrm{g} / \mathrm{mL}$ ), to ampicillin from cutting board (MIC of $64 \mu \mathrm{g} / \mathrm{mL}$ ) and kitchen counter (MIC of $32 \mu \mathrm{g} / \mathrm{mL}$ ). One Salmonella isolate from domestic animal presented resistance to nitrofurantoin (MIC of $128 \mu \mathrm{g} / \mathrm{mL}$ ).

Concerning the survey, and comparing with food pathogens presence, we can conclude that domestic animals which are usually in the kitchen area may increase the contamination hazard to surfaces and food. Cleaning the kitchen counter with detergent after use doesn't seem to be effective and the presence of antibiotic-resistant Enterobacteriaceae strains on the cutting board may point to incorrect cleaning/disinfection.

Within House 2, no E. coli or Listeria spp. contamination was found and coagulase-positive Staphylococcus count showed levels lower than $10^{2} \mathrm{CFU} / \mathrm{swab}$. Enterobacteriaceae (Salmonella spp.) was detected in kitchen tap and kitchen cloth. Concerning antibiotic resistance, Salmonella strains showed high resistance to ampicillin only from the kitchen cloth (MIC of $256 \mu \mathrm{g} / \mathrm{mL}$ ).

Concerning the survey, and comparing with food pathogens presence, we can conclude that in this house the problem lies in the kitchen towel material used (cloth) which can shelter numerous bacteria.

At House 3, Listeria spp. was absent and low rates $\left(<10^{2} \mathrm{CFU} / \mathrm{swab}\right)$ of coagulase-positive Staphylococcus and E. coli were found. Several enterobacteria isolates were found on domestic animal, WC knob, Kitchen tap and counter, cutting board and kitchen cloth. Relating to antibiotic resistance, Salmonella strains from the cutting board, presented multiple resistance, specifically to ampicillin (MIC of $64 \mu \mathrm{g} / \mathrm{mL}$ ), chloramphenicol (MIC of $32 \mu \mathrm{g} / \mathrm{mL}$ ), tetracycline (MIC of $1286 \mu \mathrm{g} / \mathrm{mL}$ ) and nitrofurantoin (MIC of $128 \mu \mathrm{g} / \mathrm{mL}$ ). Enterobacteriaceae isolated from kitchen tap showed nitrofurantoin resistance (MIC of $64 \mu \mathrm{g} / \mathrm{mL}$ ) and ampicillin resistance was detected in $E$. coli isolated from the kitchen cloth (MIC of $32 \mu \mathrm{g} / \mathrm{mL}$ ).

With reference to the survey, multi-resistant Salmonella found in the single cutting board used seems to be the problem in this house.

House 4, also no Listeria was found, low rates (< $\left.10^{2} \mathrm{CFU} / \mathrm{swab}\right)$ of coagulase-positive Staphylococcus were found and $E$. coli were found on the kitchen counter ( $\left.10^{3} \mathrm{CFU} / \mathrm{swab}\right)$. Kitchen tap, counter, refrigerator and dishwasher handle were found to be highly contaminated with Enterobacteriaceae $\left(10^{3}\right.$ to $\left.10^{4} \mathrm{CFU} / \mathrm{swab}\right)$. Ampicillin resistance was established in Salmonella from the kitchen tap (MIC of $32 \mu \mathrm{g} / \mathrm{mL}$ ) and Enterobacteriaceae found on the dishwasher handle were 
resistant to nitrofurantoin (MIC of $128 \mu \mathrm{g} / \mathrm{mL}$ ). Resistance to ampicillin and nitrofurantoin were detected in E. coli isolated from the kitchen counter (MIC of $256 \mu \mathrm{g} / \mathrm{mL}$ and MIC of $128 \mu \mathrm{g} / \mathrm{mL}$, respectively). Concerning the domestic survey, special attention was given to $E$. coli found on the counter, usually cleaned after use with detergent, which doesn't seem to be effective in eradication of bacteria. Also taps that were declared to be cleaned every day with detergent presented Salmonella contamination. Related to dishwasher handle no specific frequency in cleaning may explain the presence of enteric bacteria.

In House 5, low rates $\left(<10^{2} \mathrm{CFU} / \mathrm{swab}\right)$ of coagulase-positive Staphylococcus were found, kitchen counter and dishwasher handle presented E. coli contamination $\left(10^{2}\right.$ to $\left.10^{3} \mathrm{CFU} / \mathrm{swab}\right)$ while no Listeria was found. Enterobacteria were identified on WC knob, kitchen counter, dishwasher handle and kitchen cloth but no resistance to antibiotics was determined.

Regarding the survey, although after using kitchen counter cleaning with detergent and disinfectant $E$. coli was detected as well as on the dishwasher handle which was stated to be cleaned every day with water. Apparently this kind of action showed no efficient results and more actions should be taken.

Inside House 6, high rates of coagulase-positive Staphylococcus were detected $\left(10^{2}\right.$ to $10^{5} \mathrm{CFU} / \mathrm{swab}$ ) but no E. coli was detected. Concerning Listeria presence, in fact L. innocua and L. grayi were found in kitchen tap and kitchen counter, in that order. Domestic animal $\left(10^{4} \mathrm{CFU} / \mathrm{swab}\right)$ and kitchen tap $\left(10^{3}\right.$ CFU/swab) proved to be contaminated with enterobacteria but only pets paws isolates showed resistance to ampicillin (MIC of $32 \mu \mathrm{g} / \mathrm{mL}$ ).

The survey informed us that domestic animals that are usually in the kitchen area may represent a hazard due to cross-contamination while taps after use and cleaning with detergent also does not seem to be effective.

At House 7, Listeria spp. was found in domestic animals' feet while coagulase-positive Staphylococcus and $E$. coli were detected at low rates $\left(<10^{2} \mathrm{CFU} / \mathrm{swab}\right)$. Enterobacteriaceae contamination was revealed to be high $\left(10^{2}\right.$ to $\left.10^{5} \mathrm{CFU} / \mathrm{swab}\right)$ on the kitchen tap, refrigerator and dishwasher handles and kitchen cloth, although only ampicillin resistance was found in $E$. coli isolates from the kitchen tap (MIC of $64 \mu \mathrm{g} / \mathrm{mL}$ ) and refrigerator handle (MIC of $128 \mu \mathrm{g} / \mathrm{mL}$ ).

In relation to the questionnaire, taps daily cleaning with detergent and monthly disinfection of refrigerator and dishwasher handle doesn't seem to be effective or this kind of actions aren't really taken in to action.

For House 8, the kitchen counter proved to be highly contaminated with coagulase-positive Staphylococcus but no Listeria was found. WC and kitchen knobs presented contamination with Enterobacteriaceae while cutting board and kitchen cloth were contaminated with $E$. coli but none of them showed antibiotic resistance.

The survey demonstrated that monthly knob cleaning is not enough to eliminate these foodborne pathogens and that different cutting boards should be used for different kinds of food. 


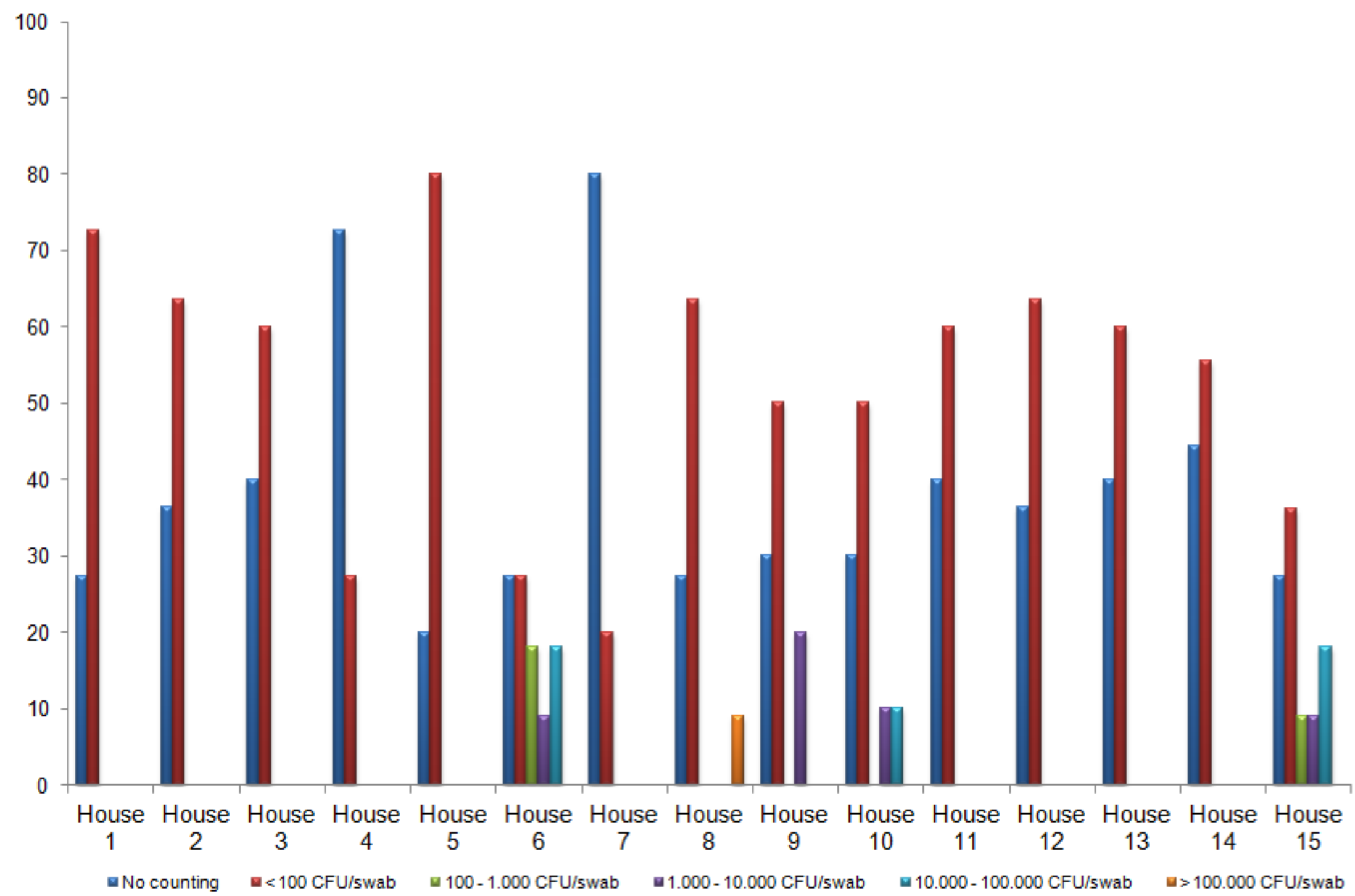

Figure 5 - Coagulase-positive Staphylococcus count (\%) by house. 


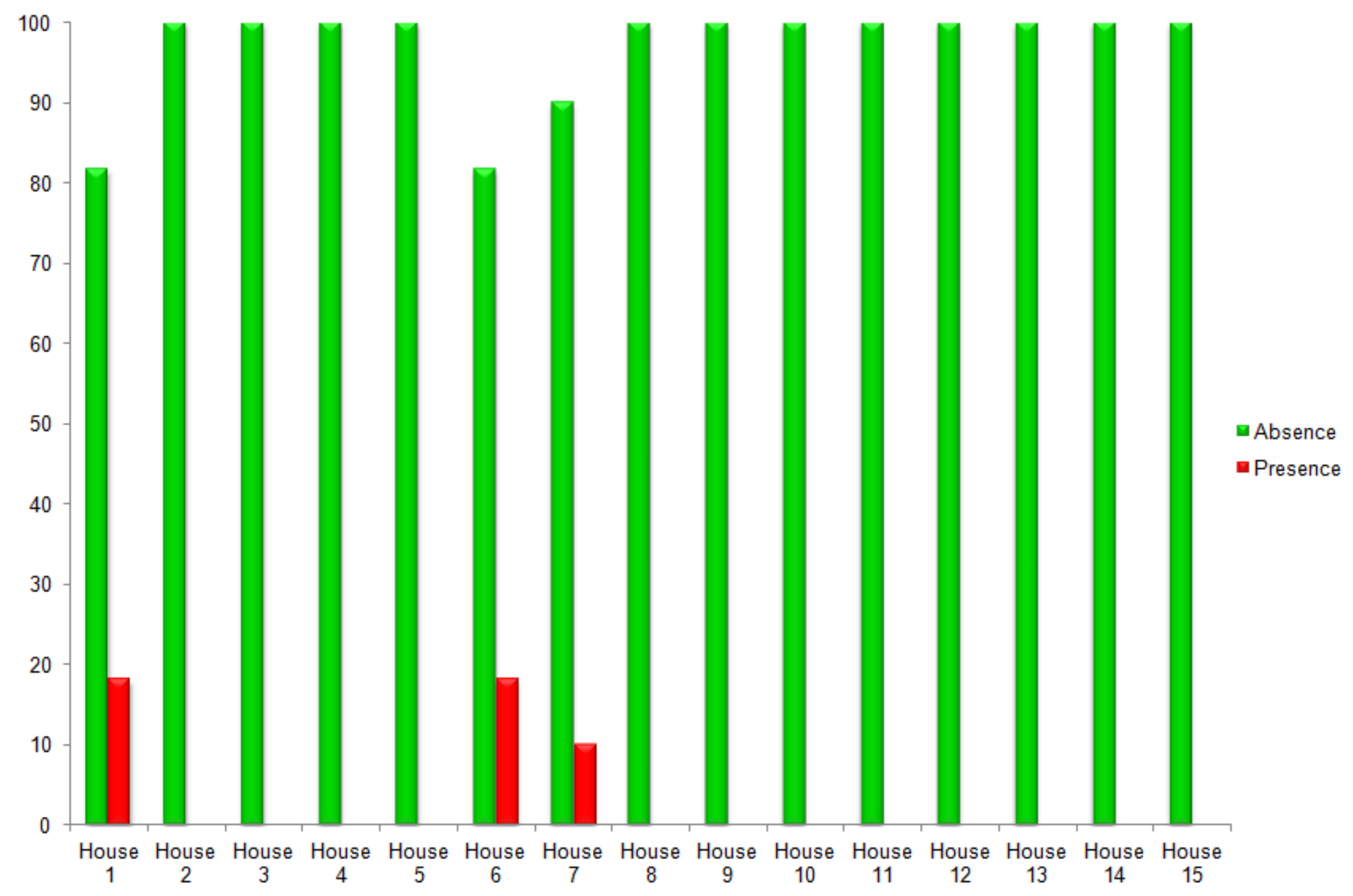

Figure 6 - Listeria spp. detection (\%) by house. 


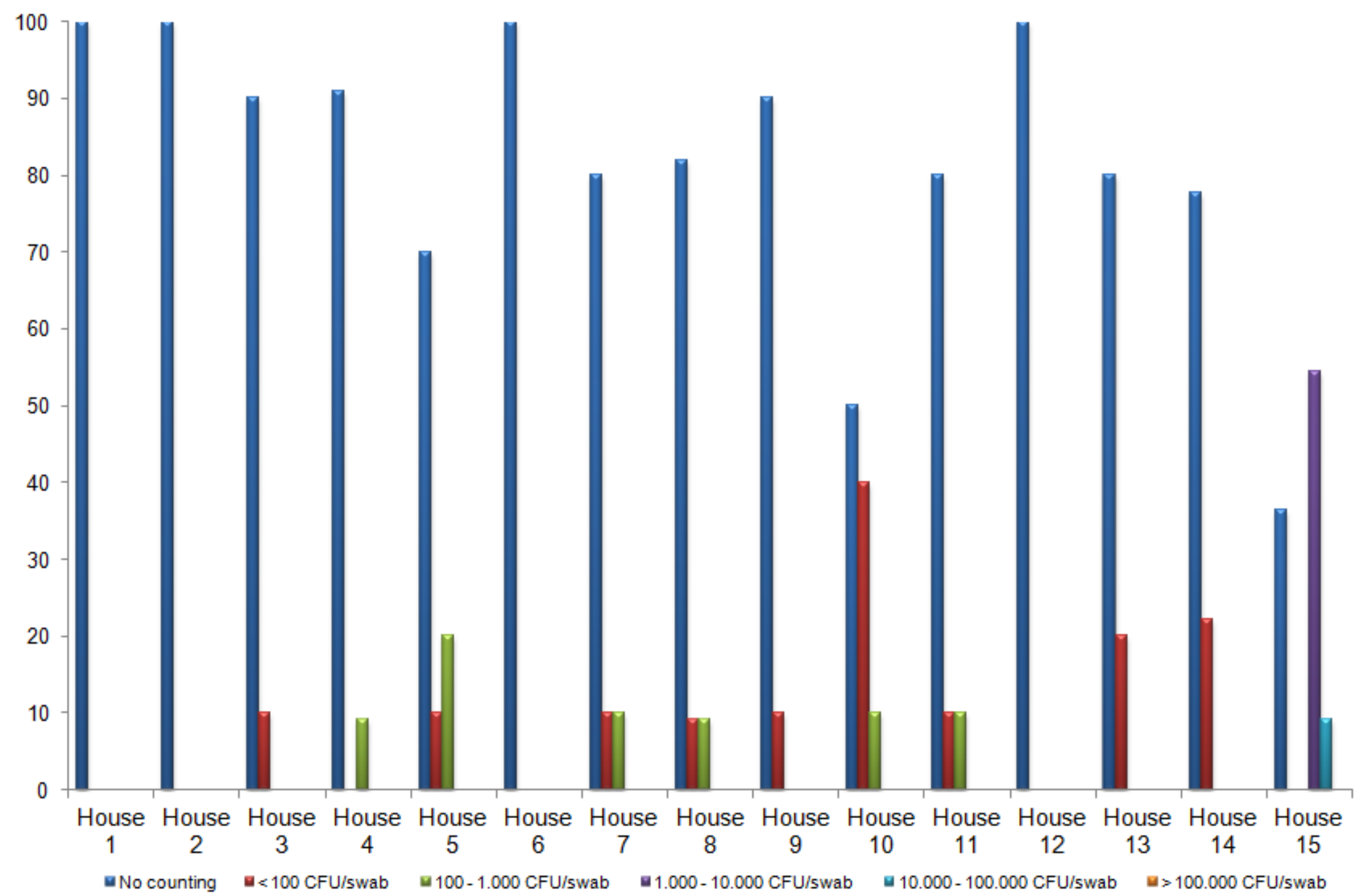

Figure 7 - Escherichia coli count (\%) by house. 


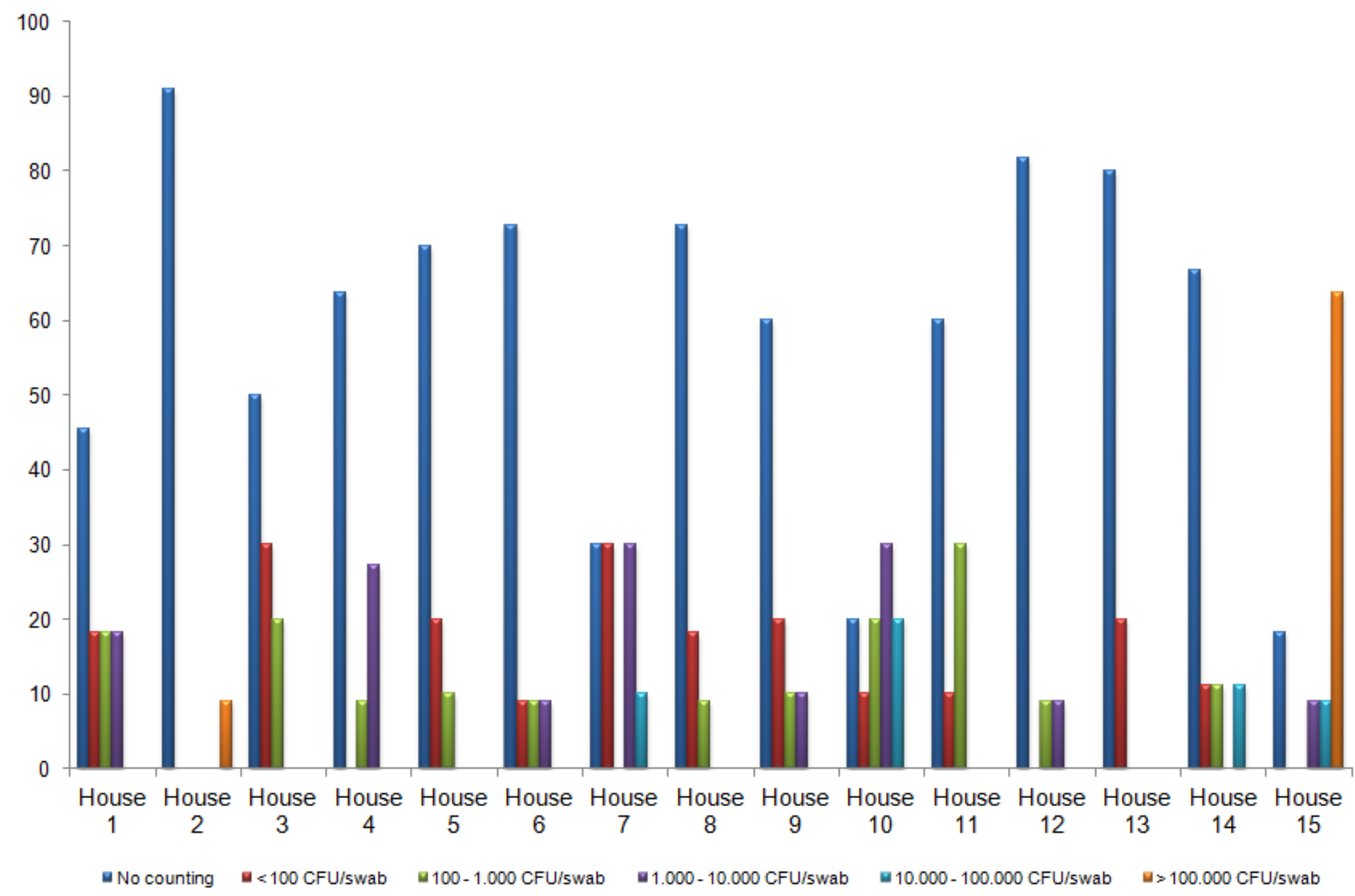

Figure 8 - Enterobacteriaceae count (\%) by house. 
In House 9, coagulase-positive Staphylococcus were present ( $\left.10^{4} \mathrm{CFU} / \mathrm{swab}\right)$, especially on stove buttons and cutting board, and $E$. coli contamination of kitchen knob ranged up to $10^{3} \mathrm{CFU} /$ swab while no Listeria was detected. Kitchen knob, counter and cloth demonstrated enteric contamination (ranging from $10^{2}$ to $10^{4} \mathrm{CFU} / \mathrm{swab}$ ) and ampicillin resistance was found in isolates from the knob (MIC of $32 \mu \mathrm{g} / \mathrm{mL}$ ) and counter (MIC of $32 \mu \mathrm{g} / \mathrm{mL}$ ).

Knobs were assumed never to be cleaned, which can help explain E. coli contamination and antibiotic resistance, while kitchen counter cleaning is made using water and detergent.

House 10, shows contamination by coagulase-positive Staphylococcus ( $10^{4}$ to $\left.10^{5} \mathrm{CFU} / \mathrm{swab}\right)$ and by $E$. coli $\left(10^{3} \mathrm{CFU} / \mathrm{swab}\right)$ although Listeria was not present. In this house enterobacteria seems to be widely spread, showing contamination levels ca. $10^{5} \mathrm{CFU} / \mathrm{swab}$, contaminating kitchen knob, kitchen tap, kitchen counter, cutting board, refrigerator handle, stove buttons and kitchen cloth. Resistance to ampicillin was found in Enterobacteriaceae isolated from kitchen knob (MIC of $64 \mu \mathrm{g} / \mathrm{mL}$ ), kitchen tap (MIC of $64 \mu \mathrm{g} / \mathrm{mL}$ ), cutting board (MIC of $128 \mu \mathrm{g} / \mathrm{mL}$ ) and stove buttons (MIC of $64 \mu \mathrm{g} / \mathrm{mL}$ ) while resistant isolates of $E$. coli were detected in WC tap (MIC of $32 \mu \mathrm{g} / \mathrm{mL}$ ), cutting board (MIC of $128 \mu \mathrm{g} / \mathrm{mL}$ ) and kitchen cloth (MIC of $256 \mu \mathrm{g} / \mathrm{mL})$.

Tap and stove buttons were said to be cleaned after use and knobs once a week all of them using water and detergent which does not seem to be sufficient. A single cutting board is used for all types of food in this house meaning that cross-contamination can occur, while kitchen cloth, either fabric or "Vileda" type, may hold high levels of contamination.

At House 11, low rates of coagulase-positive Staphylococcus were found ( $<10^{2} \mathrm{CFU} / \mathrm{swab}$ ) and no Listeria was detected. Regarding E. coli, $10^{3} \mathrm{CFU} / \mathrm{swab}$ were detected on the cutting board but enteric pathogens were found on other surfaces, namely kitchen tap, kitchen counter and kitchen cloth. Enterobacteriaceae and E. coli resistant to ampicillin, were proven to exist in kitchen tap (MIC of 256 $\mu \mathrm{g} / \mathrm{mL}$ and MIC of $512 \mu \mathrm{g} / \mathrm{mL}$, correspondingly) while Salmonella spp. isolated from the kitchen counter presented resistance to nalidixic acid (MIC of $32 \mu \mathrm{g} / \mathrm{mL}$ ).

In this house survey, taps were cleaned every day with disinfectant as well as kitchen counter which is cleaned after use although this routine does not appear to be effective. A single cutting board is in use and "Vileda" type kitchen cloth is used.

Within House 12, no E. coli nor Listeria were found and coagulase-positive Staphylococcus were found in low rates $\left(<10^{2} \mathrm{CFU} / \mathrm{swab}\right)$. Despite this, high levels of enterobacteria were detected $\left(10^{3}\right.$ to $10^{4}$ $\mathrm{CFU} / \mathrm{swab}$ ) on the WC tap, kitchen counter and cloth. Resistance to ampicillin was identified for isolates from the WC tap and kitchen counter (MIC of $128 \mu \mathrm{g} / \mathrm{mL}$ and $32 \mu \mathrm{g} / \mathrm{mL}$, respectively) and those from the kitchen cloth presented resistance to nitrofurantoin (MIC of $128 \mu \mathrm{g} / \mathrm{mL}$ ).

This is in disagreement with the survey which indicates that both taps and counter are daily cleaned with disinfectant. The use of "Vileda" type kitchen cloth, which is wet most of the time, may be the cause of enteric bacteria presence. 
About House 13, also no Listeria was found although E. coli and coagulase-positive Staphylococcus showed low rates $\left(<10^{2} \mathrm{CFU} / \mathrm{swab}\right)$ of contamination. In relation to Enterobacteriaceae, these bacteria were detected on the dishwasher handle, cutting board and kitchen cloth but in low numbers $\left(<10^{2}\right.$ $\mathrm{CFU} / \mathrm{swab}$ ) even though multi-resistance was found. E. coli found on the dishwasher handle and kitchen cloth isolates presented high resistance to ampicillin (MIC of $256 \mu \mathrm{g} / \mathrm{mL}$ and $512 \mu \mathrm{g} / \mathrm{mL}$ ), chloramphenicol (both with MIC of $256 \mu \mathrm{g} / \mathrm{mL}$ ), nalidixic acid (both with MIC > $512 \mu \mathrm{g} / \mathrm{mL}$ ) and tetracycline (both with MIC of $256 \mu \mathrm{g} / \mathrm{mL})$.

These findings are not consistent with the survey where dishwasher handle was stated to be cleaned everyday with detergent. Although a single cutting board is used for different types of food the biggest problem is "Vileda" type of kitchen cloth that holds multi-resistant E. coli.

In House 14, as in the previous house, no Listeria was found although E. coli and coagulase-positive Staphylococcus showed low rates $\left(<10^{2} \mathrm{CFU} / \mathrm{swab}\right)$ of contamination. High rates of enteric bacteria were detected $\left(10^{3}\right.$ to $\left.10^{5} \mathrm{CFU} / \mathrm{swab}\right)$ namely on the cutting board, stove buttons and kitchen cloth. E. coli strains were determined to be resistant to ampicillin isolated from the cutting board (MIC of $32 \mu \mathrm{g} / \mathrm{mL}$ ) and kitchen cloth (MIC of $256 \mu \mathrm{g} / \mathrm{mL}$ ).

Once more this is not in accordance with the survey, where statements were made concerning daily cleaning of stove buttons with disinfectant. A single cutting board is used and sponge kind of kitchen cloth is obviously a good wet material for bacterial dissemination.

Inside House 15 several pathogens were detected in high levels $\left(10^{3}\right.$ to $\left.10^{5} \mathrm{CFU} / \mathrm{swab}\right)$, like coagulasepositive Staphylococcus and E. coli but no Listeria spp. was found. Concerning enteric contamination, this was the only house that presented extremely high rates of contamination (> $10^{5} \mathrm{CFU} / \mathrm{swab}$ ) on at least seven surfaces, namely domestic animal paws, kitchen tap, kitchen counter, refrigerator and dishwasher handles, stove buttons and kitchen cloth. Multiple resistance to ampicillin (MIC of $128 \mu \mathrm{g} / \mathrm{mL}$ ) and nitrofurantoin (MIC of $128 \mu \mathrm{g} / \mathrm{mL}$ ) was found in $E$. coli isolated from kitchen counter. Stove buttons, contaminated with E. coli, also presented multiple resistance to ampicillin (MIC of $64 \mu \mathrm{g} / \mathrm{mL}$ ) and tetracycline (MIC of $16 \mu \mathrm{g} / \mathrm{mL}$ ). Enterobacteriaceae isolates from the kitchen cloth were found to be resistant to both ampicillin (MIC of $32 \mu \mathrm{g} / \mathrm{mL}$ ) and nitrofurantoin (MIC of $128 \mu \mathrm{g} / \mathrm{mL}$ ) while from stove buttons, strains were resistant to ampicillin (MIC of $32 \mu \mathrm{g} / \mathrm{mL}$ ).

From all that has been stated it seems hard to believe that taps are cleaned every day with detergent or that both refrigerator and dishwasher handles are daily cleaned with detergent. Furthermore, stove buttons and kitchen counter presented high enteric contamination and are stated to be cleaned after use with detergent. Kitchen cloth fabric and domestic animals in the kitchen area may contribute considerably to cross-contamination once high contamination rates are present.

Overall, consumers education or food knowledge does not give the impression that better or worse good food handling practices in a domestic environment are used. Therefore it seems necessary that enhanced information and training is given in order to develop improved behaviours in the domestic setting. 


\section{Conclusion}

Taking into account all the obtained results it seems fundamental to comment that, in practice, cleaning the house is not the only important issue, knowing how to prevent contamination is just as crucial. In all cases "prevention is better than cure".

According to results presented in this study and those previously published (Rusin et al., 1998; Beumer and te Giffel, 1999; Scott, 2001; Adiga et al., 2012;), the home is a multifunctional setting in which there is a constant transfer of pathogens into and out of the home. In the domestic setting various surfaces can harbour pathogenic organisms, thus being a potential source of food poisoning, possibly through crosscontamination. Potential pathogens from sources such as raw foods, persons, and animals can be transferred between inanimate and animate surfaces through either direct or indirect contact (Scott, 1999). The major factor contributing to foodborne illness, especially in the home, is the mishandling of food in the final preparation steps since consumers are not aware of their role in food poisoning. Epidemiological data suggests the home is a significant point of origin for food poisoning occurrences (Redmond and Griffith, 2003) and therefore it is important for consumers to be responsible for safe food-handling in their homes. Infectious diseases are a threat to public health and are often transmitted in the domestic setting. However, infectious disease spread in the home, as elsewhere, can be prevented through an effective hygiene strategy (Larson, 1999). Maintaining strictly hygienic practices, limiting cross-contamination, and regular cleaning of contact surfaces with detergents, hot water and sanitizers is indispensable to prevention of foodborne contamination.

This study illustrates that many pathogenic Enterobacteriaceae have developed resistance to frequently used antimicrobial agents, often presenting resistance to multiple antimicrobial classes simultaneously. Other recent studies have also reported on the declining activity of several antimicrobial groups against the Enterobacteriaceae including the fluoroquinolones (Levy, 2005; Rhomberg et al., 2006; DiPersio and Dowzicky, 2007; Denton, 2007). In contrast to the early decades following the introduction of antibiotics, today's environments - hospitals, homes and communities - are replete with drug resistance genes, among both pathogens and commensals (Levy, 1998). Therefore, and as has been proved in this study, antibiotic resistance including multi-resistance, is not restricted to hospital environments since such strains can be found quite frequently in the domestic environment.

A consumer survey can be a useful instrument to collect information which yields concrete evidence for a requirement for educational measures. Some consumers do not have the necessary competence in handling food hygienically, and therefore public education is perceived as a key factor in improving food safety practices in the home and food preparers and consumers would benefit from home safety education, including information about temperature control, correct home food preparation practices and cross-contamination (Pfau and Piekarski, 2003; Wilcock et al., 2004). 
Overall, the information obtained from our survey revealed an urgent need for consumer education in Portugal regarding safe food handling practices and cleaning habits. It's also important to refer that most answers given in the questionnaire were not consistent with analytic data obtained in this study. 


\section{Future Work}

It was a good challenge to perform this work by the fact that little information exists about real food safety and antibiotic susceptibility in the domestic environment. Therefore, several interesting work could be done such as:

- Identification at species level of all Enterobacteriaceae isolates that were mainly identified at genus level, by biochemistry or genotypic tests or appropriate PCR techniques;

- Identification and virulence factors of Staphylococcus aureus by PCR assay;

- Define an optimized protocol for Campylobacter spp. detection in order to increase the possibility of isolation in samples from the domestic environment;

- Provide information to consumers regarding better food handling practices and cleaning habits through education in Portugal;

- Perform an interdisciplinary investigation of microbial hazards during food preparation where domestic food safety practices can be evaluated in situo. 


\section{References}

- Aarestrup, F. M. 2000. Occurrence, selection and spread of resistance to antimicrobial agents used for growth promotion for food animals in Denmark. APMIS Supplementum 101: 1-48.

- Adiga I, L SK, Mustaffa MB, Bismi NB, Yusof NB, Ibrahim NB, Md Nor NB. Bacterial Contamination in the Kitchen: Could It Be Pathogenic. WebmedCentral: International Journal of Medicine and Molecular Medicine 2012;3(4):WMC003256.

- Antunes, P., Reu, C. et al. 2003. Incidence of Salmonella from poultry products and their susceptibility to antimicrobial agents. International Journal of Food Microbiology 82(2): 97-103.

- Arbuthnott, J. P., Coleman, D. C. et al. 1990. Staphylococcal toxins in human disease. Society for Applied Bacteriology Symposium Series 19: 101S-107S.

- Ak, Nese O., Cliver, Dean O. et al. 1994. Cutting boards of plastic and wood contaminated experimentally with bacteria. Journal of Food Protection 57(1): 16-22.

- Azevedo, I., Regado, M. et al. 2005. Incidence of Listeria spp. in domestic refrigerators in Portugal. Food Control 16: 121-124.

- Barker, J. and Bloomfield, S. F. 2000. Survival of Salmonella in bathrooms and toilets in domestic homes following salmonellosis. Journal of Applied Microbiology 89(1): 137-144.

- Beumer, R. R., Giffel, M. C. et al. 1996. Listeria species in domestic environments. Epidemiology and Infection 117: 437-442.

- Beumer, R. R. and Giffel, M. C. 1999. Pathogens in domestic kitchens: facts and fiction. In: Tuijtelaars, A.C.J., Samson, R.A., Rombouts, F.M., Notermans, S. (Eds.), Food Microbiology and Food Safety into the Next Millennium. Zeist, The Netherlands, pp. 345 - 347.

- Beumer, R. R. and Kusumaningrum, H. 2003. Kitchen hygiene in daily life. International Biodeterioration \& Biodegradation 51: 299-302.

- Beutin, L. 1999. Escherichia coli as a pathogen in dogs and cats. Veterinary Research 30: 285-298.

- Blackman, I. C. and Frank, J. F. 1996. Growth of Listeria monocytogenes as a biofilm on various foodprocessing surfaces. Journal of Food Protection 59: 827-831.

- Bradford, M. A., Humphrey, T. J. et al. 1997. The cross-contamination and survival of Salmonella enteritidis PT4 on sterile and non-sterile foodstuffs. Letters in Applied Microbiology 24(4): 261-264.

- Bolton, D. J., and Maunsell, B. 2006. Guidelines for Domestic Kitchen Food Safety. Ashtown, Dublin, Republic of Ireland.

- Bonten, M., Stobberingh, E. et al. 1992. Antibiotic resistance of Escherichia coli in fecal samples of healthy people in two different areas in an industrialized country. Infection 20(5): 258-262.

- Bywater, R., Deluyker, H. et al. 2004. A European survey of antimicrobial susceptibility among zoonotic and commensal bacteria isolated from food-producing animals. Journal of Antimicrobial Chemotherapy 54(4): 744-754.

- Chomarat, M. 2000. Resistance of bacteria in urinary tract infections. International Journal of Antimicrobial Agents 16(4): 483-487. 
- Clinical and Laboratory Standards Institute. Performance Standards for Antimicrobial Susceptibility Testing; Seventeenth Informational Supplement. CLSI document M100-S17 [ISBN 1-56238-625-5]. Clinical and Laboratory Standards Institute, 940 West Valley Road, Suite 1400, Wayne, Pennsylvania 19087- 1898 USA, 2007.

- Cobeljic, M., Dimic, B. et al. 2005. The prevalence of Shiga toxin-producing Escherichia coli in domestic animals and food in Serbia. Epidemiology and Infection 133(2): 359-366.

- Cormican, M., Buckley, V. et al. 2001. Antimicrobial resistance in Escherichia coli isolates from turkeys and hens in Ireland. Journal of Antimicrobial Chemotherapy 48(4): 587-588.

- Curtis, V., Biran, A. et al. 2003. Hygiene in the home: relating bugs and behaviour. Social Science and Medicine 57(4): 657-672.

- Davis J. G., Blake, J. R. et al. 1968. A survey of the hygienic conditions of domestic dish-cloths and teatowels. The Medical Officer 120: 29-32.

- de Boer, E. and Hahné, M. 1990. Cross-contamination with Campylobacter jejuni and Salmonella spp. from raw chicken products during food preparation. Journal of Food Protection 53(12): 1067- 1068.

- de Wit, J. C., Broekhuizen, G. et al. 1979. Cross-contamination during the preparation of frozen chickens in the kitchen. The Journal of Hygiene 83(1): 27-32.

- Denton, M. 2007. Enterobacteriaceae. International Journal of Antimicrobial Agents 29 Suppl 3: S9S22.

- DiPersio, J. R. and Dowzicky, M. J. 2007. Regional variations in multidrug resistance among Enterobacteriaceae in the USA and comparative activity of tigecycline, a new glycylcycline antimicrobial. International Journal of Antimicrobial Agents 29(5): 518-527.

- Edrington, T. S., Long, M. et al. 2009. Prevalence and antimicrobial resistance profiles of Escherichia coli O157:H7 and Salmonella isolated from feedlot lambs. Journal of Food Protection 72(8): 17131717.

- Farber, J. M. and Losos, J. Z. 1988. Listeria monocytogenes: a foodborne pathogen. Canadian Medical Association Journal 138(5): 413-418.

- Farber, J. M. and Peterkin, PI. 1991. Listeria monocytogenes: a foodborne pathogen. Microbiological Reviews 55: 476-511.

- Finch, J. E., Prince, J. et al. 1978. A bacteriological survey of the domestic environment. Journal of Applied Bacteriology 45(3): 357-364.

- Fischer, A. R., Frewer, L. J., and Nauta, M. J. 2006. Toward Improving Food Safety in the Domestic Environment: A Multi-Item Rasch Scale for the Measurement of the Safety Efficacy of Domestic FoodHandling Practices. Risk Analysis 26(5):1323-1338.

- Fluckey, W. M., Loneragan, W. G. et al. 2007. Antimicrobial drug resistance of Salmonella and Escherichia coli isolates from cattle feces, hides, and carcasses. Journal of Food Protection 70(3): 551-556. 
- Fritsche, T. R., Strabala, P. A. et al. 2005. Activity of tigecycline tested against a global collection of Enterobacteriaceae, including tetracycline-resistant isolates. Diagnostic Microbiology and Infectious Disease 52(3): 209-213.

- Gandhi, M. and Chikindas, M. L. 2007. Listeria: A foodborne pathogen that knows how to survive. International Journal of Food Microbiology 113(1): 1-15.

- Gerba, C. P., Wallis, C. et al. 1975. Microbiological hazards of household toilets: droplet production and the fate of residual organisms. Applied Microbiology 30(2): 229-237.

- Gorman, R., Bloomfield, S. et al. 2002. A study of cross-contamination of food-borne pathogens in the domestic kitchen in the Republic of Ireland. International Journal of Food Microbiology 76(1-2): 143150.

- Guardabassi, L. Schwarz, S. et al. 2004. Pet animals as reservoirs of antimicrobial-resistant bacteria. Journal of Antimicrobial Chemotherapy 54: 321-332.

- Guerra, B., Junker, E. et al. 2003. Phenotypic and genotypic characterization of antimicrobial resistance in German Escherichia coli isolates from cattle, swine and poultry. Journal of Antimicrobial Chemotherapy 52(3): 489-492.

- Gupta, K., Hooton, T. M. et al. 2001. Increasing antimicrobial resistance and the management of uncomplicated community-acquired urinary tract infections. Annals of Internal Medicine 135(1): 41-50.

- Hleba, L., Kačániová, M. et al. 2011. Antibiotic resistance of Enterobacteriaceae genera and Salmonella spp., Salmonella enterica ser. typhimurium and enteriditis isolated from milk, cheese and othe dairy products from conventional farm in Slovakia. Journal of Microbiology, Biotechnology and Food Sciences 1(1): 1-20.

- Hooton, T. M., Winter, C. et al. 1995. Randomized comparative trial and cost analysis of 3-day antimicrobial regimens for treatment of acute cystitis in women. Journal of the American Medical Association 273(1): 41-45.

- Hooton, T. M. and Stamm, W. E. 1997. Diagnosis and treatment of uncomplicated urinary tract infection. Infectious Disease Clinics of North America 11(3): 551-581.

- Humphrey, T. J., Martin, K. W. et al. 1994. Contamination of hands and work surfaces with Salmonella enteritidis PT4 during the preparation of egg dishes. Epidemiology and Infection 113(3): 403-409.

- Humphrey, T. J., Martin, K. W. et al. 2001. Campylobacter spp. in the kitchen: spread and persistence. Symposium Series (Society for Applied Microbiology) 30: 115S-120S.

- ISO 6888-1 (1999). Microbiology of food and animal feeding stuffs - Horizontal method for the enumeration of coagulase-positive staphylococci (Staphylococcus aureus and other species) - Part 1: Technique using Baird-Parker agar medium. International Organization for Standardization, Geneva, Switzerland.

- ISO 10272-1 (2006). Microbiology of food and animal feeding stuffs - Horizontal method for detection and enumeration of Campylobacter spp. - Part 1: Detection method. International Organization for Standardization, Geneva, Switzerland. 
- ISO 11290-1 (1996). Microbiology of food and animal feeding stuffs - Horizontal method for the detection and enumeration of Listeria monocytogenes - Part 1: Detection method. International Organization for Standardization, Geneva, Switzerland.

- ISO 16649-2 (2001). Microbiology of food and animal feeding stuffs - Horizontal method for the enumeration of beta-glucuronidase-positive Escherichia coli - Part 2: Colony-count technique at 44 degrees C using 5-bromo-4-chloro-3-indolyl beta-D-glucuronide. International Organization for Standardization, Geneva, Switzerland.

- ISO 21528-2 (2004). Microbiology of food and animal feeding stuffs - Horizontal methods for the detection and enumeration of Enterobacteriaceae - Part 2: Colony-count method. International Organization for Standardization, Geneva, Switzerland.

- Jevsnik, M., Hlebec, V. et al. 2008. Consumers' awareness of food safety from shopping to eating. Food Control 19: 737-745.

- Jimenez, M., Martinez-Urtaza, J. et al. 2011. Geographical and temporal dissemination of salmonellae isolated from domestic animal hosts in the Culiacan Valley, Mexico. Microbial Ecology 61(4): 811-820.

- Josephson, K. L., Rubino, J. R. et al. 1997. Characterization and quantification of bacterial pathogens and indicator organisms in household kitchens with and without the use of a disinfectant cleaner. Journal of Applied Microbiology 83(6): 737-750.

- Kelch, W. J. and Lee, J. S.. 1978. Antibiotic resistance patterns of gram-negative bacteria isolated from environmental sources. Applied and Environmental Microbiology36(3): 450-456.

- Kijima-Tanaka, M., Ishihara, K. et al. 2003. A national surveillance of antimicrobial resistance in Escherichia coli isolated from food-producing animals in Japan. Journal of Antimicrobial Chemotherapy 51(2): 447-451.

- Kloos, W. E. and Schleifer, K. H. 1986. Genus IV. Staphylococcus. Bergey's Manual of Systematic Bacteriology, Williams and Wilkins, Baltimore.

- Knezevic, P. and Petrovic, O. 2008. Antibiotic resistance of commensal Escherichia coli of foodproducing animals from three Vojvodinian farms, Serbia. International Journal of Antimicrobial Agents 31(4): 360-363.

- Kusumaningrum, H. D., Riboldi, G. et al. 2003. Survival of foodborne pathogens on stainless steel surfaces and cross-contamination to foods. International Journal of Food Microbiology 85(3): 227-236.

- Larson, E. L. 1999. Home hygiene: a reemerging issue for the new millennium. American Journal of Infection Control 27(6): S1-2.

- Leistevuo, T., Leistevuo, J. et al. 1996. Antimicrobial resistance of fecal aerobic gram-negative bacilli in different age groups in a community. Antimicrobial Agents and Chemotherapy 40(8): 1931-1934.

- Lester, S. C., del Pilar Pla, M. et al. 1990. The carriage of Escherichia coli resistant to antimicrobial agents by healthy children in Boston, in Caracas, Venezuela, and in Qin Pu, China. New England Journal of Medicine 323(5): 285-289.

- Levy, S. B., Marshall, B. et al. 1988. High frequency of antimicrobial resistance in human fecal flora. Antimicrobial Agents and Chemotherapy 32(12): 1801-1806. 
- Levy, S. B. 1998. The challenge of antibiotic resistance. Scientific American 278(3): 46-53.

- Levy, S. B. 2005. Antibiotic resistance-the problem intensifies. Advanced Drug Delivery Reviews 57(10): 1446-1450.

- Lundin, J. I., Dargatz, D. A. et al. 2008. Antimicrobial drug resistance of fecal Escherichia coli and Salmonella spp. isolates from United States dairy cows. Foodborne Pathogens and Disease 5(1): 7-19.

- Mafu, A. A., Roy, D. et al. 1990. Attachment of Listeria monocytogenes to stainless steel, glass, propylene and rubber after short contact times. Journal of Food Protection 53: 742-746.

- Mayrhofer, S., Paulsen, P. et al. 2004. Antimicrobial resistance profile of five major food-borne pathogens isolated from beef, pork and poultry. International Journal of Food Microbiology 97(1): 2329.

- Miranda, J. M., Guarddon, M. et al. 2008. Antimicrobial resistance in Enterobacteriaceae strains isolated from organic chicken, conventional chicken and conventional turkey meat: A comparative survey. Food Control 19: 412-416.

- Morrison, S. M., Fair, J. F. et al. 1961. Staphylococcus aureus in domestic animals. Public Health Reports 76: 673-677.

- Noronha, F., Silva, S. A., Mena, C., Almeida, G., Hogg, T., Gibbs, P., et al. 2006. Food Safety in the Domestic Environment: Kitchen Hygiene. Journal of Food Technology 4(4): 264-267.

- Notermans, S., Gallhoff, G. et al. 1995. Identification of critical control points in the HACCP system with a quantitative effect on the safety of food products. Food Microbiology 12(93-98).

- Oppegaard, H., Steinum, T. M. et al. 2001. Horizontal transfer of a multi-drug resistance plasmid between coliform bacteria of human and bovine origin in a farm environment. Applied and Environmental Microbiology 67(8): 3732-3734.

- Osterblad, M., Pensala, O. et al. 1999. Antimicrobial susceptibility of Enterobacteriaceae isolated from vegetables. Journal of Antimicrobial Chemotherapy 43(4): 503-509.

- Oswald, W. E., Lescano, A. G. et al. 2007. Fecal Contamination of Drinking Water within Peri-Urban Households, Lima, Peru. American Journal of Tropical Medicine and Hygiene 77(4): 699-704.

- Paterson, D. L. 2006. Resistance in gram-negative bacteria: Enterobacteriaceae. American Journal of Infection Control 34(5 Suppl 1): S20-28; discussion S64-73.

- Pfau, C. and Piekarski, J. 2003. Consumers' competence in handling food. Journal of Food Engineering 56 (2-3): 295-297.

- Piddock, L. J. 1999. Mechanisms of fluoroquinolone resistance: an update 1994-1998. Drugs 58 (Suppl 2): $11-18$.

- Pinto, A. 2007. Doenças de origem microbiana transmitidas pelos alimentos. Available: http://www.ipv.pt/millenium/ect4 1.htm (date visited: 04/06/2009).

- Prescott, L. M., Harley, J. P., Klein, D. A. 1999. Microbiology, Fourth Edition. MacGraw-Hill. pp. 963.

- Rampling, A., Upson, R. et al. 1990. Nitrofurantoin resistance in isolates of Salmonella enteritidis phage type 4 from poultry and humans. Journal of Antimicrobial Chemotherapy 25(2): 285-290. 
- Redmond, E. C. and Griffith, C. J. 2003. Consumer food handling in the home: a review of food safety studies. Journal of Food Protection 66(1): 130-161.

- Rheinbaben, F. V. et al. 2000. Transmission of viruses via contact in a household setting: Experiments using bacteriophage fX174 as a model virus. Journal of Hospital Infection 46: 1-66.

- Rhomberg, P. R., Fritsche, T. R. et al. 2006. Clonal occurrences of multidrug-resistant Gram-negative bacilli: report from the Meropenem Yearly Susceptibility Test Information Collection Surveillance Program in the United States (2004). Diagnostic Microbiology and Infectious Disease 54(4): 249-257.

- Ronald, A. 2002. The etiology of urinary tract infection: traditional and emerging pathogens. American Journal of Medicine 113 Suppl 1A: 14S-19S.

- Rusin, P., Orosz-Coughlin, P. et al. 1998. Reduction of faecal coliform, coliform and heterotrophic plate count bacteria in the household kitchen and bathroom by disinfection with hypochlorite cleaners. Journal of Applied Microbiology 85(5): 819-828.

- Ryan, M. J., Wall, P. G. et al. 1996. Risk factors for outbreaks of infectious intestinal disease linked to domestic catering. Communicable Disease Report. CDR Review 6(13): R179-183.

- Sáenz, Y., Zarazaga, M. et al. 2001. Antibiotic resistance in Escherichia coli isolates obtained from animals, foods and humans in Spain. International Journal of Antimicrobial Agents 18(4): 353-358.

- Sanborn, W. R. 1963. The Relation of Surface Contamination to the Transmission of Disease. American Journal of Public Health and the Nation's Health 53: 1278-1283.

- Schwaiger, K., Huther, S. et al. 2012. Prevalence of antibiotic-resistant Enterobacteriaceae isolated from chicken and pork meat purchased at the slaughterhouse and at retail in Bavaria, Germany. International Journal of Food Microbiology 154(3): 206-211.

- Scott, E., Bloomfield, S. F. et al. 1982. An investigation of microbial contamination in the home. Journal of Hygiene 89(2): 279-293.

- Scott, E. and Bloomfield, S. F. 1990. The survival and transfer of microbial contamination via cloths, hands and utensils. Journal of Applied Bacteriology 68(3): 271-278.

- Scott, E. 1996. Foodborne disease and other hygiene issues in the home. Journal of Applied Bacteriology 80(1): 5-9.

- Scott, E. 1999. Hygiene issues in the home. American Journal of Infection Control 27(6): S22-25.

- Scott, E. 2001. Developing a rational approach to hygiene in the domestic setting. Journal of Infection 43(1): 45-49.

- Scott, E. 2003. Food safety and foodborne disease in $21^{\text {st }}$ century homes. The Canadian Journal of Infectious Diseases 14(5): 277-280.

- Schroeder, C. M., Meng, J. et al. 2002. Antimicrobial resistance of Escherichia coli O26, O103, O111, O128, and O145 from animals and humans. Emerging Infection Diseases 8(12): 1409-1414.

- Schroeder, C. M., White, D. G. et al. 2003. Isolation of antimicrobial-resistant Escherichia coli from retail meats purchased in Greater Washington, DC, USA. International Journal of Food Microbiology 85(1-2): 197-202. 
- Schwaiger, K., Huther, S. et al. 2012. Prevalence of antibiotic-resistant enterobacteriaceae isolated from chicken and pork meat purchased at the slaughterhouse and at retail in Bavaria, Germany. International Journal of Food Microbiology 154(3): 206-211.

- Sefton, A. M. 2000. The impact of resistance on the management of urinary tract infections. International Journal of Antimicrobial Agents 16(4): 489-491.

- Shannon, K. P. and French, G. L. 2004. Increasing resistance to antimicrobial agents of Gram-negative organisms isolated at a London teaching hospital, 1995-2000. Journal of Antimicrobial Chemotherapy 53(5): 818-825.

- Speirs, J. P., Anderton, A. et al. 1995. A study of the microbial content of the domestic kitchen. International Journal of Environmental Health Research 5: 109-122.

- Su, H. C., Ying, G. G. et al. 2011. Occurrence of antibiotic resistance and characterization of resistance genes and integrons in Enterobacteriaceae isolated from integrated fish farms in South China. Journal of Environmental Monitoring 13(11): 3229-3236.

- Tao, R., Ying, G. G. et al. 2010. Detection of antibiotic resistance and tetracycline resistance genes in Enterobacteriaceae isolated from the Pearl rivers in South China. Environmental Pollution 158(6): 2101-2109.

- Threlfall, E. J. 2002. Antimicrobial drug resistance in Salmonella: problems and perspectives in foodand water-borne infections. FEMS Microbiology Reviews 26(2): 141-148.

- van den Bogaard, A. E. and Stobberingh, E. E.. 2000. Epidemiology of resistance to antibiotics. Links between animals and humans. International Journal of Antimicrobial Agents 14(4): 327-335.

- van den Bogaard, A. E., London, N. et al. 2000. Antimicrobial resistance in pig faecal samples from the Netherlands (five abattoirs) and Sweden. Journal of Antimicrobial Chemotherapy 45(5): 663-671.

- van den Bogaard, A. E., London, N. et al. 2001. Antibiotic resistance of faecal Escherichia coli in poultry, poultry farmers and poultry slaughterers. Journal of Antimicrobial Chemotherapy 47(6): 763771.

- Warren, J. W., Abrutyn, E. et al. 1999. Guidelines for antimicrobial treatment of uncomplicated acute bacterial cystitis and acute pyelonephritis in women. Infectious Diseases Society of America (IDSA). Clinical Infection Diseases 29(4): 745-758.

- Weis, J. and Seeliger, H. P. 1975. Incidence of Listeria monocytogenes in nature. Applied Microbiology 30(1): 29-32.

- Westwood. J. C. N., Mitchell, M. A. et al. 1971. Legace S. Hospital sanitation: the massive bacterial contamination of the wet mop. Applied Microbiology 21: 693-695.

- WHA. 2010. Advancing food safety initiatives. Sixty-third World Health Assembly (WHA 63.3) Agenda item 11.8.

- WHO. 2002. WHO global strategy for food safety : safer food for better health. Geneva: WHO.

- WHO. 2004. Surveillance Programme for Control of Foodborne Infections and Toxications in Europe 8th report 1999-2000, Country reports: Turkey. 
- WHO. 2007. Environment Burden of Disease Series, № 15 - Water, sanitation and hygiene links to health. Public Health and the Environment. Geneva: WHO

- WHO. 2007. Food Safety and Foodborne Illness. Fact Sheet no237, Reviewed March 2007.

- Wilcock, A., Pun, M. et al. 2004. Consumer attitudes, knowledge and behaviour: a review of food safety issues. Trends in Food Science \& Technology 15: 56-66.

- Wu, P. J., Shannon, K. et al. 1992. Beta-Lactamases and susceptibility to beta-lactam antibiotics in Escherichia coli. Journal of Antimicrobial Chemotherapy 30(6): 868-871.

- Zhao, P., Zhao, T. et al. 1998. Development of a model for evaluation of microbial cross-contamination in the kitchen. Journal of Food Protection 61(8): 960-963. 


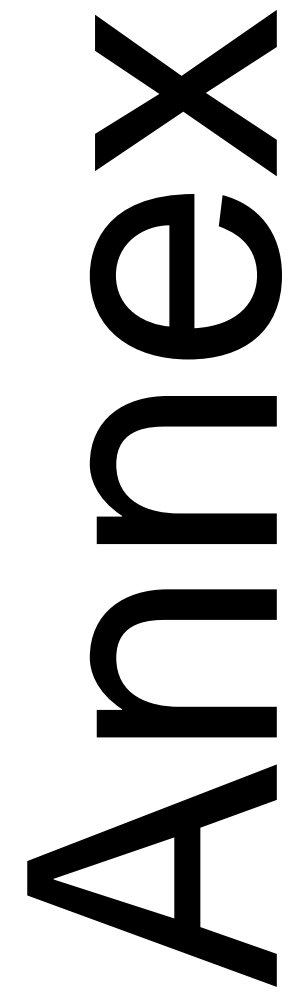




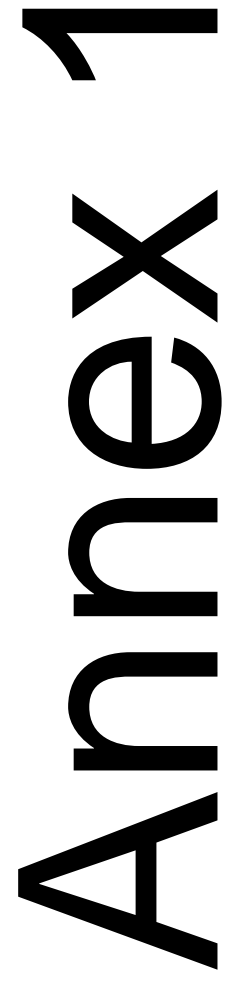




\section{MIC's Breakpoints}

MICa $(\mu \mathrm{g} / \mathrm{mL})$ Breakpoints

\begin{tabular}{|c|c|c|c|c|}
\hline \multirow[b]{2}{*}{ Class } & \multirow[b]{2}{*}{ Antibiotic } & \\
\hline & & $\begin{array}{c}\text { S } \\
\text { (Sensitive) }\end{array}$ & $\begin{array}{c}\text { I } \\
\text { (Intermediary) }\end{array}$ & $\begin{array}{c}\mathbf{R} \\
\text { (Resistant) }\end{array}$ \\
\hline Penicillins & Ampicillin (AMP) & $\leq 8$ & 16 & $\geq 32$ \\
\hline Phenicols & Chloramphenicol (CHL) & $\leq 8$ & 16 & $\geq 32$ \\
\hline Fluoroquinolones & Ciprofloxacin (CIP) & $\leq 1$ & 2 & $\geq 4$ \\
\hline Aminoglycosides & Gentamicin (GEN) & $\leq 4$ & 8 & $\geq 16$ \\
\hline Quinolones & Nalidixic acid (NAL) & $\leq 16$ & --- & $\geq 32$ \\
\hline Tetracyclines & Tetracycline (TET) & $\leq 4$ & 8 & $\geq 16$ \\
\hline $\begin{array}{l}\text { Folate pathway } \\
\text { inhibitors }\end{array}$ & Trimethoprim (TMP) & $\leq 8$ & --- & $\geq 16$ \\
\hline Nitrofurantoins & Nitrofurantoin (NIT) & $\leq 32$ & 64 & $\geq 128$ \\
\hline
\end{tabular}

a - Classification according to the guidelines of NCCLS (2004).

HOUSE 1

\begin{tabular}{|c|c|c|c|c|c|c|c|c|c|}
\hline \multirow{2}{*}{ Local } & \multirow{2}{*}{ Microorganism } & \multicolumn{8}{|c|}{ Antibiotic MIC's $(\mu \mathrm{g} / \mathrm{mL})$ Breakpoints } \\
\hline & & AMP & $\mathrm{CHL}$ & CIP & GEN & NAL & TET & TMP & NIT \\
\hline \multirow{2}{*}{$\begin{array}{c}\text { Domestic Animal } \\
\text { (Dog) }\end{array}$} & \multirow{2}{*}{ Enterobacteriaceae spp. } & $8(\mathbf{S})$ & $2(\mathbf{S})$ & $0,03(\mathbf{S})$ & $0,5(\mathbf{S})$ & $4(\mathbf{S})$ & $1(\mathbf{S})$ & $0,25(\mathbf{S})$ & $64(\mathrm{I})$ \\
\hline & & $2(\mathbf{S})$ & $2(\mathbf{S})$ & $0,03(\mathbf{S})$ & $1(\mathbf{S})$ & $4(S)$ & $1(\mathbf{S})$ & $0,25(\mathbf{S})$ & 64 (I) \\
\hline \multirow{2}{*}{$\begin{array}{c}\text { Domestic Animal } \\
\text { (Dog) }\end{array}$} & \multirow{2}{*}{ Enterobacteriaceae spp. } & $4(\mathbf{S})$ & $2(\mathbf{S})$ & $<0,015(\mathbf{S})$ & $0,5(\mathbf{S})$ & $2(\mathbf{S})$ & $0,5(\mathbf{S})$ & $0,125(\mathbf{S})$ & $64(\mathrm{I})$ \\
\hline & & $16(\mathbf{I})$ & $4(\mathbf{S})$ & $0,06(\mathbf{S})$ & $1(\mathbf{S})$ & $8(\mathbf{S})$ & $0,5(\mathbf{S})$ & $>128(\mathbf{R})$ & $32(\mathbf{S})$ \\
\hline \multirow{2}{*}{ Domestic Animal (Cat) } & \multirow{2}{*}{ Enterobacteriaceae spp. } & $1(\mathbf{S})$ & $2(\mathbf{S})$ & $<0,015(\mathbf{S})$ & $1(\mathrm{~S})$ & $4(\mathbf{S})$ & $2(\mathbf{S})$ & $0,5(\mathbf{S})$ & $32(\mathbf{S})$ \\
\hline & & $1(\mathbf{S})$ & $2(\mathbf{S})$ & $<0,015(\mathbf{S})$ & $1(\mathbf{S})$ & $4(S)$ & $2(\mathbf{S})$ & $0,5(\mathbf{S})$ & $32(\mathbf{S})$ \\
\hline \multirow{2}{*}{ Domestic Animal (Cat) } & \multirow{2}{*}{ Salmonella spp. } & $4(\mathrm{~S})$ & $8(\mathbf{S})$ & $0,03(\mathbf{S})$ & $1(\mathbf{S})$ & $2(\mathbf{S})$ & $8(\mathrm{I})$ & $4(\mathrm{~S})$ & $64(\mathrm{I})$ \\
\hline & & $4(\mathrm{~S})$ & $8(\mathbf{S})$ & 0,03 (S) & $0,5(\mathbf{S})$ & $2(\mathbf{S})$ & 8 (I) & $4(\mathrm{~S})$ & $128(\mathbf{R})$ \\
\hline \multirow{2}{*}{ Cutting Board } & \multirow{2}{*}{ Enterobacteriaceae spp. } & $64(\mathbf{R})$ & $8(\mathbf{S})$ & $0,06(\mathbf{S})$ & $1(\mathbf{S})$ & $8(\mathbf{S})$ & $4(\mathrm{~S})$ & $4(\mathrm{~S})$ & $64(\mathrm{I})$ \\
\hline & & $64(\mathbf{R})$ & $8(\mathbf{S})$ & $0,06(\mathbf{S})$ & $2(\mathbf{s})$ & $8(\mathbf{S})$ & $4(\mathrm{~S})$ & $8(\mathbf{S})$ & 64 (I) \\
\hline \multirow{2}{*}{ Kitchen Counter } & \multirow{2}{*}{ Enterobacteriaceae spp. } & $32(\mathbf{R})$ & $4(\mathrm{~S})$ & $0,03(\mathbf{S})$ & $2(\mathbf{S})$ & $4(\mathrm{~S})$ & $4(\mathrm{~S})$ & $1(\mathbf{S})$ & $16(\mathbf{S})$ \\
\hline & & $32(\mathbf{R})$ & $8(\mathbf{S})$ & $0,06(\mathbf{S})$ & $1(\mathrm{~S})$ & $8(\mathbf{S})$ & $4(\mathrm{~S})$ & $8(\mathbf{S})$ & $64(\mathbf{I})$ \\
\hline Kitchen Cloth & Enterobacteriaceae spp. & $8(\mathbf{S})$ & $8(\mathbf{S})$ & $0,03(\mathbf{S})$ & $1(\mathbf{S})$ & $4(S)$ & $2(\mathbf{S})$ & $1(\mathbf{S})$ & $32(\mathbf{S})$ \\
\hline
\end{tabular}

HOUSE 2

\begin{tabular}{|c|c|c|c|c|c|c|c|c|c|}
\hline \multirow{2}{*}{ Local } & \multirow{2}{*}{ Microorganism } & \multicolumn{8}{|c|}{ Antibiotic MIC's $(\mu \mathrm{g} / \mathrm{mL})$ Breakpoints } \\
\hline & & AMP & CHL & CIP & GEN & NAL & TET & TMP & NIT \\
\hline & & $16(\mathbf{I})$ & $4(\mathrm{~S})$ & $0,03(\mathbf{S})$ & $1(\mathbf{S})$ & $8(\mathbf{S})$ & $1(\mathbf{S})$ & $1(\mathbf{S})$ & $32(\mathbf{S})$ \\
\hline Kitchen Iap & Salmonella spp. & $4(\mathrm{~S})$ & $8(\mathbf{S})$ & $0,03(\mathbf{S})$ & $1(\mathbf{S})$ & $8(\mathbf{S})$ & $2(\mathbf{S})$ & $1(\mathbf{S})$ & $32(\mathbf{S})$ \\
\hline Kitchen Cloth & Salmonella spp. & $\begin{array}{c}256(\mathrm{R}) \\
4(\mathrm{~S})\end{array}$ & $\begin{array}{l}8(\mathbf{S}) \\
16(\mathbf{I})\end{array}$ & $\begin{array}{c}0,125(\mathbf{S}) \\
<0,015(\mathbf{S})\end{array}$ & $\begin{array}{l}1(\mathbf{S}) \\
1(\mathbf{S})\end{array}$ & $\begin{array}{l}8(\mathbf{S}) \\
8(\mathbf{S})\end{array}$ & $\begin{array}{l}8(\mathrm{I}) \\
2(\mathrm{~S})\end{array}$ & $\begin{array}{l}2(\mathbf{S}) \\
1(\mathbf{S})\end{array}$ & $\begin{array}{l}32(\mathbf{S}) \\
32(\mathbf{S})\end{array}$ \\
\hline
\end{tabular}


HOUSE 3

\begin{tabular}{|c|c|c|c|c|c|c|c|c|c|}
\hline \multirow{2}{*}{ Local } & \multirow{2}{*}{ Microorganism } & \multicolumn{8}{|c|}{ Antibiotic MIC's $(\mu \mathrm{g} / \mathrm{mL})$ Breakpoints } \\
\hline & & AMP & CHL & CIP & GEN & NAL & TET & TMP & NIT \\
\hline \multirow{2}{*}{$\begin{array}{l}\text { Domestic Animal } \\
\text { (Dog) }\end{array}$} & \multirow{2}{*}{ Salmonella spp. } & $8(\mathbf{S})$ & $8(\mathbf{S})$ & $<0,015(\mathbf{S})$ & $1(\mathbf{S})$ & $8(\mathbf{S})$ & $4(\mathbf{S})$ & $0,5(\mathbf{S})$ & $32(\mathbf{S})$ \\
\hline & & $8(\mathbf{S})$ & $8(\mathbf{S})$ & $<0,015(\mathbf{S})$ & $1(\mathbf{S})$ & $8(\mathbf{S})$ & $4(S)$ & $0,5(\mathbf{S})$ & $16(\mathbf{S})$ \\
\hline \multirow{2}{*}{ WC Knob } & \multirow{2}{*}{ Salmonella spp. } & $8(\mathbf{S})$ & $8(\mathbf{S})$ & $0,03(\mathbf{S})$ & $1(\mathbf{S})$ & $8(\mathbf{S})$ & $4(\mathbf{S})$ & $0,5(\mathbf{S})$ & $16(\mathbf{S})$ \\
\hline & & $8(\mathbf{S})$ & $8(\mathbf{S})$ & $<0,015$ (S) & $1(\mathbf{S})$ & $4(\mathrm{~S})$ & $2(\mathbf{S})$ & $0,5(\mathbf{S})$ & $16(\mathbf{S})$ \\
\hline \multirow{2}{*}{ Kitchen Tap } & \multirow{2}{*}{ Enterobacteriaceae spp. } & $8(\mathbf{S})$ & $8(\mathbf{S})$ & $0,03(\mathbf{S})$ & $0,5(\mathbf{S})$ & $8(\mathbf{S})$ & $2(\mathbf{S})$ & $0,25(\mathbf{S})$ & $16(\mathbf{S})$ \\
\hline & & $8(\mathbf{S})$ & $8(\mathbf{S})$ & $0,03(\mathbf{S})$ & $1(\mathbf{S})$ & $4(\mathrm{~S})$ & $8(\mathrm{I})$ & $1(\mathbf{S})$ & $64(\mathbf{R})$ \\
\hline \multirow{2}{*}{ Kitchen Counter } & \multirow{2}{*}{ Salmonella spp. } & $16(\mathrm{I})$ & $8(\mathbf{S})$ & $0,03(\mathbf{S})$ & $0,5(\mathbf{S})$ & $4(\mathrm{~S})$ & $2(\mathbf{S})$ & $0,5(\mathbf{S})$ & $16(\mathbf{S})$ \\
\hline & & 16 (I) & $8(\mathbf{S})$ & $0,03(\mathbf{S})$ & $0,5(\mathbf{S})$ & $4(\mathrm{~S})$ & $4(\mathrm{~S})$ & $0,25(\mathbf{S})$ & $32(\mathbf{S})$ \\
\hline \multirow{2}{*}{ Cutting Board } & \multirow{2}{*}{ Salmonella spp. } & $64(\mathrm{R})$ & $16(\mathrm{I})$ & $0,25(\mathbf{S})$ & $2(\mathbf{S})$ & $4(\mathbf{S})$ & $128(\mathbf{R})$ & $2(\mathbf{S})$ & $128(\mathrm{R})$ \\
\hline & & 64 (R) & $32(\mathbf{R})$ & $0,5(\mathbf{S})$ & $2(\mathbf{S})$ & $4(\mathrm{~S})$ & $128(\mathbf{R})$ & $2(\mathbf{S})$ & $128(\mathbf{R})$ \\
\hline \multirow{2}{*}{ Kitchen Cloth } & \multirow{2}{*}{ Escherichia coli } & $32(\mathbf{R})$ & $8(\mathbf{S})$ & $0,125(\mathbf{S})$ & $0,5(\mathbf{S})$ & $4(\mathrm{~S})$ & $2(\mathbf{S})$ & $1(\mathbf{S})$ & $16(\mathbf{S})$ \\
\hline & & $32(\mathbf{R})$ & $4(\mathrm{~S})$ & $0,03(\mathbf{S})$ & $0,5(\mathbf{S})$ & $4(\mathbf{S})$ & $2(\mathbf{S})$ & $1(\mathbf{S})$ & $16(\mathbf{S})$ \\
\hline
\end{tabular}

\section{HOUSE 4}

\begin{tabular}{|c|c|c|c|c|c|c|c|c|c|}
\hline \multirow{2}{*}{ Local } & \multirow{2}{*}{ Microorganism } & \multicolumn{8}{|c|}{ Antibiotic MIC's $(\mu \mathrm{g} / \mathrm{mL})$ Breakpoints } \\
\hline & & AMP & $\mathbf{C H L}$ & CIP & GEN & NAL & TET & TMP & NIT \\
\hline Kitchen Tan & Salmonella spp. & $32(\mathbf{R})$ & $8(\mathbf{S})$ & $0,03(\mathbf{S})$ & $1(\mathbf{S})$ & $4(\mathbf{S})$ & $8(\mathrm{I})$ & $4(\mathbf{S})$ & $64(\mathrm{I})$ \\
\hline KItchen I ap & Enterobacteriaceae spp. & $16(\mathbf{I})$ & $4(S)$ & $0,03(\mathbf{S})$ & $0,5(\mathbf{S})$ & $4(S)$ & $2(\mathbf{S})$ & $0,5(\mathbf{S})$ & 64 (I) \\
\hline Kitchen Counter & Enterobacteriaceae spp. & $8(\mathbf{S})$ & $2(\mathbf{S})$ & $0,03(\mathbf{S})$ & $1(\mathbf{S})$ & $4(\mathbf{S})$ & $2(\mathbf{S})$ & $0,25(\mathbf{S})$ & $16(\mathbf{S})$ \\
\hline KItchen counter & Escherichia coli & $256(\mathbf{R})$ & $8(\mathbf{S})$ & $0,03(\mathbf{S})$ & $1(\mathbf{S})$ & $8(\mathbf{S})$ & $4(S)$ & $1(\mathbf{S})$ & $128(\mathrm{R})$ \\
\hline Refrigerator Handle & Escherichia coli & $4(\mathrm{~S})$ & $8(\mathbf{S})$ & $0,03(\mathbf{S})$ & $0,5(\mathbf{S})$ & $2(\mathbf{S})$ & $8(\mathrm{I})$ & $8(\mathbf{S})$ & $64(\mathrm{I})$ \\
\hline Dishwasher Handle & Enterobacteriaceae spp. & $16(\mathrm{I})$ & $8(\mathbf{S})$ & $0,03(\mathbf{S})$ & $0,5(\mathbf{S})$ & $4(\mathrm{~S})$ & $8(\mathrm{I})$ & $0,5(\mathbf{S})$ & $128(\mathbf{R})$ \\
\hline
\end{tabular}

\section{HOUSE 5}

\begin{tabular}{|c|c|c|c|c|c|c|c|c|c|}
\hline \multirow{2}{*}{ Local } & \multirow{2}{*}{ Microorganism } & \multicolumn{8}{|c|}{ Antibiotic MIC's $(\mu \mathrm{g} / \mathrm{mL})$ Breakpoints } \\
\hline & & AMP & $\mathbf{C H L}$ & CIP & GEN & NAL & TET & TMP & NIT \\
\hline \multirow{2}{*}{ WC Knob } & \multirow{2}{*}{ Enterobacteriaceae spp. } & $4(\mathbf{S})$ & $4(\mathbf{S})$ & $<0,015(\mathbf{S})$ & $0,25(\mathbf{S})$ & $2(\mathbf{S})$ & $2(\mathbf{S})$ & $0,125(\mathbf{S})$ & $64(\mathrm{I})$ \\
\hline & & $4(\mathbf{S})$ & $4(\mathbf{S})$ & $<0,015(\mathbf{S})$ & $0,25(\mathbf{S})$ & $2(\mathbf{S})$ & $2(\mathbf{S})$ & $0,125(\mathbf{S})$ & 64 (I) \\
\hline Kitchen Counter & Escherichia coli & $4(\mathbf{S})$ & $4(\mathrm{~S})$ & $0,03(\mathbf{S})$ & $0,5(\mathbf{S})$ & $2(\mathbf{S})$ & $2(\mathbf{S})$ & $0,25(\mathbf{S})$ & $64(\mathbf{I})$ \\
\hline \multirow{2}{*}{ Dishwasher Handle } & \multirow{2}{*}{ Escherichia coli } & $0,5(\mathbf{S})$ & $1(\mathbf{S})$ & $<0,015(\mathbf{S})$ & $0,5(\mathbf{S})$ & $2(\mathbf{S})$ & $0,5(\mathbf{S})$ & $0,25(\mathbf{S})$ & $32(\mathbf{S})$ \\
\hline & & $0,5(\mathbf{S})$ & $1(\mathbf{S})$ & $<0,015$ (S) & $0,5(\mathbf{S})$ & $4(S)$ & $0,5(\mathbf{S})$ & $0,5(\mathbf{S})$ & $16(\mathbf{S}$ \\
\hline \multirow{2}{*}{ Kitchen Cloth } & Escherichia coli & $16(\mathrm{I})$ & $4(S)$ & $<0,015(\mathbf{S})$ & $0,5(\mathbf{S})$ & $2(\mathbf{S})$ & $0,5(\mathbf{S})$ & $0,25(\mathbf{S})$ & $32(\mathbf{S}$ \\
\hline & Enterobacteriaceae spp. & $8(\mathbf{S})$ & $4(\mathrm{~S})$ & $<0,015(\mathbf{S})$ & $0,25(\mathbf{S})$ & $2(\mathbf{S})$ & $0,5(\mathbf{S})$ & $0,25(\mathbf{S})$ & $32(\mathbf{S}$ \\
\hline
\end{tabular}


HOUSE 6

\begin{tabular}{|c|c|c|c|c|c|c|c|c|c|}
\hline \multirow{2}{*}{ Local } & \multirow{2}{*}{ Microorganism } & \multicolumn{8}{|c|}{ Antibiotic MIC's $(\mu \mathrm{g} / \mathrm{mL})$ Breakpoints } \\
\hline & & AMP & CHL & CIP & GEN & NAL & TET & TMP & NIT \\
\hline $\begin{array}{c}\text { Domestic Animal } \\
\text { (Cat) }\end{array}$ & Enterobacteriaceae spp. & $\begin{array}{l}32(\mathbf{R}) \\
32(\mathbf{R})\end{array}$ & $\begin{array}{l}8(\mathbf{S}) \\
16(\mathbf{I})\end{array}$ & $\begin{array}{l}0,06(\mathbf{S}) \\
0,03(\mathbf{S})\end{array}$ & $\begin{array}{l}1(\mathbf{S}) \\
1(\mathbf{S})\end{array}$ & $\begin{array}{l}4(\mathbf{S}) \\
4(\mathbf{S})\end{array}$ & $\begin{array}{l}2(\mathbf{S}) \\
2(\mathbf{S})\end{array}$ & $\begin{array}{l}0,5(\mathbf{S}) \\
0,5(\mathbf{S})\end{array}$ & $\begin{array}{l}64(\mathrm{I}) \\
64(\mathrm{I})\end{array}$ \\
\hline Kitchen Tap & Enterobacteriaceae spp. & $\begin{array}{l}16(\mathbf{I}) \\
8(\mathbf{S})\end{array}$ & $\begin{array}{l}2(\mathbf{S}) \\
2(\mathbf{S})\end{array}$ & $\begin{array}{c}<0,015(\mathbf{S}) \\
0,03(\mathbf{S})\end{array}$ & $\begin{array}{c}1(\mathbf{S}) \\
0,5(\mathbf{S})\end{array}$ & $\begin{array}{l}2(\mathbf{S}) \\
2(\mathbf{S})\end{array}$ & $\begin{array}{c}1(\mathbf{S}) \\
0,5(\mathbf{S})\end{array}$ & $\begin{array}{c}0,5(\mathbf{S}) \\
0,25(\mathbf{S})\end{array}$ & $\begin{array}{r}8(\mathbf{S}) \\
32(\mathbf{S}\end{array}$ \\
\hline
\end{tabular}

\section{HOUSE 7}

\begin{tabular}{|c|c|c|c|c|c|c|c|c|c|}
\hline \multirow{2}{*}{ Local } & \multirow{2}{*}{ Microorganism } & \multicolumn{8}{|c|}{ Antibiotic MIC's ( $\mu \mathrm{g} / \mathrm{mL})$ Breakpoints } \\
\hline & & AMP & $\mathrm{CHL}$ & CIP & GEN & NAL & TET & TMP & NIT \\
\hline \multirow{2}{*}{ Kitchen Tap } & \multirow{2}{*}{ Escherichia coli } & $64(\mathbf{R})$ & $4(\mathbf{S})$ & $<0,015(\mathbf{S})$ & $1(\mathbf{S})$ & $4(\mathbf{S})$ & $2(\mathbf{S})$ & $1(\mathbf{S})$ & $16(\mathbf{S})$ \\
\hline & & $16(\mathbf{I})$ & $4(\mathrm{~S})$ & $<0,015(\mathbf{S})$ & $1(\mathbf{S})$ & $4(\mathbf{S})$ & $1(\mathbf{S})$ & $0,5(\mathbf{S})$ & $16(\mathbf{S})$ \\
\hline \multirow{2}{*}{ Refrigerator Handle } & Escherichia coli & $128(\mathbf{R})$ & $4(\mathbf{S})$ & $0,03(\mathbf{S})$ & $0,5(\mathbf{S})$ & $4(\mathbf{S})$ & $4(\mathrm{~S})$ & $1(\mathbf{S})$ & $16(\mathbf{S})$ \\
\hline & Salmonella spp. & $16(\mathbf{I})$ & $8(\mathbf{S})$ & $0,03(\mathbf{S})$ & $1(\mathbf{S})$ & $4(\mathrm{~S})$ & $4(S)$ & $2(\mathbf{S})$ & 64 (I) \\
\hline \multirow{2}{*}{ Dishwasher Handle } & Salmonella spp. & $8(\mathbf{S})$ & $2(\mathbf{S})$ & $<0,015(\mathbf{S})$ & $0,5(\mathbf{S})$ & $1(\mathbf{S})$ & $1(\mathbf{S})$ & $0,5(\mathbf{S})$ & $32(\mathbf{S})$ \\
\hline & Enterobacteriaceae spp. & $4(\mathrm{~S})$ & $8(\mathbf{S})$ & $0,03(\mathbf{S})$ & $1(\mathbf{S})$ & $2(\mathrm{~S})$ & $2(\mathrm{~S})$ & $0,25(\mathbf{S})$ & $32(\mathbf{S})$ \\
\hline \multirow{2}{*}{ Kitchen Cloth } & \multirow{2}{*}{ Enterobacteriaceae spp. } & $4(\mathrm{~S})$ & $4(\mathbf{S})$ & $0,03(\mathbf{S})$ & $0,5(\mathbf{S})$ & $1(\mathbf{S})$ & $2(\mathbf{S})$ & $2(\mathbf{S})$ & $64(\mathrm{I})$ \\
\hline & & $4(\mathrm{~S})$ & $4(\mathrm{~S})$ & $0,03(\mathbf{S})$ & $0,5(\mathbf{S})$ & $0,5(\mathbf{S})$ & $2(\mathbf{S})$ & $1(\mathbf{S})$ & 64 (I) \\
\hline
\end{tabular}

\section{HOUSE 8}

\begin{tabular}{|c|c|c|c|c|c|c|c|c|c|}
\hline \multirow{2}{*}{ Local } & \multirow{2}{*}{ Microorganism } & \multicolumn{8}{|c|}{ Antibiotic MIC's $(\mu \mathrm{g} / \mathrm{mL})$ Breakpoints } \\
\hline & & AMP & $\mathrm{CHL}$ & CIP & GEN & NAL & TET & TMP & NIT \\
\hline \multirow{2}{*}{ WC Knob } & \multirow{2}{*}{ Enterobacteriaceae spp. } & $2(\mathbf{S})$ & $4(\mathrm{~S})$ & $0,06(\mathbf{S})$ & $0,5(\mathbf{S})$ & $4(\mathbf{S})$ & $2(\mathbf{S})$ & $0,5(\mathbf{S})$ & $128(\mathrm{R})$ \\
\hline & & $2(\mathbf{S})$ & $8(\mathbf{S})$ & $0,06(\mathbf{S})$ & $0,5(\mathbf{S})$ & $4(\mathbf{S})$ & $2(\mathbf{S})$ & $2(\mathbf{S})$ & 64 (I) \\
\hline \multirow{2}{*}{ Kitchen Knob } & \multirow{2}{*}{ Enterobacteriaceae spp. } & $1(\mathbf{S})$ & $2(\mathbf{S})$ & $<0,015(\mathbf{S})$ & $0,5(\mathbf{S})$ & $2(\mathbf{S})$ & $0,5(\mathbf{S})$ & $0,5(\mathbf{S})$ & $32(\mathbf{S})$ \\
\hline & & $4(\mathbf{S})$ & $4(\mathrm{~S})$ & $0,03(\mathbf{S})$ & $0,5(\mathbf{S})$ & $4(\mathbf{S})$ & $2(\mathbf{S})$ & $0,5(\mathbf{S})$ & 32 (S) \\
\hline \multirow{2}{*}{ Cutting Board } & \multirow{2}{*}{ Escherichia coli } & $0,5(\mathbf{S})$ & $2(\mathbf{S})$ & $<0,015(\mathbf{S})$ & $0,5(\mathbf{S})$ & $2(\mathbf{S})$ & $0,5(\mathbf{S})$ & $0,5(\mathbf{S})$ & $32(\mathbf{S})$ \\
\hline & & $0,5(\mathbf{S})$ & $2(\mathbf{S})$ & $<0,015$ (S) & $0,5(\mathbf{S})$ & $2(\mathbf{S})$ & $0,5(\mathbf{S})$ & $0,5(\mathbf{S})$ & $32(\mathbf{S})$ \\
\hline \multirow{2}{*}{ Kitchen Cloth } & \multirow{2}{*}{ Escherichia coli } & $4(\mathrm{~S})$ & $4(\mathrm{~S})$ & $<0,015(\mathbf{S})$ & $0,5(\mathbf{S})$ & $4(\mathrm{~S})$ & $2(\mathbf{S})$ & $0,25(\mathbf{S})$ & $64(\mathrm{I})$ \\
\hline & & $4(\mathrm{~S})$ & $2(\mathbf{S})$ & $<0,015(\mathbf{S})$ & $0,5(\mathbf{S})$ & $2(\mathbf{S})$ & $0,5(\mathbf{S})$ & 0,25 (S) & $16(\mathbf{S})$ \\
\hline
\end{tabular}




\section{HOUSE 9}

\begin{tabular}{|c|c|c|c|c|c|c|c|c|c|}
\hline \multirow{2}{*}{ Local } & \multirow{2}{*}{ Microorganism } & \multicolumn{8}{|c|}{ Antibiotic MIC's $(\mu \mathrm{g} / \mathrm{mL})$ Breakpoints } \\
\hline & & AMP & $\overline{\mathrm{CHL}}$ & CIP & GEN & NAL & TET & TMP & NIT \\
\hline Kitchen Knob & Escherichia coli & $\begin{array}{l}32(\mathbf{R}) \\
32(\mathbf{R})\end{array}$ & $\begin{array}{l}2(\mathbf{S}) \\
2(\mathbf{S})\end{array}$ & $\begin{array}{l}0,03(\mathbf{S}) \\
0,03(\mathbf{S})\end{array}$ & $\begin{array}{c}1(\mathbf{S}) \\
0,5(\mathbf{S})\end{array}$ & $\begin{array}{l}2(\mathbf{S}) \\
2(\mathbf{S})\end{array}$ & $\begin{array}{l}1 \text { (S) } \\
1(\mathbf{S})\end{array}$ & $\begin{array}{l}0,25(\mathbf{S}) \\
0,25(\mathbf{S})\end{array}$ & $\begin{array}{l}32(\mathbf{S} \\
32(\mathbf{S}\end{array}$ \\
\hline Kitchen Counter & Enterobacteriaceae spp. & $\begin{array}{c}4(\mathbf{S}) \\
32(\mathbf{R})\end{array}$ & $\begin{array}{l}8(\mathbf{S}) \\
2(\mathbf{S})\end{array}$ & $\begin{array}{c}0,03(\mathbf{S}) \\
<0,015(\mathbf{S})\end{array}$ & $\begin{array}{l}0,5(\mathbf{S}) \\
0,5(\mathbf{S})\end{array}$ & $\begin{array}{l}1(\mathrm{~S}) \\
2(\mathrm{~S})\end{array}$ & $\begin{array}{c}4(\mathbf{S}) \\
0,5(\mathbf{S})\end{array}$ & $\begin{array}{c}2(\mathbf{S}) \\
0,25(\mathbf{S})\end{array}$ & $\begin{array}{l}64(\mathrm{I}) \\
16(\mathrm{~S})\end{array}$ \\
\hline Kitchen Cloth & Enterobacteriaceae spp. & $\begin{array}{l}4(\mathrm{~S}) \\
4(\mathrm{~S})\end{array}$ & $\begin{array}{l}8(\mathbf{S}) \\
8(\mathbf{S})\end{array}$ & $\begin{array}{l}0,03(\mathbf{S}) \\
0,03(\mathbf{S})\end{array}$ & $\begin{array}{l}0,5(\mathbf{S}) \\
0,5(\mathbf{S})\end{array}$ & $\begin{array}{l}1(\mathbf{S}) \\
1(\mathbf{S})\end{array}$ & $\begin{array}{l}4(\mathrm{~S}) \\
4(\mathbf{S})\end{array}$ & $\begin{array}{l}2(\mathbf{S}) \\
2(\mathbf{S})\end{array}$ & $\begin{array}{l}64(\mathrm{I}) \\
64(\mathrm{I})\end{array}$ \\
\hline
\end{tabular}

\section{HOUSE 10}

\begin{tabular}{|c|c|c|c|c|c|c|c|c|c|}
\hline \multirow{2}{*}{ Local } & \multirow{2}{*}{ Microorganism } & \multicolumn{8}{|c|}{ Antibiotic MIC's ( $\mu \mathrm{g} / \mathrm{mL})$ Breakpoints } \\
\hline & & AMP & CHL & CIP & GEN & NAL & TET & TMP & NIT \\
\hline \multirow{2}{*}{ WC Tap } & \multirow{2}{*}{ Escherichia coli } & $16(\mathrm{I})$ & $2(\mathbf{S})$ & $0,03(\mathbf{S})$ & $0,5(\mathbf{S})$ & $16(\mathbf{S})$ & $1(\mathbf{S})$ & $0,25(\mathbf{S})$ & $32(\mathbf{S})$ \\
\hline & & $32(\mathbf{R})$ & $2(\mathbf{S})$ & $<0,015$ (S) & 0,5 (S) & $2(\mathbf{S})$ & $1(\mathbf{S})$ & $0,25(\mathbf{S})$ & $32(\mathbf{S})$ \\
\hline \multirow{2}{*}{ Kitchen Knob } & \multirow{2}{*}{ Enterobacteriaceae spp. } & $64(\mathrm{R})$ & $2(\mathbf{S})$ & $<0,015(\mathbf{S})$ & $0,5(\mathbf{S})$ & $4(\mathrm{~S})$ & $0,5(\mathbf{S})$ & $0,25(\mathbf{S})$ & $16(\mathbf{S})$ \\
\hline & & $8(\mathbf{S})$ & $2(\mathbf{S})$ & $<0,015$ (S) & $1(\mathbf{S})$ & $2(\mathbf{S})$ & $1(\mathbf{S})$ & $0,25(\mathbf{S})$ & $16(\mathbf{S})$ \\
\hline \multirow{2}{*}{ Kitchen Tap } & Escherichia coli & $8(\mathbf{S})$ & $2(\mathbf{S})$ & $0,03(\mathbf{S})$ & $1(\mathbf{S})$ & $2(\mathbf{S})$ & $1(\mathbf{S})$ & $0,25(\mathbf{S})$ & $16(\mathbf{S})$ \\
\hline & Enterobacteriaceae spp. & $64(\mathbf{R})$ & $4(S)$ & $<0,015(\mathbf{S})$ & $1(\mathbf{S})$ & $2(\mathrm{~S})$ & $1(\mathbf{S})$ & $0,25(\mathbf{S})$ & $16(\mathbf{S})$ \\
\hline \multirow{2}{*}{ Kitchen Counter } & \multirow{2}{*}{ Enterobacteriaceae spp. } & $8(\mathbf{S})$ & $4(\mathrm{~S})$ & $<0,015(\mathbf{S})$ & $1(\mathbf{S})$ & $2(\mathbf{S})$ & $1(\mathrm{I})$ & $0,5(\mathbf{S})$ & $32(\mathbf{S})$ \\
\hline & & $8(\mathbf{S})$ & $4(\mathrm{~S})$ & $0,06(\mathbf{S})$ & $1(\mathbf{S})$ & $2(\mathrm{~S})$ & 1 (I) & $0,25(\mathbf{S})$ & $32(\mathbf{S})$ \\
\hline \multirow{2}{*}{ Cutting Board } & \multirow{2}{*}{$\begin{array}{c}\text { Escherichia coli } \\
\text { Enterobacteriaceae spp. }\end{array}$} & $128(\mathbf{R})$ & $8(\mathbf{S})$ & $0,06(\mathbf{S})$ & $0,5(\mathbf{S})$ & $2(\mathbf{S})$ & $4(\mathrm{~S})$ & $2(\mathbf{S})$ & $16(\mathbf{S})$ \\
\hline & & $128(\mathbf{R})$ & $8(\mathbf{S})$ & $0,125(\mathbf{S})$ & $1(\mathbf{S})$ & $2(\mathbf{S})$ & $4(S)$ & 2 (S) & $16(\mathbf{S})$ \\
\hline \multirow{2}{*}{ Refrigerator Handle } & \multirow{2}{*}{ Enterobacteriaceae spp. } & $8(\mathbf{S})$ & $2(\mathbf{S})$ & $<0,015(\mathbf{S})$ & $1(\mathbf{S})$ & $2(\mathbf{S})$ & $1(\mathbf{S})$ & $0,25(\mathbf{S})$ & $16(\mathbf{S})$ \\
\hline & & $8(\mathbf{S})$ & $2(\mathbf{S})$ & $<0,015$ (S) & $1(\mathbf{S})$ & $2(\mathbf{S})$ & $1(\mathbf{S})$ & $0,25(\mathbf{S})$ & $16(\mathbf{S})$ \\
\hline \multirow{2}{*}{ Stove Buttons } & \multirow{2}{*}{ Enterobacteriaceae spp. } & $8(\mathbf{S})$ & $2(\mathbf{S})$ & $<0,015(\mathbf{S})$ & $1(\mathbf{S})$ & $2(\mathbf{S})$ & $1(\mathbf{S})$ & $0,25(\mathbf{S})$ & $16(\mathbf{S})$ \\
\hline & & $64(\mathbf{R})$ & $2(\mathbf{S})$ & $0,03(\mathbf{S})$ & $1(\mathbf{S})$ & $2(\mathrm{~S})$ & $1(\mathbf{S})$ & $0,25(\mathbf{S})$ & $16(\mathbf{S})$ \\
\hline Kitchen Cloth & Escherichia coli & $256(\mathbf{R})$ & $4(\mathrm{~S})$ & $<0,015(\mathbf{S})$ & $1(\mathrm{~S})$ & $2(\mathbf{S})$ & $2(\mathbf{S})$ & $0,5(\mathbf{S})$ & $16(\mathbf{S})$ \\
\hline
\end{tabular}




\section{HOUSE 11}

\begin{tabular}{|c|c|c|c|c|c|c|c|c|c|}
\hline \multirow{2}{*}{ Local } & \multirow{2}{*}{ Microorganism } & \multicolumn{8}{|c|}{ Antibiotic MIC's $(\mu \mathrm{g} / \mathrm{mL})$ Breakpoints } \\
\hline & & AMP & $\mathrm{CHL}$ & CIP & GEN & NAL & TET & TMP & NIT \\
\hline \multirow{2}{*}{ Kitchen Tap } & Enterobacteriaceae spp. & $256(\mathbf{R})$ & $8(\mathbf{S})$ & $<0,015(\mathbf{S})$ & $0,5(\mathbf{S})$ & $8(\mathbf{S})$ & $1(\mathbf{S})$ & $0,25(\mathbf{S})$ & $32(\mathbf{S})$ \\
\hline & Salmonella spp. & $512(\mathbf{R})$ & $8(\mathbf{S})$ & $<0,015(\mathbf{S})$ & $1(\mathbf{S})$ & $8(\mathbf{S})$ & $1(\mathbf{S})$ & $0,25(\mathbf{S})$ & $32(\mathbf{S})$ \\
\hline \multirow{2}{*}{ Kitchen Counter } & Salmonella spp. & $8(\mathbf{S})$ & $4(\mathbf{S})$ & $<0,015(\mathbf{S})$ & $0,5(\mathbf{S})$ & $32(\mathbf{R})$ & $1(\mathbf{S})$ & $0,25(\mathbf{S})$ & $32(\mathbf{S})$ \\
\hline & Enterobacteriaceae spp. & $8(\mathbf{S})$ & $2(\mathrm{~S})$ & $<0,015$ (S) & $0,5(\mathbf{S})$ & $2(\mathbf{S})$ & $1(\mathrm{~S})$ & $0,25(\mathbf{S})$ & $64(\mathrm{I})$ \\
\hline \multirow{2}{*}{ Cutting Board } & \multirow{2}{*}{ Escherichia coli } & $16(\mathbf{I})$ & $4(\mathrm{~S})$ & $<0,015(\mathbf{S})$ & $1(\mathbf{S})$ & $2(\mathbf{S})$ & $1(\mathbf{S})$ & $0,5(\mathbf{S})$ & $64(\mathrm{I})$ \\
\hline & & $16(I)$ & $4(S)$ & $0,03(\mathbf{S})$ & $1(\mathbf{S})$ & $2(\mathbf{S})$ & $1(\mathbf{S})$ & $0,5(\mathbf{S})$ & 64 (I) \\
\hline \multirow{2}{*}{ Kitchen Cloth } & Escherichia coli & $16(\mathbf{I})$ & $4(\mathrm{~S})$ & $0,06(\mathbf{S})$ & $1(\mathbf{S})$ & $2(\mathbf{S})$ & $1(\mathbf{S})$ & $0,5(\mathbf{S})$ & $64(\mathrm{I})$ \\
\hline & Enterobacteriaceae spp. & $0,5(\mathbf{S})$ & $2(\mathbf{S})$ & $<0,015(\mathbf{S})$ & $0,5(\mathbf{S})$ & $2(\mathbf{S})$ & $1(\mathbf{S})$ & $0,5(\mathbf{S})$ & 64 (I) \\
\hline
\end{tabular}

\section{HOUSE 12}

\begin{tabular}{|c|c|c|c|c|c|c|c|c|c|}
\hline \multirow{2}{*}{ Local } & \multirow{2}{*}{ Microorganism } & \multicolumn{8}{|c|}{ Antibiotic MIC's $(\mu \mathrm{g} / \mathrm{mL})$ Breakpoints } \\
\hline & & AMP & CHL & CIP & GEN & NAL & TET & TMP & NIT \\
\hline & & $128(\mathbf{R})$ & $8(\mathbf{S})$ & $0,03(\mathbf{S})$ & $0,5(\mathbf{S})$ & $2(\mathbf{S})$ & $1(\mathbf{S})$ & $0,25(\mathbf{S})$ & $16(\mathbf{S})$ \\
\hline WC Tap & Enterobacteriaceae spp. & $128(\mathbf{R})$ & $4(\mathbf{S})$ & $0,03(\mathbf{S})$ & $0,5(\mathbf{S})$ & $2(\mathbf{S})$ & $1(\mathbf{S})$ & $0,25(\mathbf{S})$ & $16(\mathbf{S})$ \\
\hline & & $32(\mathbf{R})$ & $16(\mathbf{I})$ & $0,03(\mathbf{S})$ & $0,5(\mathbf{S})$ & $2(\mathbf{S})$ & $4(\mathbf{S})$ & $0,25(\mathbf{S})$ & $64(\mathbf{I})$ \\
\hline Kıtchen counter & Enterobacteriaceae spp. & $32(\mathbf{R})$ & $16(\mathbf{I})$ & $<0,015(\mathbf{S})$ & $0,5(\mathbf{S})$ & $2(\mathbf{S})$ & $4(\mathrm{~S})$ & 0,25 (S) & 64 (I) \\
\hline & & $1(\mathbf{S})$ & $8(\mathbf{S})$ & $<0,015(\mathbf{S})$ & $1(\mathrm{~S})$ & $2(\mathbf{S})$ & $4(\mathrm{~S})$ & $0,25(\mathbf{S})$ & $128(\mathbf{R})$ \\
\hline Kitchen cioth & Enterobacterlaceae spp. & $1(\mathrm{~S})$ & $8(\mathbf{S})$ & $<0,015$ (S) & $1(\mathrm{~S})$ & $2(\mathrm{~S})$ & $4(\mathrm{~S})$ & $0,25(\mathbf{S})$ & 64 (I) \\
\hline
\end{tabular}

\section{HOUSE 13}

\begin{tabular}{|c|c|c|c|c|c|c|c|c|c|}
\hline \multirow{2}{*}{ Local } & \multirow{2}{*}{ Microorganism } & \multicolumn{8}{|c|}{ Antibiotic MIC's $(\mu \mathrm{g} / \mathrm{mL})$ Breakpoints } \\
\hline & & AMP & CHL & CIP & GEN & NAL & TET & TMP & NIT \\
\hline & & $256(\mathbf{R})$ & $256(\mathbf{R})$ & $0,5(\mathbf{S})$ & $2(\mathbf{S})$ & $>512(\mathbf{R})$ & $256(\mathbf{R})$ & $0,125(\mathbf{S})$ & $16(\mathbf{S})$ \\
\hline Dishwasher Handle & Escherıchia colı & $8(\mathbf{S})$ & $8(\mathbf{S})$ & $0,125(\mathbf{S})$ & $1(\mathbf{S})$ & $4(\mathrm{~S})$ & $4(\mathrm{~S})$ & $0,5(\mathbf{S})$ & $16(\mathbf{S})$ \\
\hline Cutting Board & Enterobacteriaceae spp. & $0,5(\mathbf{S})$ & $2(\mathbf{S})$ & $<0,015(\mathbf{S})$ & $1(\mathbf{S})$ & $2(\mathbf{S})$ & $0,25(\mathbf{S})$ & $0,25(\mathbf{S})$ & $16(\mathbf{S})$ \\
\hline Kitchen Cloth & Escherichia coli & $512(\mathrm{R})$ & $256(\mathbf{R})$ & $0,5(\mathbf{S})$ & $1(\mathbf{S})$ & $>512(\mathbf{R})$ & $256(\mathbf{R})$ & $0,125(\mathbf{S})$ & $16(\mathbf{S})$ \\
\hline KItchen uloth & Eschericnia coil & $4(\mathrm{~S})$ & $8(\mathbf{S})$ & $0,125(\mathbf{S})$ & $1(\mathbf{S})$ & $>512(\mathrm{R})$ & $1(\mathbf{S})$ & $0,125(\mathbf{S})$ & $32(\mathbf{s})$ \\
\hline
\end{tabular}


HOUSE 14

\begin{tabular}{|c|c|c|c|c|c|c|c|c|c|}
\hline \multirow{2}{*}{ Local } & \multirow{2}{*}{ Microorganism } & \multicolumn{8}{|c|}{ Antibiotic MIC's ( $\mu \mathrm{g} / \mathrm{mL})$ Breakpoints } \\
\hline & & AMP & $\overline{\mathrm{CHL}}$ & CIP & GEN & NAL & TET & TMP & NIT \\
\hline Cutting Board & Escherichia coli & $32(\mathbf{R})$ & $8(\mathbf{S})$ & $0,03(\mathbf{S})$ & $1(\mathbf{S})$ & $2(\mathbf{S})$ & $2(\mathbf{S})$ & $0,5(\mathbf{S})$ & $32(\mathbf{S})$ \\
\hline Stove Buttons & Enterobacteriaceae spp. & $\begin{array}{l}4(\mathbf{S}) \\
16(\mathbf{I})\end{array}$ & $\begin{array}{l}2(\mathrm{~S}) \\
4(\mathrm{~S})\end{array}$ & $\begin{array}{c}<0,015(\mathbf{S}) \\
0,06(\mathbf{S})\end{array}$ & $\begin{array}{c}0,125(\mathbf{S}) \\
0,5(\mathbf{S})\end{array}$ & $\begin{array}{l}2(\mathrm{~S}) \\
4(\mathrm{~S})\end{array}$ & $\begin{array}{c}0,5(\mathbf{S}) \\
2(\mathbf{S})\end{array}$ & $\begin{array}{c}0,25(\mathbf{S}) \\
1(\mathbf{S})\end{array}$ & $\begin{array}{l}32(\mathbf{S}) \\
32(\mathbf{S})\end{array}$ \\
\hline Kitchen Cloth & Escherichia coli & $\begin{array}{l}256(\mathbf{R}) \\
256(\mathbf{R})\end{array}$ & $\begin{array}{l}2(\mathbf{S}) \\
2(\mathbf{S})\end{array}$ & $\begin{array}{l}<0,015(\mathbf{S}) \\
<0,015(\mathbf{S})\end{array}$ & $\begin{array}{l}1(\mathbf{S}) \\
1(\mathbf{S})\end{array}$ & $\begin{array}{l}4(\mathbf{S}) \\
4(\mathbf{S})\end{array}$ & $\begin{array}{c}0,5(\mathbf{S}) \\
0,5(\mathbf{S})\end{array}$ & $\begin{array}{l}0,5(\mathbf{S}) \\
0,5(\mathbf{S})\end{array}$ & $\begin{array}{l}16(\mathbf{S}) \\
16(\mathbf{S})\end{array}$ \\
\hline
\end{tabular}

HOUSE 15

\begin{tabular}{|c|c|c|c|c|c|c|c|c|c|}
\hline \multirow{2}{*}{ Local } & \multirow{2}{*}{ Microorganism } & \multicolumn{8}{|c|}{ Antibiotic MIC's ( $\mu \mathrm{g} / \mathrm{mL})$ Breakpoints } \\
\hline & & AMP & $\mathbf{C H L}$ & CIP & GEN & NAL & TET & TMP & NIT \\
\hline \multirow{2}{*}{$\begin{array}{c}\text { Domestic Animal } \\
\text { (Dog) }\end{array}$} & \multirow{2}{*}{ Escherichia coli } & $0,5(\mathbf{S})$ & $1(\mathbf{S})$ & $<0,015(\mathbf{S})$ & $0,5(\mathbf{S})$ & $2(\mathbf{S})$ & $0,5(\mathbf{S})$ & $0,25(\mathbf{S})$ & $32(\mathbf{S})$ \\
\hline & & $2(\mathbf{S})$ & $4(S)$ & $<0,015$ (S) & $0,5(\mathbf{S})$ & $4(\mathrm{~S})$ & $2(\mathbf{S})$ & 0,25 (S) & $16(\mathbf{S})$ \\
\hline \multirow{2}{*}{ WC Tap } & \multirow{2}{*}{ Escherichia coli } & $1(\mathbf{S})$ & $2(\mathbf{S})$ & $<0,015(\mathbf{S})$ & $0,5(\mathbf{S})$ & $2(\mathbf{S})$ & $0,5(\mathbf{S})$ & $0,5(\mathbf{S})$ & $32(\mathbf{S})$ \\
\hline & & $1(\mathbf{S})$ & $2(\mathbf{S})$ & $<0,015$ (S) & $0,5(\mathbf{S})$ & $2(\mathrm{~S})$ & 0,5 (S) & $0,5(\mathbf{S})$ & $32(\mathbf{S})$ \\
\hline \multirow{2}{*}{ Kitchen Knob } & \multirow{2}{*}{ Escherichia coli } & $1(\mathbf{S})$ & $2(\mathbf{S})$ & $<0,015(\mathbf{S})$ & $0,5(\mathbf{S})$ & $2(\mathbf{S})$ & $0,5(\mathbf{S})$ & $0,5(\mathbf{S})$ & $32(\mathbf{S})$ \\
\hline & & $1(\mathbf{S})$ & $2(\mathbf{S})$ & $<0,015$ (S) & 0,5 (S) & $2(\mathbf{S})$ & $0,5(\mathbf{S})$ & $0,5(\mathbf{S})$ & $32(\mathbf{S})$ \\
\hline \multirow{2}{*}{ Kitchen Tap } & Enterobacteriaceae spp. & $1(\mathbf{S})$ & $4(\mathrm{~S})$ & $<0,015(\mathbf{S})$ & $1(\mathbf{S})$ & $4(\mathrm{~S})$ & $0,5(\mathbf{S})$ & $0,25(\mathbf{S})$ & $32(\mathbf{S})$ \\
\hline & Escherichia coli & $8(\mathbf{S})$ & $4(\mathrm{~S})$ & $<0,015$ (S) & $0,5(\mathbf{S})$ & $4(\mathrm{~S})$ & $0,5(\mathbf{S})$ & $0,25(\mathbf{S})$ & $32(\mathbf{S})$ \\
\hline \multirow{2}{*}{ Kitchen Counter } & \multirow{2}{*}{ Escherichia coli } & $\overline{128(\mathbf{R})}$ & $4(\mathrm{~S})$ & $<0,015(\mathbf{S})$ & $1(\mathbf{S})$ & $1(\mathbf{S})$ & $0,5(\mathbf{S})$ & $0,5(\mathbf{S})$ & $128(\mathrm{R})$ \\
\hline & & $128(\mathbf{R})$ & $2(\mathbf{S})$ & $<0,015$ (S) & $0,5(\mathbf{S})$ & $1(\mathbf{S})$ & $0,5(\mathbf{S})$ & $0,25(\mathbf{S})$ & $16(\mathbf{S})$ \\
\hline \multirow{2}{*}{ Refrigerator Handle } & \multirow{2}{*}{ Enterobacteriaceae spp. } & $16(\mathrm{I})$ & $4(\mathrm{~S})$ & $<0,015(\mathbf{S})$ & $0,5(\mathbf{S})$ & $2(\mathbf{S})$ & $0,5(\mathbf{S})$ & $0,5(\mathbf{S})$ & $16(\mathbf{S})$ \\
\hline & & $8(\mathbf{S})$ & $4(\mathrm{~S})$ & $<0,015$ (S) & $0,5(\mathbf{S})$ & $4(\mathrm{~S})$ & $0,5(\mathbf{S})$ & $0,5(\mathbf{S})$ & $16(\mathbf{S})$ \\
\hline \multirow{2}{*}{ Stove Buttons } & Escherichia coli & $64(\mathrm{R})$ & $2(\mathbf{S})$ & $<0,015(\mathbf{S})$ & $1(\mathbf{S})$ & $4(\mathrm{~S})$ & $16(\mathbf{R})$ & $0,5(\mathbf{S})$ & $32(\mathbf{S})$ \\
\hline & Enterobacteriaceae spp. & $32(\mathbf{R})$ & $4(\mathrm{~S})$ & $0,03(\mathbf{S})$ & $1(\mathbf{S})$ & $4(\mathrm{~S})$ & $2(\mathbf{S})$ & $0,25(\mathbf{S})$ & $16(\mathbf{S})$ \\
\hline \multirow{2}{*}{ Dishwasher Handle } & \multirow{2}{*}{ Escherichia coli } & $0,5(\mathbf{S})$ & $1(\mathrm{~S})$ & $<0,015(\mathbf{S})$ & $0,5(\mathbf{S})$ & $2(\mathbf{S})$ & $0,5(\mathbf{S})$ & $0,5(\mathbf{S})$ & $32(\mathbf{S})$ \\
\hline & & $4(\mathrm{~S})$ & $4(\mathrm{~S})$ & $<0,015(\mathbf{S})$ & $0,5(\mathbf{S})$ & $2(\mathrm{~S})$ & $0,5(\mathbf{S})$ & $0,5(\mathbf{S})$ & $32(\mathbf{S})$ \\
\hline \multirow{2}{*}{ Kitchen Cloth } & \multirow{2}{*}{ Enterobacteriaceae spp. } & $32(\mathbf{R})$ & $4(\mathrm{~S})$ & $<0,015(\mathbf{S})$ & $0,5(\mathbf{S})$ & $4(\mathrm{~S})$ & $1(\mathbf{S})$ & $0,5(\mathbf{S})$ & $128(\mathbf{R})$ \\
\hline & & $8(\mathbf{S})$ & $2(\mathbf{S})$ & $<0,015(\mathbf{S})$ & $0,5(\mathbf{S})$ & $2(\mathbf{S})$ & $0,5(\mathbf{S})$ & $0,25(\mathbf{S})$ & $16(\mathbf{S})$ \\
\hline
\end{tabular}

